\title{
THE MAKING OF THE SECOND ENGLISH CORONATION ORDO
}

\author{
DAVID PRATT
}

\begin{abstract}
This article reassesses the Second English Coronation Ordo in the light of its relationship to Carolingian sources. The dependence of the Ordo on a distinctive West Frankish source, here termed the Leiden Ordo, has many implications since the Leiden Ordo seems likely to have been composed for the anointing of Charles the Straightforward by Fulk of Rheims in January 893. This finding provides a probable context for the importing of West Frankish ordines in King Alfred's dealings with Rheims. It also strengthens the case for placing the Second Ordo in the mid or late 890s, rather than early in Æthelstan's reign. Anointing practices were directly implicated in the 'crisis of authority' affecting the Carolingian world in the late ninth century. The new understanding of the Second Ordo adds a further dimension to King Alfred's efforts to promote the 'kingdom of the Anglo-Saxons', and has wider implications for the development of royal ordines in western Europe.
\end{abstract}

An important question, with a bearing on political ideas and cross-Channel contact in the later Anglo-Saxon period, concerns the dating of the liturgical text known as the Second English Coronation Ordo. The text has a pivotal position in the development of the English anointing rite. ${ }^{1}$ The seminal work of Janet Nelson placed the understanding of the late Anglo-Saxon coronation service on new foundations. Firstly, her study of the Ordo in the Leofric Missal (Oxford, Bodleian Library, Bodley 579) revealed this text to be of probable English origin, and thus rightly identified as the First English $O r d o .^{2}$ Secondly, Nelson disentangled the complex record of the Second English Ordo, establishing the priority of the A-version, represented by the Sacramentary of Ratold and by a large group of Continental manuscripts. ${ }^{3}$ The A-version should be distinguished from the later B-version, transmitted in a number of

1 Ordines Coronationis Franciae: Texts and Ordines for the Coronation of Frankish and French Kings and Queens in the Middle Ages, ed. R. A. Jackson, 2 vols. (Philadelphia, PA, 1995-2000), pp. 168-200. The present article is intended to complement D. Pratt, English Coronation Ordines in the Ninth and Early Tenth Centuries (forthcoming), containing new editions, with parallel English translation, of the First Ordo and the A-version of the Second Ordo. The former is a full diplomatic edition; that of the A-version of the Second Ordo employs the Sacramentary of Ratold as a base text, and aligns it alongside the probable sources for each formula. The article arises from the need to combine the investigation of certain issues of transmission with wider historical enquiry, in order to develop findings beyond the scope of the forthcoming edition.

2 J. L. Nelson, 'The Earliest Surviving Royal Ordo: Some Liturgical and Historical Aspects', in her Politics and Ritual in Early Medieval Europe (London, 1986), pp. 341-60; The Leofric Missal, ed. N. Orchard, HBS 11314 (London, 2002) II, 429-39.

3 J. L. Nelson, 'The Second English Ordo', in her Politics and Ritual, pp. 361-74, at 361-9; The Sacramentary of Ratoldus (Paris, Bibliothèque nationale de France, lat. 12052), ed. N. Orchard, HBS 116 (London, 2005), 47-58. 
later tenth- and eleventh-century English pontificals. ${ }^{4}$ The B-version represented an important revision of the Second Ordo, probably redacted in the mid tenth century, and would prove influential in the longer history of the English anointing ritual. ${ }^{5}$ Elements of it were combined with formulas derived from the Romano-Germanic Pontifical to create the Third Recension, characteristic of twelfth- and thirteenth-century pontificals, the origins of which have been subject to debate. ${ }^{6}$ In the early fourteenth century, the Third Recension was substantially revised in the light of the B-version of the Second Ordo, and with recourse to Continental sources aligned with the B-version, to form the Fourth Recension. ${ }^{7}$ Subsequently consolidated in the Liber regalis of the late fourteenth century, the Fourth Recension would provide the basis for later medieval and early modern coronations before $1689 .{ }^{8}$

Exploring the development of the Second Ordo, Nelson also showed the significance of the anointing prayer, Omnipotens sempiterne deus, for the understanding of the A-version. ${ }^{9}$ The relevant readings are available in the Appendix. ${ }^{10}$ Whereas the Sacramentary of Ratold specified the regnum [...] albionis totius, implying kingship of all Britain, the remaining manuscripts made reference to the regale solium uidelicet saxonum merciorum nordhanhimbrorumque sceptra ('the royal throne namely the sceptres of the Saxons, Mercians and Northumbrians'), describing kingship over the English. Yet transmitted forms of the text implied an earlier reading, not directly preserved. The word pariter ('equally'), together with the phrase utrorumque horum populorum ('of both these peoples'), and the hope that the king might 'establish and govern the apex of paternal glory unitedly', indicated that the original reference in the A-version had been to kingship of two peoples, as preserved by the readings of the B-version: namely, regnum anglorum uel saxonum pariter ('the kingdom of the Angles or Saxons equally') and regale solium uidelicet anglorum uel

\footnotetext{
${ }^{4}$ Nelson, 'The Second English Ordo', pp. 363 and 365. Ptd in English Coronation Records, ed. L. G. Wickham Legg (Westminster, 1901), pp. 15-23 (from CCCC 146); The Claudius Pontificals (from Cotton MS. Claudius A. iii in the British Museum), ed. D. H. Turner, HBS 117 (London, 1971), 89-97.

5 Nelson, 'The Second English Ordo', pp. 369-74.

6 J. Brückmann, 'The Ordines of the Third Recension of the Medieval Coronation Order', Essays in Medieval History presented to Bertie Wilkinson, ed. T. A. Sandquist and M. R. Powicke (Toronto, 10969), pp. 98-115. For the suggestion that the Third Ordo had been compiled in the mid eleventh-century, and used for the coronations of Harold and William I, see J. L. Nelson, 'The Rites of the Conqueror', in her Politics and Ritual, pp. 375-401. For doubts over this hypothesis, see G. Garnett, 'The Third Recension of the English Coronation Ordo: the Manuscripts', HSJ 11 (2003), 43-71. For the Romano-Germanic Pontifical, see below, p. $00 / 21$, n. 139.

7 P. L. Ward, 'The Coronation Ceremony in Mediaeval England', Speculum 14 (1939), 160-78, at 177-8; H. G. Richardson, 'The Coronation in Medieval England: the Evolution of the Office and the Oath', Traditio 91 (1961), 111-202, at 136-50; A. Hughes, 'The Origins and Descent of the Fourth Recension of the English Coronation', Coronations: Medieval and Early Modern Monarchic Ritual, ed. J. M. Bak (Berkeley, CA, 1990), pp. 197-216.

8 H. A. Wilson, 'The English Coronation Orders', JTS 2 (1901), 481-504, at 491-504; English Coronation Records, ed. Wickham Legg, pp. xv-lxiii and 81-316.

${ }^{9}$ Nelson, 'The Second English Ordo', pp. 363-5.

10 See below, pp. 00-00/83-92.
} 
saxonum sceptra ('the royal throne namely the sceptres of the Angles or Saxons'). ${ }^{11}$ The earliest version of the Second Ordo had represented the ruler as 'king of the Anglo-Saxons', a point of some importance. For the related titles rex Anglorum [et] Saxonum, rex Angulsaxonum and rex Anglo Saxonum, have been shown by Simon Keynes to have specific implications in diplomas of the late ninth and early tenth century, denoting the kingdom formed c. 880 under King Alfred, through the extension of his rule to western Mercia, combining the 'Saxon' West Saxon kingdom, and its south-eastern regions, with 'Anglian' Mercia. ${ }^{12}$ The title was inherited by Edward the Elder and also found use in diplomas early in Æthelstan's reign, prior to his takeover of Northumbria in 927, after which he was styled rex Anglorum. ${ }^{13}$ These considerations give the outer limits 880 x 925 for the compilation of the Second Ordo, suggesting a context also for the 'Albion' and 'SMN' readings in the middle decades of the tenth century. ${ }^{14}$

The key question is whether the drafting of the Second Ordo might be dated more closely. The issue is important, since the Second Ordo amounted to a major redrafting of the anointing rite. The First Ordo provided the basic framework, which was expanded with prayers principally drawn from two West Frankish ordines. ${ }^{15}$ The English rite thus fell under the influence of the rich West Frankish tradition of anointing, in which the theorizing and liturgical inventiveness of Hincmar, archbishop of Rheims, played a formative role. ${ }^{16}$ In addition to the new anointing prayer, the items of regalia were altered and expanded; the rite also acquired a new prayer of enthronement, while two further additions suggest deeper changes in the representation of kingship. ${ }^{17}$ Within a new set of preliminaries, the king now issued a formal promise to the bishops of his kingdom, vowing to preserve 'canonical privilege and due law and justice'. ${ }^{18}$ Dependent on Hincmarian procedure, the promise

\footnotetext{
11 Nelson, 'The Second English Ordo', pp. 364-5.

12 S. Keynes, 'King Alfred and the Mercians', Kings, Currency and Alliances: History and Coinage of Southern England in the Ninth Century, ed. M. A. S. Blackburn and D. N. Dumville (Woodbridge, 1998), pp. 1-45, at 25-9, cf. 34-45.

13 S. Keynes, 'Edward, King of the Anglo-Saxons', Edward the Elder 899-924, ed. N. J. Higham and D. H. Hill (London, 2001), pp. 40-66, at 48-51, cf. 57-62; idem, 'England, c. 900-1016', The New Cambridge Medieval History, III: c.900-c.1024, ed. T. Reuter (Cambridge, 1999), 456-84, at 462-4 and 468.

14 Nelson, 'The Second English Ordo', pp. 368-9.

15 Ibid., pp. 361-2.

16 J. L. Nelson, 'Kingship, Law and Liturgy in the Political Thought of Hincmar of Rheims', in her Politics and Ritual, pp. 133-71; ibid., 'The Lord's Anointed and the People's Choice: Carolingian Royal Ritual', in her The Frankish World 750-900 (London, 1996), pp. 99-131, at 117-119. See also C. A. Bouman, Sacring and Crowning: the Development of the Latin Ritual for the Anointing of Kings and the Coronation of an Emperor before the Eleventh Century (Groningen, 1957), pp. 17-20, 115-21, 133, 151 and 157-8.

17 The overall structure of the A-version of the Second Ordo is laid out in the Appendix: see below, pp. 0000/102-5.

18 'Promitto uobis et perdono quia unicuique de uobis et ecclesiis uobis commissis, canonicum priuilegium et debitam legem atque iustitiam seruabo, et defensionem quantum potuero adiuuante domino exibebo, sicut rex in suo regno, unicuique episcopo et ecclaesiae sibi commissae per rectum exibere debet' ('I promise to you and grant that I will preserve for each of you and for the churches entrusted to you, canonical privilege and due law and justice, and that I will maintain protection as much as I am able with the Lord's assistance, just as
} 
introduced a new element of conditionality into the ritual, representing the king's anointing as formally conditional on this initial promise. ${ }^{19}$ Moreover, whereas the First Ordo had concerned the king only, the Second Ordo now incorporated a queen's ordo, also of West Frankish derivation. ${ }^{20}$ Since there are reasons for thinking that, prior to the Second Ordo, West Saxon consorts had not routinely been anointed, the change appears to have related to the broader rethinking of queenly status in later Anglo-Saxon England. ${ }^{21}$

Existing arguments have presented two candidates for the first king to be anointed using the Second Ordo: Edward the Elder and Æthelstan. Nelson initially favoured Edward the Elder, postulating that the Ordo had been compiled in the latter part of King Alfred's reign. The rulership over Angles and Saxons suggested connections with Alfred's political achievement, while the inclusion of a queen's ordo pointed towards Edward. ${ }^{22}$ Nelson's case for Edward the Elder has found favour with Keynes, since it appears to harmonize with the broader understanding of the 'kingdom of the Anglo-Saxons'; liturgical commentators have tended to leave the matter open. ${ }^{23}$ More recently, however, Nelson has presented a revised case for Æthelstan, in arguments dependent on the new edition of the Leofric Missal by Nicholas Orchard, who has argued that the core of this controversial manuscript may have been written around the year 900 for Plegmund, archbishop of Canterbury (890-923). ${ }^{24}$ Inferring on this basis that the First Ordo remained current in the early tenth century, Nelson has suggested a context for the Second Ordo in the aftermath of Æthelstan's troubled accession. ${ }^{25}$ Attempts to contextualize the Second Ordo have therefore depended on a number of considerations upon which arguments have been built: principally, the representation of kingship over two peoples. the treatment of queenship, and the manuscript transmission of the First Ordo.

All of these issues remain important, yet there is a further feature of the Second Ordo which has been under-explored: namely, its relationship to the West Frankish tradition of anointing. The apparent dependence of the Second Ordo on two West Frankish ordines, the Erdmann Ordo and the Ordo of Seven Forms, has been widely recognized, but the

a king should in his kingdom rightly maintain protection for each bishop and for the church entrusted to him'): Sacramentary of Ratoldus, ed. Orchard, pp. 47-8.

19 Cf. Erdmann Ordo 3 (Ordines, ed. Jackson, pp. 147). For Hincmar's development of the royal promissio, first explicit in the Ordo for the anointing of Louis the Stammerer in 877, see Nelson, 'Kingship, Law and Liturgy', pp. 149-52. Cf. also Bouman, Sacring and Crowning, pp. 141-5.

20 Sacramentary of Ratoldus, ed. Orchard, pp. 55-6. Cf. Erdmannn Ordo 23-32 (Ordines, ed. Jackson, pp. 1512).

21 See below, pp. 00-00/13-14 and 65-70..

22 Nelson, 'The Second English Ordo', pp. 365-7.

23 Keynes, 'Edward, King of the Anglo-Saxons', pp. 48-9. Cf. Jackson, Ordines, p. 29; Orchard, Sacramentary of Ratoldus, pp. cxxix-cxxxiv.

24 J. L. Nelson, 'The First Use of the Second Anglo-Saxon Ordo', Myth, Rulership, Church and Charters: Essays in honour of Nicholas Brooks, ed. J. Barrow and A. Wareham (Aldershot, 2008), pp. 117-26; Orchard, Leofric Missal, pp. 1-131.

25 Nelson, 'The First Use of the Second Anglo-Saxon Ordo', pp. 123-5. 
chronological implications have remained uncertain. Richard Jackson's exemplary edition of West Frankish coronation ordines provides a new basis for enquiry. ${ }^{26}$ While the Erdmann Ordo may be placed with some confidence in the late ninth century, the Ordo of Seven Forms is less well understood. ${ }^{27}$ The matter is complicated by the fact that the Ordo of Seven Forms survives in two versions: in addition to the main, fuller version of the text, there is also a shorter version in a Leiden manuscript, first identified by Guy Lanoé, and here termed the Leiden Ordo. ${ }^{28}$ The Leiden Ordo poses problems for the understanding of the Second Ordo, for which dependence on the Ordo of Seven Forms has generally been assumed. Firstly, when compared with the Ordo of Seven Forms, the Leiden Ordo is in various respects closer to the readings of the Second Ordo, raising new questions over the nature of the relationship between the three ordines. ${ }^{29}$ Secondly, in a troubling crux, the Leiden Ordo itself makes provision for the king ruling over two peoples, employing the same words as the Second Ordo ('pariter', 'utrorumque horum populorum'), yet in this case with reference to the 'Franks and Aquitanians'. ${ }^{30}$ These features complicate the understanding of textual development.

The purpose of this article is to address the question of the contextualization of the Second Ordo by taking account of its relationship to sources. The article thus pursues matters of transmission in so far as they contribute to a wider historical enquiry concerning the date of the Second Ordo, offering insight into the probable context for these important developments in royal ritual. The article builds a case, based on a combination of considerations relating to transmission, cross-Channel contacts and political context, for locating the Second Ordo in the latter part of Alfred's reign. Since Nelson's analysis of the different versions of the Second Ordo understandably did not take account of the Leiden Ordo, the article opens with a reassessment of the inter-relationship and relative chronology of the early English ordines. The view that the Second Ordo had superseded the First Ordo appears robust; the notion that 'Leofric A' had been produced for Plegmund is shown to be problematic, having no bearing on the issue of dating. The article's arguments assigning the Second Ordo to Alfred's reign proceed from a resolution of the textual problems arising from the Leiden Ordo, allowing it to be identified as one of the sources used by the compiler of the

\footnotetext{
26 Ordines, ed. Jackson, esp. pp. 73-200, for Ordines pertinent to the Anglo-Saxon sequence.

27 Jackson, Ordines, pp. 154, cf. 27-8; J. L. Nelson, 'The First Use of the Second Anglo-Saxon Ordo', p. 123. See also idem, 'Early Medieval Rites of Queen-Making and the Shaping of Medieval Queenship', in her Rulers and Ruling Families in Early Medieval Europe: Alfred, Charles the Bald, and Others (Aldershot, 1999), no. XV, pp. 301-15, at 311-12. I follow Janet Nelson in preferring Seven Forms, as the established name for this Ordo, over Jackson's suggestion, Eleven Forms. For the Erdmann Ordo, see below, pp. 00$00 / 23-5$.

28 G. Lanoè, 'L'ordo de couronnement de Charles le Chauve à Sainte-Croix d'Orléans (6 juin 848)', Kings and Kingship in Medieval Europe, ed. A. J. Duggan (London, 1993), pp. 41-68. Cf. Jackson, Ordines, pp. 28-9 and 155-6.

${ }^{29}$ See below, pp. 00-00/28-32.

30 The relevant texts are laid out in the Appendix: see below, pp. 00-00/93-101.
} 
Second Ordo. The analysis has implications for the Leiden Ordo, enabling the case to be made for identifying it as the rite used for the anointing of Charles the Straightforward in January 893. Central to the configuration of West Frankish politics in the late ninth century, Charles's anointing was conducted by Fulk, archbishop of Rheims, with whom the Leiden Ordo may be associated. The case for regarding the Second Ordo as Alfredian depends on three broadly developed considerations. Firstly, Alfred's dealings with Rheims, St-Bertin and Flanders provide an attractive context within which the importing of the Leiden Ordo might be situated. Secondly, there are objections to the scenario suggested by Nelson for the drafting of Second Ordo, early in Æthelstan's reign. The evidence of Æthelstan's coinage sometimes cited as indicating a change of regalia in his reign - is shown to be compatible with the proposed Alfredian dating. Thirdly, the content of the Second Ordo would accord strongly with the political and dynastic context late in Alfred's reign. The probable identification of the Second Ordo as Alfredian adds a further dimension the understanding of Alfred's efforts to promote the 'kingdom of the Anglo-Saxons, implying a concerted dynastic strategy which aimed to preserve the kingdom intact. A role for Grimbald of St-Bertin in the compiling of the Second Ordo may be suspected. There are implications also for the English use of West Frankish ideas and practices relating to anointing, and for important changes concerning queenship.

\section{THE SECOND ORDO AND THE LITURGY OF ROYAL ANOINTING IN ANGLO-SAXON ENGLAND}

The Second Ordo should be approached as part of the sequence of pre-Conquest English royal ordines. The Anglo-Saxon ordines are of great value in a European context since anointing practices have often been regarded as having been led by Frankish example and precedent. ${ }^{31}$ Although Hincmar's theorizing and agency would prove deeply influential, there may be a danger of over-extrapolating from later ninth-century developments. As Nelson showed, the First English Ordo gives access to practices distinct from Frankish ones, and indicates a political culture in which, probably from as early as the late eighth century, the anointing of kings by bishops was well known. ${ }^{32}$ This contrasts with the Frankish world in the late eighth and early ninth century, where anointing by popes was the more usual practice. ${ }^{33}$ As Nelson has argued, anointing by bishops became common from the mid ninth

\footnotetext{
31 P. E. Schramm, 'Die Krönung bei den Angelsachsen', in his Kaiser, Könige und Papste: gesammelte Aufsätze zur Geschichte des Mittelalters, 4 vols. (Stuttgart, 1968-71) II, 169-207; Bouman, Sacring and Crowning, pp. 152-4 and 156-8; J. M. Wallace-Hadrill, 'Charlemagne and England', in his Early Medieval History (Oxford, 1975), pp. 154-80, at 158-9.

32 Nelson, 'The Earliest Surviving Royal Ordo', esp. pp. 352-3 and 359-60.

33 Ibid., p. 352; Nelson, 'The Lord's Anointed and the People's Choice', pp. 102-3 and 110-11.
} 
century onwards, one of several ways in which king-making fell under the increasing influence of Frankish ecclesiastics. ${ }^{34}$

Another feature is the degree of development suggested by the Anglo-Saxon sequence. Inevitably, one faces many problems in relating specific forms of ordo to historical instances of anointing. 35 Transmitted ordines are imperfect as a guide to performance, and, even in the case of a pontifical credibly associated with a specific archbishop, there has to be uncertainty whether the ordo so preserved would accurately represent an anointing performed by the book's owner. ${ }^{36}$ While arguments may be advanced for the use of particular ordines at known anointings, there would be dangers in assuming that all variant versions of an ordo should be explained by considerations of intended use. ${ }^{37}$ The emergence in the same period of the pontifical as a form of liturgical manual indicates that allowances should be made for other dynamics, such as standardization, inventorization or cross-fertilization in the transmission of ordines. ${ }^{38}$ For the main ordines in the Anglo-Saxon sequence, nevertheless, there are strong grounds for thinking that each related to the current ritual of anointing. The Anglo-Saxon period contrasts with the later medieval and early modern history of the English anointing ritual, characterized by great stability in the liturgical form of the rite. ${ }^{39}$ In response to a variety of pressures, the Anglo-Saxon anointing ritual was more dynamic and fluid, a form of liturgy capable of being expanded and reworked.

34 Nelson, 'The Lord's Anointed and the People's Choice', pp. 103 and 114-20; cf. also D. Pratt, The Political Thought of King Alfred the Great (Cambridge, 2007), pp. 58-60 and 72-3.

35 Bouman, Sacring and Crowning, pp. 50-89; J. L. Nelson, 'Ritual and Reality in the Early Medieval Ordines', in her Politics and Ritual, pp. 329-39; Jackson, Ordines, pp. 21-38.

36 It is clear from the letter of Hincmar of Rheims to Adventius of Metz (c. 869) that an episcopal ordination might be conducted using a separate rotula, which probably contained the liturgical formulas only, without rubrics: M. Andrieu, 'Le Sacre épiscopal d'après Hincmar de Reims', Revue d'histoire écclesiastique 48 (1953), 22-73, at 24 and 36-7; Bouman, Sacring and Crowning, pp. 71 and 75; Nelson, 'The Earliest Surviving Royal Ordo', p. 354. Royal ordines could also circulate separately: for a now lost Liège manuscript once containing four Hincmarian ordines, see below, p. 00/36.

37 Bouman, Sacring and Crowning, pp. 53, 81-2 and 85.

38 Ibid., pp. 52-8, 71-82 and 85-9. For the development of the pontifical, see N. K. Rasmussen, Les Pontificaux du haut moyen âge: Genèse du livre de l'évêque, ed. M. Haverals, Spicilegium Sacrum Lovaniense, Études et Documents 49 (Leuven, 1998); D. N. Dumville, Liturgy and the Ecclesiastical History of Late Anglo-Saxon England (Woodbridge, 1992), pp. 66-95; J. L. Nelson and R. W. Pfaff, 'Pontificals and Benedictionals', The Liturgical Books of Anglo-Saxon England, ed. R. W. Pfaff, OEN Subsidia 23 (1995), 87-98; S. Hamilton, 'The Early Pontificals: the Anglo-Saxon Evidence Reconsidered from a Continental Perspective', England and the Continent in the Tenth Century: Studies in honour of Wilhelm Levison (1876-1947), ed. D. Rollason, C. Leyser and H. Williams (Turnhout, 2010), pp. 411-28; H. Parkes, The Making of Liturgy in the Ottonian Church: Books, Music and Ritual in Mainz, 950-1050 (Cambridge, 2015), pp. 158-60 and 174-80.

39 Such stablity arose from the longevity of the Fourth Recension of the English Ordo, in use from the coronation of Edward II (1308) and consolidated in the Liber regalis of the late fourteenth century (London, Westminster Abbey MS 38), from which early modern forms of the rite, before 1689, were closely derived: Wilson, 'The English Coronation Orders', pp. 491-504; English Coronation Records, ed. Wickham Legg, pp. xv-lxiii and 81-316. See D. J. Sturdy, "Continuity" versus "Change": Historians and English Coronations of the Medieval and Early Modern Periods', Coronations: Medieval and Early Modern Monarchic Ritual, ed. J. M. Bak (Berkeley, CA, 1990), pp. 228-45. For the Fourth Recension, see above, p. 00/2, n. 7. 


\section{The First Ordo}

The centrality of the Second Ordo within the Anglo-Saxon sequence may be shown by comparison with the First Ordo. There are three principal manuscripts, of which the earliest, Oxford, Bodleian Library, Bodley 579, known as the Leofric Missal, poses major problems. ${ }^{40}$ The First Ordo occurs in the core of the manuscript, known as 'Leofric A', a combined sacramentary and pontifical written in a Continental Caroline minuscule of the second half of the ninth century showing strong Insular influences. ${ }^{41}$ Two later manuscripts contain the First Ordo in a form which differs slightly from the Leofric version, and includes a set of rubrics, for which an early origin is suspected. ${ }^{42}$ Rouen, Bibliothèque municipale, MS A.27 (368), known as the Lanalet Pontifical, is an early eleventh-century pontifical and benedictional of West Country origin. ${ }^{43}$ An early note on an added leaf, attributing the book's ownership to 'Lyfinc bisceop', may be best interpreted as a reference to Lyfing, bishop of Wells (998/91013) and archbishop of Canterbury (1013-20), indicating that the book had been at Wells early in its history. ${ }^{44}$ Paris, Bibliothèque nationale de France, lat. 10575, known as the Ecgberht Pontifical, is a combined pontifical and benedictional written $c$. 1000, probably produced at Worcester. 45

As Nelson has shown, the firmest arguments for the English origin of the First Ordo hinge on the relationship to the ordo used for the anointing of Charles the Bald's daughter, Judith, following her marriage to King Æthelwulf in 856. ${ }^{46}$ Hincmar's drafting of an ordo for Judith makes sense in the light of Charles's own anointing as king of Aquitaine in 848, and

${ }^{40}$ H. Gneuss, Handlist of Anglo-Saxon Manuscripts: a List of Manuscripts and Manuscript Fragments Written or Owned in England up to 1100 (Tempe, AZ, 2001), no. 585; N. R. Ker, Catalogue of Manuscripts Containing Anglo-Saxon, Reissue with Supplement (Oxford, 1990), pp. 378-9 (no. 315); E. Temple, AngloSaxon Manuscripts 900-1066 (London, 1976), pp. 44-5 (no. 17); K. D. Hartzell, Catalogue of Manuscripts Written or Owned in England up to 1200 Containing Music (Woodbridge, 2006), pp. 400-27 (no. 260).

41 D. N. Dumville, 'On the Dating of Some Late Anglo-Saxon Liturgical Manuscripts', Trans. of the Cambridge Bibliographical Soc. 10 (1996 for 1991-5), 40-57, at 50; idem, Liturgy, pp. 39-43 and 82.

42 Nelson, 'The Earliest Surviving Royal Ordo', pp. 353-9. The 'Ecgberht-Lanalet' version of the First Ordo has been inadequately served by editors; the edition of Wickham Legg (English Coronation Records, pp. 3-9) is selective in the recording of variants. The text of the Ecgbert Pontifical suffers from textual corruption; the text of the superior manuscript, the Lanalet Pontifical, used as a base text by Wickham Legg, is available in incomplete form in Pontificale Lanaletense (Bibliothèque de la Ville de Rouen A. 27 Cat. 368), ed. G. H. Doble, HBS 74 (London, 1937), 59-63. The 'Ecgberht-Lanalet' version is cited below from Doble, adjusted where necessary in the light of Nelson's comments, pending the new edition in Pratt, English Coronation Ordines.

43 Gneuss, Handlist, no. 922; Ker, Catalogue, pp. 447-8 (no. 374); Temple, Anglo-Saxon Manuscripts, p. 106 (no. 90); Hartzell, Catalogue, pp. 538-57 (no. 318); Pontificale Lanaletense, ed. Doble.

44 Dumville, 'On the Dating', pp. 51-2; P. A. Stokes, English Vernacular Minuscule from AEthelred to Cnut c.990-c.1035 (Cambridge, 2014), pp. 55-7; Pratt, English Coronation Ordines.

45 Gneuss, Handlist, no. 896; Ker, Catalogue, pp. 441-2 (no. 370); Hartzell, Catalogue, pp. 528-35 (no. 312); Two Anglo-Saxon Pontificals (the Egbert and Sidney Sussex Pontificals), ed. H. M. J. Banting, HBS 104 (London, 1989). For the book's origins, see D. N. Dumville, 'Anglo-Saxon Books: Treasure in Norman Hands', ANS 16 (1994), 83-99, at 95; Stokes, English Vernacular Minuscule, pp. 97-8; Pratt, English Coronation Ordines.

46 Nelson, 'The Earliest Surviving Royal Ordo', pp. 343-4; Ordines, ed. Jackson, pp. 73-9. 
that of his son, Charles the Younger, as sub-king of Aquitaine in 855.47 Nelson advanced convincing grounds for thinking that Hincmar had drawn upon the First Ordo to form the Ordo of Judith, as opposed to Schramm's suggestion, that the former had depended on the latter. ${ }^{48}$ It was inherently likely that Hincmar should have drawn on English material for the anointing of a West Saxon queen; the relatively strong evidence for royal consecrations by bishops in Mercia and Northumbria in the late eighth and early ninth century pointed in the same direction. ${ }^{49}$ Such an origin was supported internally by affinities with Insular texts. ${ }^{50}$ Additionally, the view that the First Ordo had enjoyed significant use in England receives support from the prominence, within the Second Ordo, of formulas derived from the First Ordo, which provided a framework for the new English rite. ${ }^{51}$

The scope of that use presents uncertainties. The rarity with which royal anointings are recorded in narrative sources makes any assessment difficult. It is unfortunate that the known anointings of the late eighth and early ninth centuries relate to Mercia and Northumbria, rather than to Wessex. ${ }^{52}$ Only two anointings, that of Ecgfrith in 787 , and the problematic report of Alfred's papal anointing in 853, receive reference in the 'common stock' of the Chronicle. ${ }^{53}$ Yet reports of anointing remain unusual in tenth-century sections of the Chronicle, a period when, on the basis of a number of later sources, it is clear that the anointing of a new king was a routine practice. ${ }^{54}$ As Keynes has commented, 'the inference is not, perhaps, that royal inaugurations [...] were of little importance, but that they happened not to be the kind of detail accorded space in the written record unless of particular

47 Nelson, 'The Earliest Surviving Royal Ordo', p. 351.

48 Ibid., pp. 344-9.

49 Ibid., pp. 351-2.

50 Ibid., pp. 350-1 and 359.

51 That the First Ordo had been used in England before 900 (though not necessarily drafted there) had earlier been accepted by Ward, 'The Coronation Ceremony in Mediaeval England', pp. 162-6; cf. Bouman, Sacring and Crowning, pp. 15 and 156-7.

52 The instances are conveniently assembled by Nelson, 'The Earliest Surviving Royal Ordo', p. 352, n. 56. For Northumbria, see J. Story, Carolingian Connections: Anglo-Saxon England and Carolingian Francia, c. 750 870 (Aldershot, 2003), pp. 156-62; cf. also A. Scharer, Herrschaft und Repräsentation: Studien zur Hofkultur König Alfreds des Großen, Mitteilungen des Instituts für Österreichische Geschichtsforschung 36 (Munich, 2000), 32-8, floating the idea that Æthelbald, king of the Mercians (716-57) had been anointed.

53 Anglo-Saxon Chronicle 785 ABCDEF (= 787) and 853 AB, 854 C (= 853): Two of the Saxon Chronicles Parallel, ed. C. Plummer (Oxford, 1892-9) I, 53-5 and 64 (text); The Anglo-Saxon Chronicle: a Revised Translation, ed. D. Whitelock, with D. C. Douglas and S. I. Tucker (London, 1961), pp. 35 and 43 (translation).

54 For invaluable discussion, see S. Keynes, 'The Burial of King Æthelred the Unready at St Paul's', The English and their Legacy, 900-1200: Essays in honour of Ann Williams, ed. D. Roffe (Woodbridge, 2012), pp. 129-48, pp. 129-48, at 130-7, cf. esp. 132-3, for indications pointing to the general robustness of information relating to royal inaugurations preserved in three sources: the Worcester Latin Chronicle and William of Malmesbury's Gesta regum Anglorum, behind which a common source is suspected; and the works of Ralph de Diceto, active at St Paul's in the late twelfth century, who may have had access to earlier records or testimony. See also idem, 'Church Councils, Royal Assemblies, and Anglo-Saxon Royal Diplomas', Kingship, Legislation and Power in Anglo-Saxon England, ed. G. R. Owen-Crocker and B. W. Schneider (Woodbridge, 2013), pp. 17-182, at 148-50. 
moment'. 55 Perhaps the strongest indication that royal anointing may have been widespread in the ninth century is the original diploma of Ceolwulf I, king of the Mercians, issued on the day of his consecration, 17 September 822, by which the king conveyed land to Wulfred, archbishop of Canterbury, apparently in gratitude for the archbishop's actions. ${ }^{56}$ The diploma gives no hint that the ritual had been unusual, and bears comparison with examples of tenthcentury diplomas seemingly issued by a king on his coronation day. ${ }^{57}$ For Wessex, one must rely on Nelson's valid reasoning, that Æthelwulf is unlikely to have agreed to Judith's anointing if he had not also been anointed. ${ }^{58}$ Some continuity of practice is suggested, firstly, by the consecration of Edward the Elder on Whitsunday ( 8 June) 900, beginning the more or less continuous sequence of known royal inaugurations; and, secondly, by the heavy use of the First Ordo within the Second Ordo. 59

Wulfred's involvement, and the earlier controversy over Ecgfrith's anointing, points to the centrality of Canterbury's role in anointings. ${ }^{60}$ Some form of archiepiscopal prerogative over royal anointings might be set alongside other known activities of archbishops in southern England, such as the presiding over synods of the Southumbrian church, the consecration of southern bishops, and the minting of coinage. ${ }^{61}$ It is clear that Canterbury acted as a place of record-keeping for genealogical and other information relating to the kingdoms of southern England, a practice comparable to the keeping of records relating

55 Keynes, 'The Burial of King Æthelred', pp. 131-2.

56 London, British Library, Cotton Augustus ii. 93: S 186 (CantCC 53); English Historical Documents c. 5001042, ed. D. Whitelock, Eng. Hist. Documents 1, 2nd ed. (London, 1979), 514-16. A facsimile is available on the 'Kemble' website.

57 S 394 (CantStA 26), by which King Æthelstan restored land at Werburginland in Thanet to St Augustine's, 'on the day his consecration', 4 September 925: see S. Keynes, 'King Athelstan's Books', Learning and Literature in Anglo-Saxon England: Studies presented to Peter Clemoes, ed. M. Lapidge and H. Gneuss (Cambridge, 1985), pp. 143-201, at 187-8. S 520 (BCS 815), with English Historical Documents, ed. Whitelock, pp. 551-2 (no. 105), known from its original single-sheet (now lost), by which King Eadred conveyed 7 hides at Warkton, Northamptonshire, to Wulfric pedisequus, in connection with his consecration at Kingston in 946: see Keynes, 'The Burial of King Æthelred', p. 134, n. 34, and below, p. 00/18, n. 123. S 835 (KCD 622), by which King Æthelred conveyed land at Long Sutton, Hampshire, to Æthelwold, bishop of Winchester, for the Old Minster, Winchester, in 979, described as the first estate granted by the king 'post nostram regalem dedicationem': see S. Keynes, The Diplomas of King Athelred 'the Unready' 978-1016: a Study in their Use as Historical Evidence (Cambridge, 1980), p. 238, cf. p. 233, n. 7.

58 Nelson, 'The Earliest Surviving Royal Ordo', p. 353.

59 Æthelweard, Chronicon IV.4 (The Chronicle of Athelweard, ed. A. Campbell (London, 1962), p. 51). The relationship of the First Ordo to the Second Ordo is shown in the Appendix: see below, pp. 00-00/102-5.

60 For the anointing of Ecgfrith, see J. M. Wallace-Hadrill, 'Charlemagne and England', in his Early Medieval History (Oxford, 1975), pp. 154-80, at 157-60; N. Brooks, The Early History of the Church of Canterbury (Leicester, 1984), pp. 117-20; Story, Carolingian Connections, pp. 176-88 and 197-9; S. Keynes, 'The Kingdom of the Mercians in the Eighth Century', Ethelbald and Offa: Two Eighth-Century Kings of Mercia, ed. D. Hill and M. Worthington, BAR Brit. ser. 383 (2005), 1-26, at 14-16.

61 C. Cubitt, Anglo-Saxon Church Councils c.650-c.850 (Leicester, 1995), esp. pp. 17-59 and 65; Brooks, Canterbury, pp. 164-7; Pratt, Political Thought, pp. 56, 145 and 211-12; C. E. Blunt, 'Ecclesiastical Coinage in England. Part I, to the Norman Conquest', NChron 6th ser. 20 (1961), Appendix, pp. i-xvii, at ii-iii and viixii; R. Naismith, 'Money of the Saints: Church and Coinage in Anglo-Saxon England', Studies in Early Medieval Coinage III: Sifting the Evidence, ed. T. Abramson (London, 2014), 68-121, esp. 87-91 and 95-6. 
to episcopal appointment, including the series of formal professions given by southern bishops at the time of their consecration. ${ }^{62}$ Although anointing might seem to imply a special relationship between Canterbury and southern kings, there would be dangers in viewing the ritual as a tool of archiepiscopal power. Ceolwulf's diploma indicates that his consecration attracted attendance comparable to that at a royal assembly, while the location, Bydictun, was probably a royal vill within Mercia. ${ }^{63}$ The political geography of the southern archdiocese required archbishops to juggle relationships with multiple kingdoms, but the implications for anointing are uncertain. ${ }^{64}$ The West Saxon takeover of the south-eastern regions in 825 had important consequences for Canterbury, enshrined in the agreement reached at the council of Kingston in 838 , by which archiepiscopal allegiance was formally transferred to Ecgberht's dynasty. ${ }^{65}$ It is also likely that the holding of synods ceased in the second half of the ninth century. ${ }^{66}$ One might hypothesize that Mercian kings contined to be anointed; alternatively, since Kingston was the location of later anointings, one might envisage a scenario in which, prompted by the agreement, archbishops were restricted to anointing West Saxon kings only. 67

These considerations affect the interpretation of the First Ordo: it is unclear whether the rite should be understood as specifically West Saxon, or as having enjoyed wider use in England. Weight should be accorded, nevertheless, to the connection with Judith, suggesting a rite in use for Wessex by the mid ninth century. ${ }^{68}$ Without precluding the possibility of a rite which had been used more widely, certain features of the First Ordo appear appropriate to the West Saxon political order in the ninth century. ${ }^{69}$ Especially striking is the high degree of dependence on the biblical model of Solomon's anointing. The act of anointing was accompanied by the antiphon 'Zadok the priest' (III Kings I. 45) and Psalm XX, 'The king shall rejoice'. ${ }^{70}$ Solomonic example was also invoked in the acclamation Viuat rex in sempiternum ('May the king live for ever') and in the participation of principes (probably

\footnotetext{
62 S. Keynes, 'Between Bede and the Chronicle: London, BL, Cotton Vespasian B. vi, fols. 104-9', Latin Learning and English Lore: Studies in Anglo-Saxon Literature for Michael Lapidge, ed. K. O'Brian O'Keeffe and A. Orchard, 2 vols. (Toronto, 2005) I, 47-67; idem, 'Episcopal Succession in Anglo-Saxon England', Handbook of British Chronology, 3rd ed., ed. E. B. Fryde, D. E. Greenway, S. Porter and I. Roy, R. Hist. Soc. Guides and Handbooks 2 (London, 1986), 209-24; Canterbury Professions, ed. M. Richter, Canterbury and York Society 67 (Torquay, 1973), esp. xi-xxviii and xxxvi-liv.

63 Pratt, Political Thought, p. 74.

64 Ibid., pp. 44-8, cf. 73-5.

65 Ibid., pp. 18-19 and 45-8; Brooks, Canterbury, pp. 146-7 and 197-201.

66 Pratt, Political Thought, p. 48, with references.

67 Ibid., pp. 74-5.

68 See above, pp. 00-00/8-9.

69 Pratt, Political Thought, pp. 75-8; see also Nelson, 'The First Use of the Second Anglo-Saxon Ordo', pp. 121-2.

70 Pontificale Lanaletense, ed. Doble, p. 60.
} 
referring to ealdormen) in the procedures for enthronement. ${ }^{71}$ As Nelson has observed, the use of Solomon was extreme when compared with Hincmarian ordines, establishing an emphasis which would be continued in the Second Ordo. ${ }^{72}$ The example of Solomon would form an important component of Alfredian ideology, where the language of wealth and wisdom provided a means of describing the responsibilities of those in positions of power. ${ }^{73}$ The Alfredian appeal to Solomon was in part an inventive extrapolation from the existing inauguration ritual. ${ }^{74}$

The treatment of ealdormen (principes) within the First Ordo also aligned with West Saxon political practice. In another distinctive feature, the king was not crowned but received a helmet (galea), probably reflecting the form of royal headgear then in use in England. ${ }^{75}$ As Nelson has argued, the central item of regalia was the short sceptre (sceptrum), 'signifying law as equity' and forming the first investiture, followed by the staff (baculus) and helmet (galea). ${ }^{76}$ Whereas 'all the bishops' participated in the act of anointing, 'all the bishops with the ealdormen' collectively gave the sceptre. ${ }^{77}$ Nelson has emphasized the uniqueness of the First Ordo in this respect, as 'the only extant Ordo to prescribe the active participation of laymen within the liturgical rite proper - in striking contrast with the West Frankish Ordines tradition from Hincmar onwards'. ${ }^{78}$ The practice harmonizes with the tendency for the offices of ealdorman and bishop to be equated in West Saxon political culture, a view which may have reflected the role of bishops in royal service. ${ }^{79}$ A parallel may also be suggested between the Kingston agreement and the 'three precepts', statements of rulership issued after the enthronement which the king was to enjoin upon his subject people. 80 According to the first precept, 'the church of God and the whole Christian people' were to 'preserve true peace at all times'; those assembled at Kingston had sought to preserve 'the peace and unanimity of the churches of God and of the whole Christian people subject to their secular authority through the grace of almighty God, by the bond of very firm love'. ${ }^{81}$ The similarity of the

71 Ibid., p. 62, with Nelson, 'The Earliest Surviving Royal Ordo', pp. 358-9, cf. p. 356; III Kings I. 39 and I Chronicles XXIX. 22-4.

72 Nelson, 'The Earliest Surviving Royal Ordo', p. 355.

73 Pratt, Political Thought, pp. 151-66, 170-6, 191-2, 280-95, 304-7, 317-21, 328-9, 334-42, 344-5, 349-50.

74 Ibid., pp. 157, 165, 229, 232 and 339, cf. 75-6.

75 Pontificale Lanaletense, ed. Doble, p. 62; Nelson, 'The Earliest Surviving Royal Ordo', pp. 356-8.

76 Pontificale Lanaletense, ed. Doble, pp. 60-2; Nelson, 'The Earliest Surviving Royal Ordo', p. 356.

77 Pontificale Lanaletense, ed. Doble, p. 60.

78 Nelson, 'The Earliest Royal Ordo', p. 356.

79 Pratt, Political Thought, pp. 69-70 and 219, cf. pp. 52-8 and 77.

80 Pontificale Lanaletense, ed. Doble, p. 63, with Nelson, 'The Earliest Surviving Royal Ordo', p. 358. S 1438 (CantCC 69). Facsimiles are available on the 'Kemble' website.

81 'In primis ut ecclesia dei et omnis populus christianus ueram pacem seruent in omni tempore': Pontificale Lanaletense, ed. Doble, p. 63, with Nelson, 'The Earliest Surviving Royal Ordo', p. 358. 'Pax et unianimitas ecclesiarum Dei totiusque populi Christiani eorum seculari dicioni per Dei omnipotentis gratiam subiecti firmissimi dilectionis uinculo': S 1438 (CantCC 69). Pratt, Political Thought, p. 76; also Scharer, Herrschaft und Repräsentation, pp. 26-7. 
language is striking since, as Nelson observed, the opening of the three precepts section, Rectitudo regis est, recalls formulation in Insular texts such as De duodecim abusivis saeculi. 82

It seems significant that the First Ordo lacks a queen's ordo. As Stafford and Nelson have implied, the case for a West Saxon context for the First Ordo appears strengthened by the West Saxon custom - reported by Asser in the context of Æthelwulf's marriage to Judith, and regarded by him as unusual and wrongful - by which a queen was not permitted to sit beside the king on the royal throne, nor to bear the title 'queen' but rather 'king's wife'. ${ }^{83}$ The existence of such a custom receives support from the direct reference to it in the Annals of StBertin, and from the shadowy profiles of Æthelwulf's first wife, Osburh, and of Alfred's wife, Ealhswith. ${ }^{84}$ A low status for consorts may have had advantages for a dynasty tightening its grip on the kingdom, in circumstances which made use of fraternal succession. ${ }^{85}$ Asser traced the practice back to the malign influence of Eadgifu, Offa's daughter, who married King Beorhtric in the late eighth century, but interpretation is complicated by the narrative context, and by possible indications in the charter record that the title of queen had been claimed for Judith and for Wulfthryth, consort of Alfred's elder brother, Æthelred. ${ }^{86}$ As Stafford has argued, it may be helpful to regard the story of Eadburh as a flexible tool used to justify the downgrading of the status of royal wives, which suited some parties more than others. ${ }^{87}$ The story may have been deployed by those opposed to Æthelwulf's return in 856, and may in Alfred's time have served to attribute the low status of Ealhswith to her Mercian origins. ${ }^{88}$ If, as it seems, West Saxon consorts had not normally been anointed in the ninth century, whatever arrangements may have prevailed in Mercia are

82 Nelson, 'The Earliest Surviving Royal Ordo', p. 359.

83 Asser, Vita Alfredi, c. 13 (Asser's Life of King Alfred, together with the Annals of St Neots, erroneously ascribed to Asser, ed. W. H. Stevenson, new imp. (Oxford, 1959), p. 11, lines 8-15; S. Keynes and M. Lapidge, Alfred the Great: Asser's Life of King Alfred and Other Contemporary Sources (Harmondsworth, 1983), p. 71). P. Stafford, 'The King's Wife in Wessex 800-1066', 'Charles the Bald, Judith and England', and 'Succession and Inheritance: a Gendered Perspective on Alfred's Family History', all in her Gender, Family and the Legitimation of Power (Aldershot, 2006), no. IX, pp. 3-27, at 16-17, no. I, pp. 139-53, at 1434 and 147-9, and no. III, pp. 251-64, at 257 and 263-4. Nelson, 'The Earliest Surviving Royal Ordo', p. 351.

84 Annals of St-Bertin s.a. 856 (Les Annales de Saint Bertin, ed. F. Grat, J. Vielliard and S. Clémencet (Paris, 1964), p. 73; J. L. Nelson, The Annals of St-Bertin (Manchester, 1991), p. 83); Keynes and Lapige, Alfred, pp. 235-6, n. 28. For Osburh and Ealhswith, see J. L. Nelson, 'Reconstructing a Royal Family: Reflections on Alfred, from Asser, Chapter Two', in her Rulers and Ruling Families, no. III, pp. 47-66, at 54-6 and 65.

85 Stafford, 'The King's Wife in Wessex', pp. 10-12 and 16-17.

86 Vita Alfredi, cc. 13-15 (ed. Stevenson, p. 11, line 15, to p. 14, line 26; Keynes and Lapidge, Alfred, pp. 71-2). Nelson, 'Reconstructing a Royal Family', p. 55; Stafford, 'Succession and Inheritance', pp. 255 and 259.

87 Stafford, 'Succession and Inheritance', pp. 261-4, implicitly responding to Nelson's earlier observations ('Reconstructing a Royal Family', pp. 55-6).

88 Stafford, 'Succession and Inheritance', pp. 263-4. See also J. L. Nelson, 'The Queen in Ninth-Century Wessex', Anglo-Saxons: Studies presented to Cyril Roy Hart, ed. S. Keynes and A. P. Smyth (Dublin, 2006), pp. 69-77, at 69-73; B. Yorke, 'Edward as Ætheling', Edward the Elder 899-924, ed. N. J. Higham and D. H. Hill (London, 2001), pp. 25-39, at p. 31. 
hidden from view. ${ }^{89}$ A direct connection between West Saxon practices and the First Ordo is suggested by Hincmar's drafting of the Ordo for Judith, which provides independent evidence that Judith's status had been regarded as anomalous. 90 A connection is also suggested by Asser's emphasis on the significance of the royal throne: the procedures for enthronement in the First Ordo, involving many elements of the political community, might provide a context for the practice reported by Asser, of the restricting of the throne to kings. ${ }^{91}$

The First Ordo differs from the Hincmarian ordines in representing kingship as an office with responsibilities towards the people in general, unmediated by any special relationship between the king and bishops. ${ }^{92}$ Whereas the political role of the Frankish church, and the agenda of ecclesiastical reform, generated a form of ritual in which special royal responsibilities were expressed towards the ecclesiastical order, the First Ordo appealed to qualities exhibited by the king to his people in general, reflecting the different character of the Southumbrian church. ${ }^{93}$ Central was the king's role in judgement, which in Hincmarian ordines found expression in procedures preliminary to the anointing, by means of a formal announcement or promise by the ruler, issued to bishops as guarantors of the king's goodwill. ${ }^{94}$ The only comparable element in the First Ordo, the three precepts, took the form of a declaration issued after the anointing and enthronement. ${ }^{95}$ Whereas the West Frankish preliminaries typically concerned the king's responsibilities towards the church and the laws of his predecessors, the three precepts identified expectations incumbent on the king's subject people. ${ }^{96}$ In addition to the first precept, requiring the preservation of peace by 'the church of God and the whole Christian people', the king also forbade 'thefts and all injustices among all orders', and by the third precept he enjoined 'equity and mercy in all judgements, that through this the clement and merciful God may grant us his mercy'. 97 While in general these

89 Nelson, 'The Earliest Surviving Royal Ordo', p. 351, n. 51; cf. Stafford, 'Charles the Bald, Judith and England', pp. 147-9; idem, 'Succession and Inheritance', p. 259. The story of Eadburh would acquire added charge if she had herself been anointed on her marriage to Beorhtric in 789 (two years after Ecgfrith's anointing). The point is speculative, however, and her condemnation can be sufficiently explained by other means.

90 Nelson, 'The Earliest Surviving Royal Ordo', p. 351.

91 Pontificale Lanaletense, ed. Doble, p. 62; Nelson, 'The Earliest Surviving Royal Ordo', pp. 356 and 358-9. Cf. Vita Alfredi, c. 13 (ed. Stevenson, p. 11, lines 8-12; Keynes and Lapidge, Alfred, p. 71).

92 Nelson, 'The Earliest Surviving Royal Ordo', p. 351; Pratt, Political Thought, pp. 76-7.

93 Pratt, Political Thought, pp. 60, 72-3 and 76-7, cf. 44-58.

94 Nelson, 'Kingship, Law and Liturgy', pp. 149-55; Bouman, Sacring and Crowning, pp. 141-2.

95 Pontificale Lanaletense, ed. Doble, p. 63; Nelson, 'The Earliest Surviving Royal Ordo', pp. 358-9; Bouman, Sacring and Crowning, pp. 142-3.

96 For the West Frankish sequence, see Ordines, ed. Jackson, pp. 101 (Responsio of Charles the Bald in 869), 118 and 120 (promissio of Louis the Stammerer in 877), 138 (promissio of Odo in 888) and 147 (Erdmann Ordo), cf. p. 132 (promissio of Carloman in 882).

97 'In primis ut ecclesia dei et omnis populus christianis ueram pacem seruent in omni tempore. Aliud est ut rapacitates et omnes iniquitates omnibus gradibus interdicat. Tertium est ut in omnibus iudiciis equitatem et misericordiam precipiat. ut [per hoc] nobis indulgeat suam misericordiam clemens et misericors deus': Pontificale Lanaletense, ed. Doble, p. 63, with Nelson, 'The Earliest Surviving Royal Ordo', p. 358 
expectations might harmonize with certain aspects of Anglo-Saxon dispute-settlement as suggested by the early law-codes, at a deeper level their generalized nature probably reflects the relative institutional weakness of the church and its landholding in pre-viking England. ${ }^{98}$

In further agreement with Insular texts such as De duodecim abusivis saeculi, the king was represented by the First Ordo as standing in direct relationship to God, typically as 'servant' (famulus), bearing responsibility for the welfare of his people. ${ }^{99}$ His central qualities comprised a range of virtues, especially justice, equity, mercy and wisdom, displayed towards his people and inculcated with divine support. The king's efforts were encouraged by the hope of divine favour, with reference to the prior support shown to Old Testament kings and the people of Israel. One of the initial blessings, In diebus, connected the king's just and peaceful rule with the attainment of wealth, bodily health and wider prosperity. ${ }^{100}$ The blessings that followed the investiture of the sceptre listed the rewards of faithful service, from a peaceful kingdom to victorious military defence against external enemies. ${ }^{101}$ After the investitures of the staff and the helmet, two further blessings, Omnipotens det tibi deus and Benedic domine fortitudinem, evoked the time of the patriarchs, soliciting natural fruitfulness and 'an abundance of corn and wine'. ${ }^{102}$ The responsibility of securing the benefits of just rule lay directly with the king.

\section{The principal versions of the Second Ordo}

In use in the ninth century, the First Ordo was then subject to a major updating to form the Second Ordo. One should distinguish between two versions of the Second Ordo: firstly, the earlier A-version, represented by the Sacramentary of Ratold and by a large group of Continental manuscripts; and, secondly, the later B-version, transmitted in a number of later Anglo-Saxon pontificals. ${ }^{103}$ The A-version incorporated, as part of the preliminaries to anointing, a royal promise to preserve 'canonical privilege and due law and justice'; the Bversion mainly differed in the recasting of the preliminary section, in which the promise of the A-version was replaced with a new three-fold promise modelled on the three precepts. ${ }^{104}$ The overall effect was to remove the declaratory character of the three precepts, and instead to incorporate acceptance of them within the king's promise. ${ }^{105}$ As Stafford has shown, the

\footnotetext{
98 Pratt, Political Thought, pp. 76-7, cf. pp. 20, 24-6 and 44-58.

99 Ibid., p. 77.

100 Pontificale Lanaletense, ed. Doble, p. 60.

101 Ibid., p. 61.

102 Ibid., p. 62.

103 Nelson, 'The Second English Ordo', pp. 361-5. For the A-version, see P. L. Ward, 'An Early Version of the Anglo-Saxon Coronation Ceremony’, EHR 57 (1942), 345-61; Ordines, ed. Jackson, pp. 168-200. The Bversion is cited below from Claudius Pontificals, ed. Turner, pp. 89-97.

104 Nelson, 'The Second English Ordo', pp. 362-3.

105 Nelson, 'The Second English Ordo', pp. 369-70. Sacramentary of Ratoldus, ed. Orchard, pp. 47-8. Cf. Claudius Pontificals, ed. Turner, pp. 89-90.
} 
B-version can be linked with significant developments in later Anglo-Saxon political ideas and practice, relating to commitments issued by a king in connection with his consecration: the strongest evidence concerns Æthelred II's return to England in 1014 and Cnut's lawgiving. ${ }^{106}$ The B-version therefore amounted to an important revision of the Second Ordo, probably undertaken in the mid tenth century, and disseminated widely in late Anglo-Saxon pontificals. ${ }^{107}$ The B-version also found vernacular expression in the Promissio regis, a tract on the responsibilities of kingship which incorporated in its opening section an Old English translation of the three-fold promise of the B-version, described as replicating 'the document which Archbishop Dunstan gave our lord at Kingston on the day when he was consecrated as king'. ${ }^{108}$ Mary Clayton has advanced plausible grounds for associating the tract with Wulfstan, archbishop of York, though there are some inconsistencies of vocabulary and style, and it may possibly represent a reworking of pre-existing material. ${ }^{109}$ If the tract had indeed been drafted by Wulfstan, and for a king anointed by Dunstan, then this might imply that the king had been Æthelred II, but there are various uncertainties of interpretation. ${ }^{110}$ The treatment of the vernacular promise renders credible the supposition that later Anglo-Saxon kings had been accustomed to make their promise in English. ${ }^{111}$

The earliest witness of the A-version is the Sacramentary of Ratold (Paris, Bibliothèque nationale de France, lat. 12052), a combined sacramentary, pontifical and

106 P. Stafford, 'The Laws of Cnut and the History of Anglo-Saxon Royal Promises', ASE 10 (1982), 173-90, at 179 and 182-90. See also J. Campbell, 'The Late Anglo-Saxon State: a Maximum View', in his The AngloSaxon State (London, 2000), pp. 1-30, at 22-3; S. Keynes, 'Edward the Ætheling (c. 1005-16)', Edward the Confessor: the Man and the Legend, ed. R. Mortimer (Woodbridge, 2009), pp. 41-62, at 51-3; J. R. Maddicott, The Origins of the English Parliament, 924-1327 (Oxford, 2010), pp. 34-41. G. Molyneaux, The Formation of the English Kingdom in the Tenth Century (Oxford, 2015), pp. 218-22, cf. p. 188.

107 Nelson, 'The Second English Ordo', 369-74; Turner, Claudius Pontificals, pp. xxxi-xxxiii; P. Wormald, The Making of English Law: King Alfred to the Twelfth Century. I: Legislation and its Limits (Oxford, 1999), 4478; Molyneaux, Formation of the English Kingdom, p. 188. The contextualization of the B-version, and the variant of it transmitted in the Benedictional of Archbishop Robert, is a complex question with textual and historical dimensions: I hope to consider it elsewhere.

108 M. Clayton, 'The Old English Promissio regis', ASE 37 (2008), 91-150, at 148-9. Although largely modelled on the promise of the B-version, the translation also reflected certain readings known from the three precepts of the First Ordo (ibid., pp. 110-12). See also Maddicott, Origins of the English Parliament, pp. 346. The Promissio regis appears to be unrelated to the text preserved in the fifteenth-century cartulary of Athelney abbey, purporting to be the coronation oath of King Alfred: ptd in English from George Harbin's transcript in Two Cartularies of the Benedictine Abbeys of Muchelney and Athelney in the County of Somerset, ed. E. H. Bates, Somerset Record Soc. 14 (London, 1899), 126. For the cartulary, which came to light at Petworth House in 2001, see the file on Athelney by Simon Keynes on the 'Kemble' website, with references. As Ward noted ('The Coronation Ceremony in Mediaeval England', p. 166, n. 3), the Athelney text corresponds to the form of royal promise in the Third Recension.

109 Clayton, 'The Old English Promissio regis', esp. pp. 131-45.

110 Ibid., p. 145-7, cf. 92-5 and 130-1.

111 As Clayton points out, it is possible that the promise had been taken in Latin, following the B-version ('The Old English Promissio regis', pp. 112-13); nevertheless, the tract's early reference to a 'writ' or 'document' (gewrit), administered by Dunstan and seemingly laid on 'Christ's altar', warrants respect. The laying of a king's written promise on the altar as part of the preliminaries has a West Frankish parallel: Ordines, ed. Jackson, p. 132 (promissio of Carloman in 882, referring to his anointing in 879). 
benedictional, written in northern Francia in the late tenth century. ${ }^{112}$ The core of the pontifical and benedictional comprises material derived from an earlier English pontifical, probably of Canterbury origin and of mid or later tenth-century date: the royal ordo occurs within the pontifical. ${ }^{113}$ The Ratold text preserves the Second Ordo in an early form, and has generally been regarded as the key witness to the A-version. ${ }^{114}$ Nevertheless, as Nelson has shown, using the evidence of the anointing prayer, Omnipotens sempiterne deus, it is clear that the A-version circulated in at least two distinct forms. 115 The matter is complicated by the transmission of an English text within Continental manuscripts, which led to the prayer being partially adapted for Frankish circumstances. ${ }^{116}$ Thus the Ratold text had the readings regnum [...] albionis totius uidelicet francorum pariter ('the kingdom of all Albion namely equally of the Franks') and totius albionis ecclesiam ('the church of all Albion'), implying kingship of all Britain, but also regale solium uidelicet francorum sceptra ('the royal throne namely the sceptres of the Franks'). The remaining Continental manuscripts have the unspecific readings regnum pariter ('the kingdom equally') and totius regni ecclesiam ('the church of the whole kingdom'), but also regale solium uidelicet saxonum merciorum nordanhimbrorumque sceptra ('the royal throne namely the sceptres of the Saxons, Mercians and Northumbrians'), a feature which has prompted the convenient label 'SMN'.117 The nomenclature clearly relates to the enhanced status of the West Saxon dynasty in the tenth century, arising from the formation of a single kingdom of the English, and from aspirations to the rulership of all Britain. The nature of the text underlying these witnesses is, however, difficult to determine precisely.

112 Orchard, Sacramentary of Ratoldus, pp. xiii-cxciii. From an entry added to the calendar, the volume appears to have been produced for Ratoldus, abbot of Corbie (c. 972-86); production has conventionally been ascribed to St-Vaast, Arras, on the basis of the calendar, but, as Orchard has argued, the book's localization is complicated by the variegated nature of its overall contents (ibid., pp. xiii-xiv, xxx-xxxi and cxii-cxciii); see also C. E. Hohler, 'Some Service-Books of the Later Anglo-Saxon Church', Tenth-Century Studies, ed. D. Parsons (Chichester, 1975), pp. 60-83 and 217-27, at 64-7 and 69.

113 The pontifical includes an episcopal profession close to the form known to have been used by Archbishop Wulfred for Herewine, bishop-elect of Lichfield, 814 x 816 (15v-16r): Sacramentary of Ratoldus, ed. Orchard, p. 39. Richter, Canterbury Professions, pp. xlvii-li and p. 9; Brooks, Canterbury, pp. 164-5; cf. Hohler, 'Some Service-Books', pp. 64-7 and 69. See esp. A. Prescott, 'The Text of the Benedictional of St Æthelwold', Bishop Athelwold: his Career and Influence, ed. B. Yorke (Woodbridge, 1988), pp. 119-47, at 135-42, and Orchard, Sacramentary of Ratoldus, esp. p. xxxi-xxxiii, for considerations, including the probable use of the Romano-Germanic Pontifical, which would suggest that the putative English pontifical had been produced within the period c. $960-$ c. 980.

114 Cited here from Sacramentary of Ratoldus, ed. Orchard, pp. 47-55. The forthcoming edition in Pratt, English Coronation Ordines, aligns the Ratold text with the texts of the probable sources of the A-version, as laid out in the Appendix: see below, pp. 00-00/102-5.

115 Nelson, 'The Second English Ordo', pp. 363-5; see also Hohler, 'Some Service Books', pp. 67-8.

116 The relevant readings are laid out in the Appendix: see below, pp. 00-00/83-5.

117 Ward, 'The Coronation Ceremony in Medieval England', pp. 168-70; idem, 'An Early Version of the AngloSaxon Coronation Ceremony'; Nelson, 'The Second English Ordo', p. 363. 
Two possible reconstructions are laid out in the Appendix.118 Overall, 'SMN' manuscripts preserve readings which are closer than Ratold to the rite's probable sources, suggesting an earlier phase of textual development. ${ }^{119}$ One might envisage that the 'SMN' and Ratold texts preserve separate versions of the Second Ordo. ${ }^{120}$ The overall scope of rule in the 'SMN' text might suggest the reign of Æthelstan (924-39), after his takeover of Northumbria in 927, yet allowances should be made for the parallel with the title favoured in the later 'alliterative' charters, 'king of the Anglo-Saxons, Northumbrians, pagans and Britons'. ${ }^{121}$ Rule over 'Albion', while again associated with Æthelstan, recurs prominently under Eadred (946-55) in the 'Dunstan B' charters, first found in the early 950s. ${ }^{122}$ On this reconstruction, the 'SMN' text could have been drafted under Edmund or Eadred, whereas the Ratold text could derive from a version produced in the latter part of Eadred's reign. ${ }^{123}$ Nevertheless, it should be noted that the points in the prayer where 'Albion' readings are present in the Ratold text ('regnum [...] albionis totius' and 'totius albionis ecclesiam') are distinct from the operative reading in the 'SMN' text, 'regale solium uidelicet saxonum merciorum nordanhimbrorumque sceptra'. It is possible, therefore, that both the Ratold and 'SMN' texts ultimately descend from a common English archtype, in which the references to Albion and to Saxons, Mercians and Northumbrians were combined. ${ }^{124}$ This would imply production in the $940 \mathrm{~s}$ or $950 \mathrm{~s}$, by comparison with the 'alliterative' charters, and might point

\footnotetext{
118 See below, pp. 00-00/83-92.

119 See Pratt, English Coronation Ordines.

120 See below, pp. 00-00/87-9.

121 Keynes, 'England, c. 900-1016', pp. 469-70 and 473-4. For the 'alliterative' charters, see C. Hart, 'Danelaw and Mercian Charters of the Mid Tenth Century', in his The Danelaw (London, 1992), 431-55; S. Keynes, 'Koenwald', The Wiley Blackwell Encyclopaedia of Anglo-Saxon England, ed. M. Lapidge, J. Blair, S. Keynes and D. Scragg, 2nd ed. (Oxford, 2014), pp. 279-80, with references; idem, 'Church Councils, Royal Assemblies', pp. 57 and 92-5. See also idem, 'The Henry Loyn Memorial Lecture for 2008: Welsh Kings at Anglo-Saxon Royal Assemblies (928-55)', HSJ 26 (2014), 69-122, at 96-104, 106-7 and 119-21. As Keynes points out (p. 96, n. 111), the 'SMN' styling would have an Alfredian precedent in the title 'rex S(axonum) (et) M(erciorum)', known from specimens of Alfred's Cross-and-Lozenge coinage from the mid 870s: see idem, 'King Alfred and the Mercians', pp. 14 and 18; R. Naismith, 'Evidence of an Anglo-Saxon Alliance', Hist. Today 66:3 (March 2016), 4-5, at 5. The analogy supports the connection here posited with the styling of the 'alliterative' charters.

122 H. Loyn, 'Wales and England in the Tenth Century: the Context of the Athelstan Charters', in his Society and Peoples: Studies in the History of England and Wales, c. 600-1200 (London, 1992), pp. 173-99; Keynes, 'Welsh Kings at Anglo-Saxon Royal Assemblies', p. 103, n. 139. S. Keynes, 'The "Dunstan B" Charters', ASE 23 (1994), 165-93, at 180 and 183; idem, 'Church Councils, Royal Assemblies', pp. 57 and 95-7.

123 A similar path of development is suggested by Molyneaux, Formation of the English Kingdom, p. 188, n. 333. Cf. S 520 (BCS 815), with English Historical Documents, ed. Whitelock, pp. 551-2 (no. 105), the issuing of which is associated with Eadred's consecration at Kingston in 946: see Keynes, 'Welsh Kings at AngloSaxon Royal Assemblies', pp. 98 and 119-20. The testimony of this remarkable diploma is equivocal on the scope of rule envisaged: Eadred is styled 'king of the Anglo-Saxons, Northumbrians, pagans and Britons', while the witness-list includes the attestions of three Welsh sub-kings.

124 As implied by J. A. Robinson, 'The Coronation Order in the Tenth Century', JTS 19 (1917), 56-72, at 71; cf. Ward, 'The Coronation Ceremony in Mediaeval England', p. 169. See below, pp. 00-00/90-2.
} 
specifically to the reign of Eadred (946-55) on the basis of the 'Dunstan B' charters. ${ }^{125}$ Although this reconstruction assumes an additional layer in the textual transmission, it would have the attraction of bringing the Ordo closer to the charter record where, at least in general in the tenth century, the notion of ruling Britain or Albion more usually complements, rather than replaces, the claim to kingship over the English. ${ }^{126}$ The effect of either reconstruction is to imply a post-939 dating for the subsequent phase or phases of A-version text, which would allow such development to sit suggestively within the tenure of Oda as archbishop of Canterbury (941-58). ${ }^{127}$

The other form in which the A-version of Second Ordo circulated is not wholly preserved, but, as Nelson showed, strongly implied by certain features of the Ratold and 'SMN' texts. ${ }^{128}$ The presence of pariter ('equally') in both texts, serving no grammatical purpose in the 'SMN' text, together with the shared reference to 'both these peoples' (utrorumque horum populorum), indicates that the original nomenclature had been neither Albion nor Saxons, Mercians and Northumbrians, but a combination of two peoples. As Nelson has argued, that original combination appears to have been preserved in the Bversion, in the readings regnum anglorum uel saxonum pariter ('the kingdom of the Angles or Saxons equally'), totius regni anglosaxonum ecclesiam ('the church of the whole kingdom of the Anglo-Saxons') and regale solium uidelicet anglorum uel saxonum sceptra ('the royal throne namely the sceptres of the Angles or Saxons'); while the clause expressing the hope that the king 'might deserve by your mercy through a lengthy span of life to establish and govern the apex of paternal glory unitedly', a departure from the anointing prayer's probable source, might seem appropriate to the uniting of two peoples. ${ }^{129}$ Nelson's finding has added significance in the light of important work by Keynes on relations between Wessex and Mercia in the ninth and early tenth centuries, in which the same notion of the "AngloSaxons', the Angli Saxones or Angli et Saxones, was the decisive form of identity. ${ }^{130} \mathrm{King}$ Alfred's newly adopted title in diplomas from the 880s onwards, 'king of the Anglo-Saxons',

\footnotetext{
125 The latter part of Eadred's reign would present circumstances in which the production of diplomas encompassed both 'alliterative' and 'Dunstan B' forms. See esp. S 569 (Bur 13), dated 955, an 'alliterative' charter in which Eadred is also styled 'rex tocius Britanniae'. For the context of the claims made on Eadred's behalf, see Keynes, 'Welsh Kings at Anglo-Saxon Royal Assemblies', pp. 98-104, 106-7 and 119-20. For Eadred's consecration, see above, p. 00/10, n. 57, and p. 00/18, n. 123.

126 Keynes, 'England, c. 900-1016', p. 470; idem, 'Welsh Kings at Anglo-Saxon Royal Assemblies'; pp. 86-7, 89, 93 and 119-20. S. Keynes, 'Edgar, Rex Admirabilis', Edgar, King of the English, 959-975: New Interpretations, ed. D. Scragg (Woodbridge, 2008), pp. 3-80, at p. 25. See also J. Crick, 'Edgar, Albion and Insular Dominion', Edgar, ed. Scragg, pp. 158-70.

127 Brooks, Canterbury, pp. 222-37; M. Lapidge, 'Oda', The Wiley Blackwell Encyclopaedia, ed. Lapidge et al., pp. 346-7. Cf. John of Worcester, Chronicon, s.a. 946 and 955, in The Chronicle of John of Worcester II, ed. R. R. Darlington and P. McGurk, with J. Bray (Oxford, 1995), 398-400 and 404, for the identification of Oda as having officiated at the coronations of Eadred and Eadwig.

128 Nelson, 'The Second English Ordo', pp. 364-5; see also Hohler, 'Some Service Books', p. 68.

129 Nelson, 'The Second English Ordo', p. 365.

130 Keynes, 'King Alfred and the Mercians'; idem, 'Edward, King of the Anglo-Saxons'.
} 
reflected the extension of his rule to western Mercia, c. 880, and described a new form of political unity, in which the 'Saxon' West Saxon kingdom, and its south-eastern regions, had been combined with 'Anglian' Mercia. ${ }^{131}$ The 'kingdom of the Anglo-Saxons' continued under Edward the Elder, and the title found use in diplomas early in Æthelstan's reign, before the takeover of Northumbria in 927 prompted the fuller title 'rex Anglorum'. 132 The scope of rule over the 'Anglo-Saxons' indicates 880 x 925 as outer limits for the compilation of the Second Ordo.

The idea that the Second Ordo replaced the First Ordo directly has generally been assumed, but needs defending given the existence of a variant version of the First Ordo. Two eleventh-century pontificals of Milanese origin, Milan, Biblioteca del Capitolo Metropolitano, II-D-03-007 (formerly n. 21 or H. 9 or D 1-11) and Vatican City, Biblioteca Apostolica Vaticana, lat. 13151, preserve a hybrid version of the First Ordo, in which the main elements are combined with the Ordo of Seven Forms, the West Frankish ordo which has often been regarded as a source for the Second Ordo. ${ }^{133}$ The hybrid text was identified by Schramm as a 'Lombard Ordo' of the eleventh century, while Reinhard Elze has suggested a context in the crowning of north Italian rulers in the tenth century. ${ }^{134}$ Anton Scharer has proposed an English origin for the Milan text, however, suggesting that it might represent an intermediate stage between the First and Second Ordines. ${ }^{135}$ The idea is an interesting one, but several considerations point against this possibility. Firstly, the Milan text incorporates much from the Ordo of Seven Forms which is not present in the Second Ordo. The Milan text borrows the two anointing prayers, the tradition formulas for the crown, sceptre (uirga), sword and ring, and a set of formulas for the anointing of a queen. ${ }^{136}$ Of these, only the two anointing prayers and the uirga formula are represented in the Second Ordo; the Milan text also has only a shortened version of the enthronement prayer, Sta et retine, which appears in full in the Second Ordo. ${ }^{137}$ Secondly, as will be discussed below, there are strong grounds for

131 Keynes, 'King Alfred and the Mercians', pp. 25-9 and 34-45; R. Abels, Afred the Great: War, Kingship and Culture in Anglo-Saxon England (Harlow, 1998), pp. 169-86; Pratt, Political Thought, pp. 93-107 and 16678.

132 Keynes, 'Edward, King of the Anglo-Saxons', pp. 48-51; idem, 'England, c. 900-1016', pp. 468-9.

133 Bouman, Sacring and Crowning, pp. 23-4 and 135; Pontificale in usum ecclesiae Mediolanensis necnon Ordines Ambrosiani ex codicibus saec. IX-XV, ed. M. Magistretti, Monumenta Veteris Liturgiae Ambrosianae 1 (Milan, 1897), pp. 112-20, cf. xxvii-xxxiii; Ordines, ed. Jackson, pp. 155, 157 and 159-67 (MS B).

134 Schramm, Kaiser, Könige und Papste II, 225; R. Elze, 'Ordines für die Königskrönung in Mailand', Cristianità ed Europa. Miscellanea di studi in onore di Luigi Prosdocimi, ed. C. Alzati, 2 vols. (Rome, 19942000) I.1, 175-89, at 176-8.

135 Scharer, Herrschaft und Repräsentation, pp. 42-8; A. Scharer, 'Objects of Royal Representation in England and on the Continent', Anglo-Saxon Traces, ed. J. Roberts and L. Webster (Tempe, AZ, 2011), pp. 31-45, at p. 43.

136 Pontificale in usum ecclesiae Mediolanensis, ed. Magistretti, pp. 112-3, 114, 115-17 and 120 (the queen's ordo is complete in the Vatican lat. 13151). Cf. Ordo of Seven Forms 1-7 and 9-13 (Ordines, ed. Jackson, pp. 159-63 and 164-7).

137 Sacramentary of Ratoldus, ed. Orchard, pp. 49-50, 51 and 54. Cf. Pontificale in usum ecclesiae Mediolanensis, ed. Magistretti, p. 117. 
thinking that the compiler of the Second Ordo had access to a shorter version of the Ordo of Seven Forms, here termed the Leiden Ordo, rather than the full Ordo of Seven Forms, as used in the Milan text. 138 Thirdly, the First Ordo is known to have enjoyed some circulation on the Continent, so its use in the Milan text need not be diagnostic. Finally, the Milan text has parallels with the full German Ordo, as represented in the Romano-Germanic Pontifical, since in both cases many formulas borrowed from the Ordo of Seven Forms, were used to supplement an existing ordo. ${ }^{139}$ Collectively, these considerations place the Milan text at some distance from the Second Ordo; it may perhaps have represented a Continental compilation informed or inspired by the full German Ordo. ${ }^{140}$

\section{The sources of the Second Ordo}

It is instructive to consider the main changes represented by the Second Ordo. The new rite appears to have been a major work of compilation taking the First Ordo as a starting point, which was then revised to include material from a number of West Frankish ordines. ${ }^{141}$ The First Ordo was included in its entirety, with the exception of the tradition formulas, reflecting a substantial alteration and expansion in the regalia. The helmet was replaced with a crown, and rather than a sceptre and staff (baculus), the king was now invested with a ring, sword, sceptre and rod (uirga), each with its own tradition formula and blessing. ${ }^{142}$ The West Frankish origin of the new tradition formulas indicates that the Second Ordo involved a major revision of the regalia in line with Continental precedent. ${ }^{143}$ Yet there were further

\footnotetext{
138 See below, pp. 00-00/28-35.

139 Bouman, Sacring and Crowning, pp. 30-7, 86, 132, 135, 159-60; C. Erdmann, Forschungen zur politischen Ideenwelt des Frühmittelalters, ed. F. Baethgen (Berlin, 1951), pp. 56-9; Le pontifical romano-germanique du dixième siècle, ed. C. Vogel and R. Elze, 3 vols., Studi e testi 226-7 and 269 (Vatican City, 1963-72) I, 24661. The Romano-Germanic Pontifical (hereafter $P R G$ ) has conventionally been regarded as a standardizing form of pontifical, probably originating in Mainz c. 960, which exerted extensive influence from the later tenth century onwards. This view has been subject to important questioning by Henry Parkes, who has highlighted certain composite features of Vogel and Elze's text, and manuscript evidence suggesting a lack of concord between the $P R G$ and liturgical material available at Mainz in the tenth century: H. Parkes, 'Questioning the Authority of Vogel and Elze's Pontifical romano-germanique', Understanding Medieval Liturgy: Essays in Interpretation, ed. H. Gittos and S. Hamilton (Farnham, 2016), pp. 75-101; idem, The Making of Liturgy. Aspects of Parkes's case might be debated, including the treatment of Ordo Romanus 50, credibly regarded as having been compiled in the mid tenth century and strongly associated with the PRG (cf. The Making of Liturgy, pp. 93-100). Parkes himself acknowledges the existence of 'a very significant textual tradition' which 'rose to prominence in late tenth- or early eleventh-century Germany' and 'metamorphosed wildly in its remarkable transmission across Europe in a manner which is not yet understood' ('Questioning the Authority', p. 100).

140 Cf. Bouman, Sacring and Crowning, pp. 23-4.

141 The relationship of the A-version to its probable sources is laid out in the Appendix: see below, pp. 00$00 / 102-5$.

142 For the new regalia, cf. Nelson, 'The First Use of the Second Anglo-Saxon Ordo'. For the crown, see below, pp. 00-00/59-62.

143 Bouman, Sacring and Crowning, pp. 127-35, esp. 133-4, cf. 86-8, observing the role of secondary ceremonies in the formation of full royal ordines, and the tendency for the tradition of the insignia to find liturgical expression relatively late in this process. Such considerations help to explain the subsequent
} 
changes, in particular a new, more elaborate, anointing prayer, Omnipotens sempiterne deus, which appealed at greater length to Old Testament precedents for anointing, and emphasized the unity of the kingdom. ${ }^{144}$ Sta et retine formed the new prayer of enthronement; the three precepts followed thereafter, but the entire ritual was now framed by a new set of preliminaries. 145 Prior to his anointing, the king now issued a formal promise to the bishops of his kingdom, vowing to preserve 'canonical privilege and due law and justice, and that I will maintain protection as much as I am able with the Lord's assistance, just as a king should in his kingdom rightly maintain protection for each bishop and for the church entrusted to him'. 146 This was a significant development, since it added for the first time an element of conditionality to the ritual, with the subsequent anointing represented as formally conditional on the king's promise. ${ }^{147}$ The preliminaries were again derived from West Frankish practice of the second half of the ninth century. ${ }^{148}$ As Nelson has argued in relation to West Francia, it may be misleading to interpret such promises as the straightforward assertion or acceptance of clerical power; the point may have been rather to express goals or principles also accepted by lay observers of the ritual. ${ }^{149}$ Finally, the Second Ordo now included a queen's ordo of West Frankish origin, comprising anointing and the investitures of a ring and a crown. ${ }^{150}$ This was a significant development, since the First Ordo had lacked a queen's ordo, and that absence correlates suggestively with Asser's testimony on the low status accorded to the West Saxon 'king's wife'. ${ }^{151}$ Behind this new provision, there are strong grounds for detecting a major rethinking of the status of consort, a development compatible with the evidence advanced by Stafford for the higher status of queens in the tenth century. ${ }^{152}$

The compilation of the Second Ordo thus amounted to a grand and learned updating of the English ritual in the light of West Frankish practices. Later ninth-century West Francia

influence of the Erdmann Ordo and Ordo of Seven Forms, the tradition formulas of which found much re-use (ibid., pp. 132-6).

144 The text is available in the Appendix: see below, pp. 00-00/83-5 and 00-00/93-101.

145 Sacramentary of Ratoldus, ed. Orchard, p. 54, cf. pp. 47-8.

146 'Canonicum priuilegium et debitam legem atque iustitiam [...] et defensionem quantum potuero adiuuante domino exibebo, sicut rex in suo regno, unicuique episcopo et ecclaesiae sibi commissae per rectum exibere debet': Sacramentary of Ratoldus, ed. Orchard, pp. 47-8.

147 Emphasis has generally been placed on the later three-fold promise of the B-version: see Nelson, 'The Second English Ordo', pp. 369-71; Stafford, 'The Laws of Cnut and the History of Anglo-Saxon Royal Promises', pp. 187-8; Molyneaux, Formation of the English Kingdom, p. 188.

148 Erdmann Ordo 2-4 (Ordines, ed. Jackson, pp. 147). Cf. Ordo of Louis the Stammerer (877) 10-11 (Ordines, ed. Jackson, p. 20, cf. pp. 117-18). For the sequence of royal undertakings in later ninth-century West Francia, see above, p. 00/14, n. 96.

149 Nelson, 'The Lord's Anointed and the People's Choice', pp. 116-19. Cf. W. Ullmann, The Carolingian Renaissance and the Idea of Kingship (London, 1969), pp. 111-34.

150 Sacramentary of Ratoldus, ed. Orchard, pp. 55-6. Cf. Erdmann Ordo 23-32 (Ordines, ed. Jackson, pp. 1512).

151 See above, pp. 00-00/13-14.

152 Stafford, 'The Queen's Wife in Wessex', pp. 4-7, 15-18 and 20-27; P. Stafford, Queen Emma and Queen Edith: Queenship and Women's Power in Eleventh-Century England (Oxford, 1997), pp. 57-64, 165-9 and 197-206. 
has long been recognized as a place of great fertility and creativity in the use of royal anointing. ${ }^{153}$ Whereas the earlier phases of Carolingian rule had been punctuated by forms of anointing at papal hands, the mid ninth century saw a shift towards royal anointing by bishops, resuming the practice experimented with in 751 for Pippin III. ${ }^{154}$ As Nelson has explored, this development reflected the role of Hincmar, archbishop of Rheims (845-82), as a central player in West Frankish politics under Charles the Bald (843-77), in which royal ritual served to promote wider political consensus. ${ }^{155}$ As the author of ordines, archiepiscopal officiant, and commentator on kingship, Hincmar may be regarded as the founder of an entire legal-liturgical discourse on the responsibilities of anointed kings. Building on the existing Carolingian framework which represented kingship as fulfilling an office of divine service (ministerium), Hincmar developed anointing into a liturgical means of expressing wider expectations of rulership, in procedures increasingly dominated by bishops. ${ }^{156}$ By analogy with the examination and anointing of bishops-elect, bishops held special authority as consecrators for the mediation of the royal office. ${ }^{157}$ Hincmar's approach drew heavily on the practices of West Frankish royal assemblies, characterized by forms of mutual commitment between Charles the Bald and his fideles, in which the king typically recognized ecclesiastical privileges while undertaking for all orders to preserve 'for each their due law'. ${ }^{158}$ Hincmar's procedures for the anointing of Charles as king of Lotharingia in 869 and for Louis the Stammerer in 877 each incorporated as preliminaries similarly wide-ranging forms of undertaking by the king, responding to an episcopal enquiry: the undertaking given by Louis was explicitly cast as a promise, to preserve 'canonical privilege and due law and justice'. ${ }^{159}$ Royal anointing was seen to be conditional on the king's promise to preserve due law and ecclesiastical privileges. The parallel promise in the A-version of the Second Ordo amounted to the wholesale re-use of this Hincmarian mechanism.

It is possible to reconstruct the compilation of the Second Ordo with some precision. On the conventional reading of the evidence, it is clear that the compiler of the Second Ordo had in front of him not only the First Ordo but material from two Continental ordines of

\footnotetext{
153 P. E. Schramm, 'Die Krönung bei den Westfranken', in his Kaiser, Könige und Papste II, 140-68; Bouman, Sacring and Crowning; K. F. Morrison, The Two Kingdoms: Ecclesiology in Carolingian Political Thought (Princeton, NJ, 1964), pp. 178-238; Ullmann, The Carolingian Renaissance, pp. 71-110; J. M. WallaceHadrill, Early Germanic Kingship in England and on the Continent (Oxford, 1971), pp. 133-5 and 139.

154 Nelson, 'The Lord's Anointed and the People's Choice', pp. 114-20, cf. 102-3 and 108-11.

155 Nelson, 'Kingship, Law and Liturgy', pp. 137-9 and 149-55.

156 Ibid., pp. 155-71.

157 Ibid., pp. 137-46 and 162-6.

158 Ibid., pp. 146-55.

159 Ibid., pp. 149-55. Ordo of Charles the Bald (869) 9 (Ordines, ed. Jackson, p. 101); Ordo of Louis the Stammerer (877) 10-11 (Ordines, ed. Jackson, p. 20, cf. pp. 117-18).
} 
recent West Frankish origin. ${ }^{160}$ One source was the Erdmann Ordo, attested in the Pontifical of Sens (Saint Petersburg, National Library of Russia at Saint-Petersburg, MS lat. Q. v. I, No. 35), a widely consulted form of ritual heavily influenced by Hincmar's Ordo for Louis the Stammerer. ${ }^{161}$ The preliminaries of the Second Ordo came wholly from Erdmann: in addition, Erdmann supplied the blessing Deus qui populis, the formulas for the ring, sword, crown and sceptre, and the queen's ordo in its entirety, while the anointing prayer Omnipotens sempiterne Deus acted as an important source for the equivalent English prayer. ${ }^{162}$ Erdmann has generally been situated in the late ninth or early tenth century, with reference to the sequence of anointings conducted by archbishops of Sens: namely, the joint anointing and coronation of Louis III and Carloman at Ferrières by Ansegis of Sens, in September 879; the anointing of Odo by Walter of Sens on 29 February 888; the anointing of Robert I at Rheims by Walter of Sens on 29 June 922; and the anointing of Ralph by Walter at St-Médard, Soissons, on 13 July $923 .{ }^{163}$ In view of its sources, Erdmann clearly postdated 877, and probably also the papal crowning of Louis the Stammerer in 878; a further consideration arises from the Pontifical of Sens, often regarded as having been produced around the year 900, but tentatively dated by Bischoff to the third quarter of the ninth century. ${ }^{164}$ Bischoff's view could be reconciled by postulating the manuscript's production in the early part of the final quarter, which might place the drafting of Erdmann in the 880s. Problematically, very little is known of the form of the West Frankish anointings of 879 and

160 Nelson, 'The Second English Ordo', pp. 361-2; see also Bouman, Sacring and Crowning, pp. 117-21 and 133-4. The relationship of the A-version to its probable sources is laid out in the Appendix: see below, pp. 0000/102-5.

161 Ordines, ed. Jackson, pp. 142-53; see also Schramm, 'Die Krönung bei den Westfranken', pp. 159-65; Bouman, Sacring and Crowning, pp. 15-16, 82, 133 and 154-6. For the Pontifical of Sens, see Rasmussen, Les Pontificaux, pp. 89-135. Robinson, 'The Coronation Order in the Tenth Century', pp. 66-70, working before the discovery of Erdmann, had supposed that the compiler had drawn on the 877 Ordo, together with the 878 Ordo for the crowning of Louis the Stammerer by Pope John VIII (Ordines, ed. Jackson, pp. 127-8). Erdmann is generally closer textually to the Second Ordo; that it had been used by the compiler is further suggested by the queen's ordo and by certain other formulas which do not occur in the 877 and 878 material.

162 The overall relationship, and the composite nature of the anointing prayer, are shown in the Appendix: see below, pp. 00-00/93-105.

163 See the remarks of P. Gasnault, reported in G. Lobrichon, 'Nouvelles recherches sur le rituel pontifical de Sens au IX ${ }^{\mathrm{e}}$ siècle', Bulletin de la Société Nationale des Antiquaires de France 1992 (1994), 191-200, at 199; Lanoè, 'L'ordo de couronnement', pp. 43-4; Nelson, 'Early Medieval Rites of Queen-Making', pp. 309-11; S. Bobrycki, 'The Royal Consecration Ordines of the Pontifical of Sens from a New Perspective', Bulletin du centre d'études médiévales d'Auxerre 13 (2009), 131-42. For these anointings, see R.-H. Bautier, 'Sacres et couronnements sous les Carolingiens et les premiers Capétiens: Recherches sur la genèse du sacre royal français', Annuaire-Bulletin de la Société de l'Histoire de France, Année 1987 (1989), 7-56, at 45-50, with the comments of Nelson, 'Early Medieval Rites of Queen-Making', pp. 310-11. For the possible West Frankish/Lotharingian anointing of Charles the Fat on 20 May 885 by Geilo, bishop of Langres, at Grand in Lotharingia, see S. MacLean, Kingship and Politics in the Late Ninth Century: Charles the Fat and the End of the Carolingian Empire (Cambridge, 2003), pp. 126-7 and 144-60.

164 B. Bischoff, Katalog der festländischen Handschriften des neunten Jahrhunderts (mit Ausnahme der wisigotischen), 3 vols. (Wiesbaden, 1998-2014) III, 84-5; Lobrichon, 'Nouvelles recherches sur le rituel pontifical de Sens', pp. 192-3; Jackson, Ordines, p. 26; Rasmussen, Les Pontificaux, pp. 93-4. 
888 , since the surviving texts principally relate to the preliminaries of each ceremony. ${ }^{165}$ The Ordo for Odo includes a blessing and anointing prayer, but the rite is fragmentary and problematic. ${ }^{166}$ A further complication arises from the queen's ordo in Erdmann: Nelson has postulated the anointing of Odo's queen, Theodrada, in 888, a likely hypothesis, yet it seems doubtful that Erdmann represents rites prepared for a specific occasion. ${ }^{167}$ The short, generic nature of the episcopal petition and royal promise in Erdmann rather suggests a standardized form of ritual, probably reflecting Sens usage in the period after 878 .

The other main source identified for the Second Ordo has been the Ordo of Seven Forms, an influential ordo of probable West Frankish origin, best known from its preservation in a thirteenth-century pontifical from the monastery of Stavelot in the diocese of Liège. 168 The Ordo of Seven Forms here comprised two anointing prayers, tradition formulas for a crown, sceptre, ring and sword, and the enthronement prayer, Sta et retine, together with a queen's ordo. That Seven Forms had a much earlier origin is suggested by the anointing prayer, Omnipotens eterne Deus, a variant on that in Erdmann, and confirmed by the fact that many of the Seven Forms formulas were subsequently incorporated into the full German Ordo, as represented in the Romano-Germanic Pontifical. ${ }^{169}$ As Bouman commented, the skeletal nature of Seven Forms suggests that it may have functioned as a collection of formulas to be used in combination with other material. ${ }^{170}$ Clearly postdating 877 and Erdmann, Seven Forms has posed more problems of interpretation in view of its relative distance from the main path of West Frankish development, and has generally been left to

\footnotetext{
165 Ordines, ed. Jackson, pp. 130-8.

166 Jackson, Ordines, p. 26.

167 Nelson, 'Early Medieval Rites of Queen-Making', pp. 310-11. Cf. Jackson, Ordines, p. 27; Bobrycki, 'The Royal Consecration Ordines', pp. 134-5.

168 Brussels, Bibliothèque royale de Belgique, 2067-73. Ordines, ed. Jackson, pp. 154-67; see also Erdmann, Forschungen zur politischen Ideenwelt, pp. 87-9, cf. 56-9; Schramm, 'Der Ablauf der deutschen Königsweihe nach dem "Mainzer Ordo" um 960', in his Kaiser, Könige und Papste III, 59-107, at 90-2, cf. 61. Bouman, Sacring and Crowning, pp. 21-2, 82-4, 133-4, 137-8 and 154-6.

169 Bouman, Sacring and Crowning, pp. 114-16, cf. 30-1, 82, 137, 154-6 and 159; see also Jackson, Ordines, pp. 27-9. Le pontifical romano-germanique, ed. Vogel and R. Elze I, 246-61; Die Ordines für die Weihe und Krönung des Kaisers und der Kaiserin, ed. R. Elze, MGH Fontes 9 (Hanover, 1960), 6-9. The dating of the full German Ordo depends on the view taken of the PRG, conventionally dated c. 960, now subject to debate arising from the work of Parkes: see above, p. 00/21, n. 139. The account of the coronation of Otto I in 936 by Widukind of Corvey, writing in the 960s, relates to the Early German Ordo: see Erdmann, Forschungen zur politischen Ideenwelt, pp. 65-9; Bouman, Sacring and Crowning, p. 84; cf. D. A. Warner, 'Comparative Approaches to Anglo-Saxon and Ottonian Coronations', England and the Continent in the Tenth Century, ed. Rollason et al., pp. 275-92, at 282-6, with references. For the addition of a text of the Early German Ordo $c$. 1000 to Wolfenbüttel, Herzog August Bibliothek, Cod. Guelf. 7.2 Aug. $4^{\circ}$ (Bavaria, s. $x^{\text {in }}$ ), then at Mainz, see Parkes, The Making of Liturgy, pp. 142-3, 155 and 158, cf. 135-42; it would, however, be hazardous to infer from this that the Early German Ordo remained in use. For the full German Ordo, attested in five recensions, see Erdmann, Forschungen zur politischen Ideenwelt, pp. 54-63; Bouman, Sacring and Crowning, pp. 32-7, 83-4, 159-60 and 176-87, esp. p. 37, observing that all five recensions are attested in $P R G$ manuscripts written before $c$. 1050. The distribution would be compatible with a later tenth-century date for the compiling of the Ordo.

170 Bouman, Sacring and Crowning, p. 155.
} 
float uncertainly in the late ninth or early tenth centuries; its complex textual transmission and inter-relationship with English, German and other European rites raises further issues, which will be returned to below. ${ }^{171}$

\section{Existing arguments on the dating of the Second Ordo}

The overall character of the A-version of the Second Ordo, as a major rethinking of the English ritual, highlights the desirability of contextualizing it more closely. Earlier work has proposed alternative scenarios for the drafting of the Second Ordo. Nelson originally dated the Second Ordo to the latter part of King Alfred's reign, making connections with Alfred's rule over western Mercia and his styling in diplomas as king over 'Angles' and 'Saxons'. ${ }^{172}$ The inclusion of a queen's ordo pointed in the same direction, since Edward the Elder had married in his father's lifetime, and appears to have contracted his second marriage, to Elfflæd, at around the time of his accession. There was therefore the good possibility that Ælfflæd had been anointed on the occasion of Edward's consecration on 8 June 900, whereas Æthelstan, the other king under consideration, appears never to have married. ${ }^{173}$

More recently, however, Nelson has presented revised arguments prompted by Orchard's new edition of the Leofric Missal. The core of that codex, 'Leofric A', is a combined sacramentary and pontifical executed in a Continental Caroline minuscule of the second half of the ninth century, showing strong Insular influences. 'Leofric A' has conventionally been regarded as having been written in the region of Arras or Cambrai, and then imported into England, to Christ Church, Canterbury, by the 920s. ${ }^{174}$ Orchard has suggested on the basis of the liturgical content, however, that it had been written around the year 900 for an English archbishop, by implication, Plegmund (890-923).175 Nelson's inference is that the First Ordo must have continued to be current in the early tenth century since, if 'Leofric A' had been tailor-made for Plegmund, then the inclusion of the First Ordo would not have made sense if the Second Ordo had already been drafted. ${ }^{176}$ Building on the reasoning of Derek Turner and others, Nelson has suggested an alternative context for the Second Ordo in the politics of Æthelstan's accession. ${ }^{177}$ Dying on 17 July 924, Edward the Elder was initially succeeded by Ælfweard, his eldest son by Ælfflæd, but Ælfweard himself

\footnotetext{
171 See below, pp. 00-00/28-35.

172 Nelson, 'The Second English Ordo', pp. 365-6.

173 Ibid., pp. 366-7.

174 Dumville, 'On the Dating', p. 50; idem, Liturgy, pp. 39-43 and 82.

175 Orchard, Leofric Missal I, esp. 20, 83, 105 and 131.

176 Nelson, 'The First Use of the Second Anglo-Saxon Ordo', pp. 118-23.

177 Ibid., pp. 123-4. Turner, Claudius Pontificals, pp. xxxii-xxxiii. Hohler, 'Some Service Books', p. 68; Wormald, Making of English Law I, 447, n. 114; cf. also S. Foot, Athelstan: the First King of England (Yale, CT, 2011), pp. 73-7; Molyneaux, Formation of the English Kingdom, p. 55. For other views favouring Æthelstan, see Brooks, Canterbury, p. 164; G. Garnett, 'Coronation', The Wiley Blackwell Encyclopaedia, ed. Lapidge et al., pp. 125-6, at 125.
} 
died in early August. ${ }^{178}$ It is conceivable that Æthelstan had initially been recognized as king in Mercia only, that Ælfweard had briefly ruled in Wessex, and that only subsequently had Æthelstan's authority been recognized in Wessex as well as Mercia. ${ }^{179}$ Certainly, there are signs that Æthelstan, a 'Mercian' candidate for kingship, faced early opposition in Wessex, while the timing of his anointing, on 4 September 925, might suggest deliberate or necessary delay. ${ }^{180}$ Æthelstan's early diplomas, moreover, claimed rule over the 'kingdom of the Anglo-Saxons'. ${ }^{181}$ Hence, Nelson has suggested, the anointing prayer of the Second Ordo, with its references to two peoples and to unity, might make sense in the context of Ethelstan's efforts to impose his rule. 182

These arguments are ingenious, and, if one accepts Orchard's view of the Leofric Missal, they follow inexorably from it. Yet Orchard's case is far from compelling. The conventional view has been to regard 'Leofric A' as a Continental manuscript written in the dioceses of Arras or Cambrai, in view of the script, decoration and honour accorded to St Vedastus. ${ }^{183}$ Orchard acknowledges these features, but goes on to suggest some 'English' symptoms: namely, the book's penitential ordo for Ash Wednesday; the existence of separate sanctoral; the treatment of St Mark's Day as 18 May; the prayer Pater sancte among blessings for the consecration of a bishop; a prayer for the consecration of the new fire on Holy Saturday; prayers for consigning the pallium; and the inclusion of the First Ordo. ${ }^{184}$ Although each argument might appear to suggest an English context, none is decisive. ${ }^{185}$ For example, the separate sanctoral, although unusual, has some Italian and Frankish parallels. ${ }^{186}$ There are grounds for thinking that the alternative day for St Mark was known outside England. ${ }^{187}$ Continental transmission of the First Ordo is independently attested. Furthermore, 'Leofric A' contains no firm evidence indicating production for an archbishop; this contrast with additions subsequently made to the manuscript at Canterbury from the 920s onwards, which attest to an English and archiepiscopal context. 188 The case for a Continental origin receives support from early additions to 'Leofric A', which suggest the book's presence on the

\footnotetext{
178 For these events, see below, pp. 00-00/64-5.

179 Keynes, 'England, c. 900-1016', p. 467; Foot, Athelstan, pp. 38-40.

180 S 394 (CantStA 26). Keynes, 'England, c. 900-1016', pp. 467-8; Foot, Athelstan, pp. 40-1.

181 Keynes, 'England, c. 900-1016', p. 468

182 Nelson, 'The First Use of the Second Anglo-Saxon Ordo', pp. 124-5.

183 Gneuss, Handlist, no. 585; Ker, Catalogue, pp. 378-9 (no. 315); E. M. Drage, 'Bishop Leofric and Exeter Cathedral Chapter, 1050-72: a Reassessment of the Manuscript Evidence' (unpubl. DPhil dissertation, Univ. of Oxford, 1978), pp. 72, 92 and 95; Dumville, Liturgy, p. 82.

184 Orchard, Leofric Missal I, 23-9, 39-43, 46-7, 53-6, 74-80, 86-8 and 99-108.

185 See Pratt, English Coronation Ordines.

186 Orchard, Leofric Missal I, 46-7.

187 Ibid., pp. 52-3.

188 For these additions, see D. N. Dumville, English Caroline Script and Monastic History: Studies in Benedictinism, A.D. 950-1030 (Woodbridge, 1993), pp. 95-6.
} 
Continent before the 920s. ${ }^{189}$ Of particular importance, as Dumville has highlighted, is an addition on the first leaf (9r17-21), comprising lists of Nomina uiuorum and Nomina mortuorum. The inclusion of Odalgarius, bishop of Clermont-Ferrand (d. 891) and Madalbertus, bishop of Bourges (d. 910), indicates that the addition had been made after 910; the script would be consistent with the lists having been added in south-western Francia. 190 These features seem sufficient to rule out the idea that 'Leofric A' had been produced for Plegmund; it follows that the manuscript has no bearing on the date of the Second Ordo.

\section{THE LEIDEN ORDO AND ITS RELATIONSHIP TO THE SECOND ORDO}

The best hope of contextualizing the Second Ordo more closely lies in its relationship to West Frankish sources. Issues relating to the Ordo of Seven Forms permit a fresh assessment. A further problem with that $O r d o$ is that it survives in two versions: most attention has been paid to the main, fuller version of the text, which includes the full set of tradition formulas and the queen's ordo, but there is also a shorter version, first identified by Lanoè, and attested in Leiden, Rijksuniversiteit Bibliotheek, Voss. lat. Q. 13, fols. 15-30, a fragment of a Gregorian sacramentary written in north-eastern France around the year 1000, probably deriving from the province of Sens. ${ }^{191}$ The shorter version is here termed the Leiden Ordo, in order to distinguish it from the full Ordo of Seven Forms. Lanoè sought to connect the Leiden Ordo with the coronation of Charles the Bald as king of Aquitaine in 848, but the anointing prayer clearly postdates 877 ; the issue of dating is considered further below. ${ }^{192}$ The Leiden Ordo covers the king's anointing only, and has formulas for the crown and sceptre (uirga), lacking those for the ring and sword. Although Leiden and Seven Forms lack substantial rubrics, they each contain, in sequence, all the liturgical elements that had come to be seen as necessary for royal anointing by the late ninth century. That Leiden in particular should be regarded as a meaningful sequence of formulas eceives support from the manuscript title, CONSECRATIO REGIS IN REGEM ('The consecration of a king as king'). In its shorter format, the Leiden Ordo bears a relationship to two further ordines which have been

\footnotetext{
189 9r1-17 and 336v (the first and last leaves of 'Leofric A'): liturgical forms executed in a Continental Caroline minuscule exhibiting Insular influences, thinly preserved, broadly datable to the late ninth or early tenth century. The further addition, 9r17-21, strongly implies that 9r1-17 had been written before the 'Leofric A' reached England. 253v1-13: an addition at the end of a quire in the same type of script by a different hand. See Drage, 'Bishop Leofric', pp. 75, 79 and 80. Cf. Orchard, Leofric Missal I, 133, who problematically identifies 9r1-17 and 253v1-13 as the work of an English scribe (his 'Scribe A') and equates these with another, genuinely English addition, executed in hybrid Insular Caroline (210v-211v: see Drage, 'Bishop Leofric', p. 78). Cf. also Orchard, Leofric Missal II, 467, regarding 336v as English work of the mid tenth century.

190 Dumville, Liturgy, p. 42; cf. Orchard, Leofric Missal I, 135 (for 9r1-17, see the preceding footnote).

191 Edited by Lanoè, 'L'ordo de couronnement', pp. 59-64; MS A in Jackson's edition of the Ordo of Seven Forms (Ordines, pp. 156-67). Cf. Jackson, Ordines, pp. 28-9 and 155-6.

192 See below, pp. 00-00/37-43.
} 
considered witnesses to the broader Seven Forms tradition: the Ordo of Burgundy, seemingly relating to the region of Provence and Jurane Burgundy, the earliest manuscript of which is twelfth-century; and an ordo of Portuguese origin, preserved in a thirteenth-century pontifical from the archbishopric of Braga. ${ }^{193}$

The Leiden Ordo is compared with the Second Ordo, together with the Ordo of Burgundy and the full Ordo of Seven Forms, in the table below:

$\begin{array}{llll}\begin{array}{l}\text { Leiden Ordo (ed. } \\ \text { Lanoè: cf. also }\end{array} & \begin{array}{l}\text { Ordo of Burgundy } \\ \text { (ed. Elze) }\end{array} & \begin{array}{l}\text { Seven Forms } \\ \text { (Ordines, ed. } \\ \text { Ordines, ed. }\end{array} & \begin{array}{l}\text { Relevant elements } \\ \text { (n the A-version of }\end{array} \\ \text { Jackson, pp. 159-64, } & & \text { 67, MS E) } & \text { the Second Ordo }\end{array}$

Te deum and the king's professio

\begin{tabular}{|c|c|c|c|}
\hline Anointing & Anointing & Anointing & Omnipotens \\
\hline $\begin{array}{l}\text { Omnipotens aeterne } \\
\text { deus }\end{array}$ & $\begin{array}{l}\text { Omnipotens eterne } \\
\text { deus }\end{array}$ & $\begin{array}{l}\text { Omnipotens eterne } \\
\text { deus }\end{array}$ & $\begin{array}{l}\text { sempiterne deus } \\
\text { [borrows in part } \\
\text { from Omnipotens } \\
\text { aeterne deus: see } \\
\text { Appendix, below] }\end{array}$ \\
\hline Deus dei filius & Deus dei filius & Deus dei filius & Deus dei filius \\
\hline Crown & Crown & Crown & \\
\hline Accipe igitur & Accipe igitur & Accipe coronam & \\
\hline coronam regni & coronam regni & regni & \\
\hline Sceptre & Sceptre & Sceptre & \\
\hline \multirow[t]{6}{*}{ Accipe uirgam } & Accipe uirgam & Accipe uirgam & Accipe uirgam \\
\hline & & Ring & \\
\hline & & Accipe regie & \\
\hline & & dignitatis anulum & \\
\hline & & Sword & \\
\hline & & Accipe gladium & \\
\hline Enthronement & Enthronement & Enthronement & \\
\hline Sta et retine & Sta et retine & Sta et retine & Sta et retine \\
\hline
\end{tabular}

\footnotetext{
193 R. Elze, 'Königskrönung und Ritterweihe: Der Burgundische Ordo für die Weihe und Krönung des Königs und der Königin', Institutionen, Kultur und Gesellschaft: Festschrift für Josef Fleckenstein, ed. L. Fenske, W. Rösener and T. Zotz (Sigmaringen, 1984), pp. 327-42, which includes an edition (pp. 333-40); Bouman, Sacring and Crowning, pp. 22-3 and 158-9. R. Elze, 'Ein Krönungsordo aus Portugal', Memoriam Sanctorum Venerantes: Miscellanea in onore di Mongisnor Victor Saxer, Studi di Antichità Christiana 48 (Vatican City, 1992), 323-34, at 329-34 (text).
} 


\section{Deus qui uictrices \\ Moysi manus}

\section{Deus inenarrabilis}

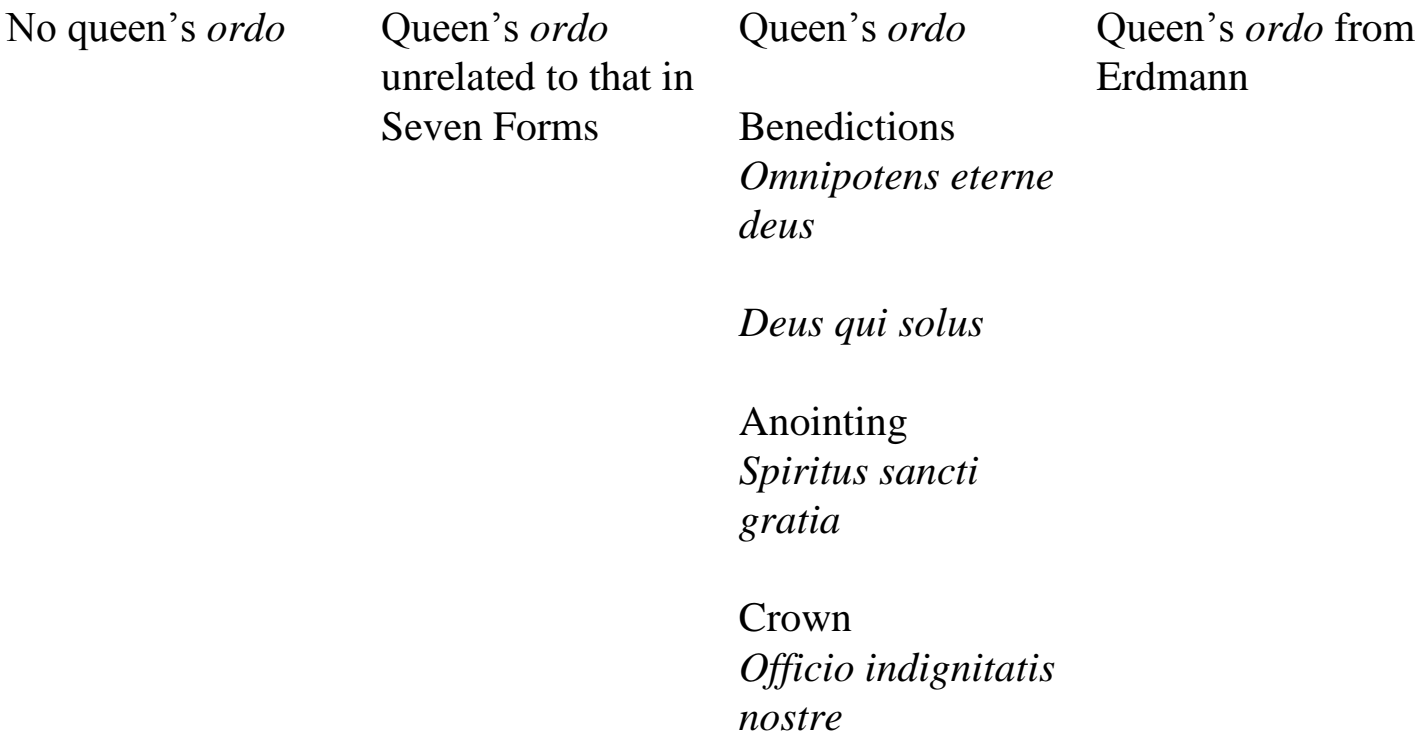

The arrangement of Leiden is striking, since the Second Ordo shows knowledge of all the elements present, with the exception of the crown formula; the Second Ordo similarly lacks the ring and sword formulas, whereas the compiler drew on Erdmann for the queen's ordo. ${ }^{194}$ Writing before the discovery of the Leiden Ordo, but in awareness of the Ordo of Burgundy, Bouman hypothesized that behind Seven Forms may have lain 'a smaller collection in which not all the items of the definitive series figured', and that this 'imperfectly developed' version of Seven Forms may have been known to the compiler of the Second Ordo. ${ }^{195}$ The Leiden Ordo answers Bouman's suspicions uncannily, and in the light of Lanoé's discovery, Jackson has suggested that the Second Ordo had not been influenced by Seven Forms, but rather a precursor to the Leiden and Portuguese Ordines. ${ }^{196}$ Yet the Leiden Ordo adds a major complication, not commented on by Jackson, in the form of its anointing prayer, Omnipotens aeterne deus. This also makes provision for kingship of two peoples, in this case the 'Franks' and 'Aquitanians', having the readings regem francorum et equitanorum pariter ('king of the Franks and Aquitanians equally') and ecclesiamque ecquitanam et frantiam (sic: 'and the church in Aquitaine and Francia'), and making subsequent reference to 'both these peoples' (utrorumque horum populorum). ${ }^{197}$ These readings can be compared with the anointing

\footnotetext{
194 In the published version of his paper, Lanoè acknowledges the significance of the queen's ordo in the Second Ordo: 'L'ordo de couronnement', p. 51, n. 36. Cf. Jackson, Ordines, pp. 155-6.

195 Bouman, Sacring and Crowning, p. 134, cf. pp. 21, 117-18, 132-3 and 155.

196 Jackson, Ordines, p. 29.

197 Lanoé, 'L'ordo de couronnement', p. 61. The Portuguese Ordo from the archbishopric of Braga similarly preserves the notion of rule over two peoples in the reading 'utroque horum populorum' and 'ecclesiamque
} 
prayers in the Second Ordo and the Ordo of Seven Forms in the Appendix. ${ }^{198}$ The proximity of the Leiden readings to those reconstructed for the A-version of the Second Ordo poses a significant problem, since, for as long as the Ordo of Seven Forms has been regarded as the source, the references to two peoples in the Second Ordo have been interpreted as additions made by the compiler to adapt the anointing prayer to an English context.

Nelson has acknowledged the Leiden Ordo as an issue and has attempted to explain the references to kingship of two peoples in terms of the subsequent influence of the Second Ordo. Her hypothesis is that the original references to two peoples had concerned the 'Angles' and 'Saxons' in the A-version of the Second Ordo, and that the idea then found its way into the Leiden Ordo through the subsequent Continental influence of the Second Ordo, being adapted to refer to the 'Franks' and 'Aquitanians'. ${ }^{199}$ Yet there is a problem since, when compared with the Ordo of Seven Forms, Leiden proves to be textually closer than Seven Forms to the equivalent sections of the A-version of the Second Ordo: this can be shown at the level of individual readings. Significantly, Second Ordo readings agreeing with the Leiden Ordo against Seven Forms are not restricted to the anointing prayer, Omnipotens sempiterne deus, but also occur in Accipe uirgam. ${ }^{200}$

\section{Omnipotens sempiterne deus}

Ratold: moyse et iosue populo tuo prelatis

tuo Leiden, Ordo of Burgundy and Braga; tuo omitted Seven Forms and PRG

Ratold: tibi in omnibus complaceat

complaceat Leiden, Ordo of Burgundy and Braga; placeat Seven Forms and PRG

Ratold: sed ad pristine fidei pacisque concordiam

pristine Leiden (text not present in Ordo of Burgundy or Braga); uere Seven Forms and PRG

Ratold: condigno amore glorificatus

glorificatus Leiden, Braga and PRG (text not present in Ordo of Burgundy); glorificetur

\section{Seven Forms}

Ratold: de hostibus feliciter

de hostibus feliciter Leiden and Braga (text not present in Ordo of Burgundy); feliciter Seven

Forms and PRG

\section{Accipe uirgam}

Ratold: errantes uiam doce. lapsisque manum porrige

Francie uel Yspanie', cf. 'in regem Francorum et Burgundionum Yspanorum pariter': Elze, 'Ein Krönungsordo aus Portugal', p. 330-1.

198 See below, pp. 00-00/93-101.

199 Nelson, 'Early Medieval Rites of Queen-Making', p. 311, n. 54; see also her review of Ordines, ed. Jackson in EHR 112 (1997), 1230-1.

200 Cf. Lanoè, 'L'ordo de couronnement', p. 49. 
errantibus uiam docere. lapsisque manum porrigere Leiden and Ordo of Burgundy; errantibus uiam pandere. lapsis manum porrigere Seven Forms and $P R G$

\section{Sta et retine}

Ratold: et quanto clerum sacris altaribus propinquiorem prospicis prospicis Braga; perspicis Leiden, Seven Forms and PRG

The instance from Sta et retine could reflect independent variation but is included for completeness. It must be remembered that the Second Ordo draws only on formulas which are present in the Leiden Ordo. The combination of readings and the pattern of borrowing makes a text very close to Leiden, rather than Seven Forms, the more likely candidate for the source used in the Second Ordo.

Some of the problems posed by the Leiden Ordo have been recognized by Orchard in his edition of the Sacramentary of Ratold. Noting the complexity of comparison between the Second Ordo and West Frankish ordines, including Leiden, Orchard floats the idea that parts of what appear to be Continental ordines, including Seven Forms, might have been of English origin. ${ }^{201}$ The suggestion might seem impossibly radical, but, given the textual proximity of Leiden and the Second Ordo, puts forward the main alternative to the hypothesis that Leiden had acted as the source for the Second Ordo: namely, that the Second Ordo had acted as the source from which Leiden was subsequently derived. The matter can be approached by means of the table in the Appendix, which lays out the anointing prayer in Leiden alongside the Second Ordo and Erdmann, presumed to be the source for certain sections of the English anointing prayer. ${ }^{202}$ Ultimately, the comparison indicates a strong case for the priority of the Leiden Ordo over the Second Ordo. The shorter nature of the Leiden Ordo, as reflected in the Ordo of Burgundy and the Portuguese Ordo, suggests that Leiden is earlier than the fuller Ordo of Seven Forms. The respective versions of the anointing prayer in Leiden and Seven Forms are at the very least consistent with this view. ${ }^{203}$ No reading is wholly decisive, but the Seven Forms prayer contains nothing which is not also present in the Leiden prayer, and might be credibly interpreted as an edited version of the Leiden prayer, in which the references to two peoples had been removed and the application of the prayer made more neutral. In addition, the Leiden Ordo could not have been derived in its entirety from the Second Ordo because the crown formula, present in Leiden, does not feature in the Second Ordo. Such a scenario is also inherently unlikely, because the Second Ordo includes two Leiden formulas complete, Deus dei filius and the uirga formula; one would have to envisage a putative compiler extracting from the Second Ordo only those elements not derived from

\footnotetext{
201 Orchard, Sacramentary of Ratoldus, pp. cxxx-cxxxi.

202 See below, pp. 00-00/93-101.

203 These may also be compared by means of the Appendix: see below, pp. 00-00/93-101.
} 
Erdmann or the First Ordo. Conversely, access by the compiler of the Second Ordo to a text very like Leiden seems likely because, with the exception of the crown formula, all other elements of Leiden are represented.

When considered in isolation, the relative priority of the anointing prayers in Leiden and the Second Ordo, including the references to two peoples, might seem difficult to establish. This is especially the case given the passage of unique agreement between the two prayers, against Seven Forms, immediately preceding the reading 'utrorumque horum populorum':

Leiden: contraque omnes uisibiles. et inuisibiles hostes eidem potenter regaliterque tuae uirtutis regimen amministret. ut francorum regnum non deserat. sed ad pristine fidei pacisque concordiam eorum animos te opitulante reformet. ut utrorumque horum populorum debita subjectione fultus. condigno amore glorificatus ('and like a mighty king administer the rule of your power against all enemies, visible and invisible, that he should not abandon the kingdom of the Franks, but by your help reform their minds to the concord of true faith and peace, that, strengthened with the due obedience and glorified with the condign love of both these peoples')

Ratold: contraque omnes uisibiles et inuisibiles hostes idem potenter regaliterque tuae uirtutis regimen amministret, ut regale solium uidelicet francorum sceptra non deserat, sed ad pristine fidei pacisque concordiam eorum animos te opitulante reformet, ut utrorumque horum populorum debita subiectione fultus, condigno amore glorificatus ('and like a mighty king administer the rule of your power against all enemies, visible and invisible, that he should not abandon the royal throne namely the sceptres of the Franks, but by your help reform their minds to the concord of true faith and peace, that, strengthened with the due obedience and glorified with the condign love of both these peoples')

Seven Forms: contraque omnes uisibiles et inuisibiles hostes eidem potenter regaliterque tue uirtutis regimen administret et ad uere fidei pacisque concordiam eorum animos te opitulante reformet, ut horum populorum debita subiectione fultus, cum digno amore glorificetur [glorificatus $P R G$ ] ('and like a mighty king administer the rule of your power against all enemies, visible and invisible, and by your help reform their minds to the concord of true faith and peace, that, strengthened with the due obedience he might be glorified with the condign love of these peoples')

Priority here seems difficult to establish; Leiden guards against the king abandoning his kingdom, whereas the slightly awkward treatment of 'regale solium' and 'sceptra' in the Second Ordo, in apposition, allows the clause to envisage the king abandoning his throne 
specifically. ${ }^{204}$ Special significance should therefore be assigned to the next passage, which presents a unique instance of agreement between Leiden and Seven Forms, against the Second Ordo.

Ratold: ut utrorumque horum populorum debita subiectione fultus, condigno amore glorificatus, per longum uitae spatium paternae apicem gloriae tua miseratione unatim stabilire et gubernare mereatur. tuae quoque protectionis galea munitus, et scuto insuperabili iugiter protectus ('that, strengthened with the due obedience and glorified with the condign love of both these peoples, he might deserve by your mercy through a lengthy span of life to establish and govern the apex of paternal glory unitedly; also defended with the helmet of your protection, continually protected with your invincible shield')

Leiden and Seven Forms: ut [utrorumque Leiden] horum populorum debita subjectione fultus. condigno amore glorificatus [glorificetur et Seven Forms; glorificatus PRG] ad paternum decenter solium tua miseratione conscendere mereatur. tuae quoque protectionis galea munitus. et scuto insuperabili iugiter protectus ('that, strengthened with the due obedience and glorified with the condign love of [both] these peoples, he might deserve by your mercy to proceed fittingly to the paternal throne; also defended with the helmet of your protection, continually protected with your invincible shield')

This passage shows beyond reasonable doubt that the Leiden text could not have been derived in its entirety from the Second Ordo. There are, moreover, good grounds for thinking that Leiden here preserves an earlier reading. Leiden expresses, as the Second Ordo does not, a connection between the throne and paternal inheritance which occurs prominently in the enthronement formula Sta et retine, another element shared between the two ordines. ${ }^{205}$ If Leiden had been earlier, the agreement between the Leiden and Seven Forms readings would be readily explained.

These considerations strengthen the case for Leiden as the source for the Second Ordo, since, in order to account for the Leiden anointing prayer, they leave two unlikely scenarios as the only alternatives. Firstly, one would have to envisage that the compiler of the Second Ordo had access to an ordo textually near-identical to Leiden but lacking the

\footnotetext{
204 Cf. Bouman, Sacring and Crowning, pp. 118-19, who regarded the anointing prayer of the Second Ordo as 'most curious' and 'far from elegant'. For the vestige of rule over two peoples in the Portuguese Ordo, see above, pp. 00-00/30-1, n. 197.

205 'Sta et retine amodo locum. quem hucusque paterna successione tenuisti. hereditario iure tibi delegatum [...] Quatinus mediator dei et hominum. te [...] in hoc regni solio confirmet' ('Stand and hold fast from henceforth the place, which hitherto you have held by paternal succession, having been assigned to you by hereditary right [...] That the mediator of God and men may strengthen you on this throne of the kingdom': Lanoé, 'L'ordo de couronnement', p. 64; Ordo of Seven Forms 8 (Ordines, ed. Jackson, pp. 163-4) has the same text with minor variants.
} 
references to two peoples; that the references to two peoples were then reimported from the A-version of the Second Ordo back to the same hypothetical Continental ordo; and that, in such a process, the Second Ordo reading 'per longum uitae spatium paternae apicem gloriae tua miseratione unatim stabilire et gubernare mereatur' was nevertheless rejected (to form the Leiden $O r d o$ ). Or, secondly, one would need to envisage that the compiler had access to an ordo similar to Leiden but with an anointing prayer closer to the Seven Forms readings; that all the relevant variants, along with the references to two peoples, were then reimported from the A-version of the Second Ordo; and that, in such a process (which otherwise replicated variants present in the A-version of the Second Ordo), the Second Ordo reading 'per longum uitae spatium [...] mereatur' was nevertheless rejected (to form the Leiden Ordo). Either scenario requires not only a hypothetical Continental ordo which has left no trace, but the involvement of such an ordo in two stages of the transmission in ways which defy good sense.

The identification of the Leiden Ordo, rather than Seven Forms, as the source for the Second Ordo is an arresting finding. It indicates that the idea of an anointing prayer enshrining kingship over two peoples was not original to England but was borrowed from a West Frankish ordo and adapted to an English context. Since that context can be identified with some confidence as the 'kingdom of the Anglo-Saxons' in the period $880 \mathrm{x} 925$, it reveals that this expression of rule over the bipartite kingdom drew on external intellectual resources. This is doubly significant in view of the indications that the term Angli Saxones had originally been generated in a Continental context, as a means of distinguishing the Germanic inhabitants of Britain from the Continental Saxons. ${ }^{206}$ The finding adds to the understanding of the Second Ordo as a complex amalgam of English and Continental traditions, rendering it intelligible as a work of textual splicing. The compiler's work involved little fresh composition but the intelligent combining of existing sources: the First Ordo formed the backbone onto which the Continental ordines, Erdmann and Leiden, were grafted. 207 The discrete nature of the Continental source material might suggest access to a

\footnotetext{
206 W. H. Levison, England and the Continent in the Eighth Century (Oxford, 1946), p. 92, n. 1; Keynes, 'King Alfred and the Mercians', p. 25.

207 The probable editing process may be judged from the Appendix: see below, pp. 00-00/102-5. In addition to the three main sources, the compiler also appears to have had access to certain elements of the Ordo used for the anointing of Charles the Bald as king of Lotharingia in 869, comprising the blessing spoken by Hincmar of Rheims, Extendat omnipotens dominus dexteram, the archbishop's anointing prayer, Coronet te dominus corona gloriae, and the blessing, Et qui te uoluit: Ordo of Charles the Bald (869) 24-7 and 29-31 (Ordines, ed. Jackson, pp. 107-8). Cf. also Ordo of Louis the Stammerer (877) 20-1 and 25-8 (Ordines, ed Jackson, pp. 122-3). Hincmar's blessing and anointing prayer are among elements of the 869 Ordo for which Jackson has postulated earlier origins. On the basis of tone and content, he has argued that the 869 Ordo drew upon prayers associated with the ceremony of reconciliation to the Church performed for Louis the Pious at Metz in 835: R. A. Jackson, 'Who Wrote Hincmar's Ordines?', Viator 25 (1994), 31-52. Aspects of the proposed identification appear speculative, however, and it may be safer to regard the formulas as material strongly associated with Hincmar, though of uncertain origin. The 869 Ordo is known to have been transmitted alongside other Hincmarian ordines: see the following footnote. Given the restricted nature of the elements
} 
collection of ordines, rather than to multiple pontificals, a type of 'dossier' exemplified by a now lost Liège manuscript, which once contained the Ordines for Judith (856), Ermentrude (866), Charles the Bald (869) and Louis the Stammerer (877). ${ }^{208}$ All the tradition formulas from Erdmann were incorporated (ring, sword, crown and sceptre), apart from that for the baculus, where the uirga formula from Leiden was preferred. The intention might possibly have been to avoid the baculus, which had assocations with the episcopal office, but the editing might be more economically explained by the fuller nature of the uirga formula, which avoided thematic overlap with Erdmann formula for the sceptre. ${ }^{209}$ The finding renders less likely the suggestion, once put forward by George Garnett, that the compiler may have drawn on a lost West Frankish ordo, in which Erdmann and Seven Forms had already been combined. ${ }^{210}$ Leiden would account, with a high degree of precision, for the text of those elements derived from it, and the prompting of such a central detail as the idea of rule over two peoples would be harder to explain if the compiler had not had direct access. The handling of regalia, each of which typically has two prayers in the Second Ordo, one accompanying and one following the investiture, also implies the work of a compiler drawing directly on the First Ordo, Erdmann and Leiden. ${ }^{211}$

Leiden may have offered several attractions, beyond the uirga formula and additional anointing prayer Deus dei filius. The conceptual sophistication of the new enthronement prayer Sta et retine, implying the role of bishops as mediators of the royal office, complemented the episcopal petition and royal promise borrowed from Erdmann. ${ }^{212}$ Clearly of interest were the references to kingship over two peoples and to paternal inheritance in Omnipotens aeterne deus, the latter reinforced in Sta et retine. ${ }^{213}$ Use of the Leiden Ordo in

represented in the Second Ordo, it is possible that the compiler had access to Hincmar's blessing and anointing prayer only, rather than the Ordo in its entirety.

208 Nelson, 'Early Medieval Rites of Queen-Making’, pp. 301-2, n. 2; Jackson, Ordines, pp. 73-5.

209 Cf. Bouman, Sacring and Crowning, pp. 129-30 and 133.

210 In an unpublished paper reported by Nelson, 'The Second English Ordo', p. 361, n. 4; idem, 'The First Use of the Second Anglo-Saxon Ordo', p. 124, n. 31. Cf. Bouman, Sacring and Crowning, pp. 157-8.

211 An overiew of the tradition formulas is available in the Appendix: see below, pp. 00-00/103-4. Two prayers are assigned in this way for each item of regalia, with the exception of the rod (uirga); the pattern is not present in Erdmann, Leiden or Seven Forms, although it could have been inspired by the treatment of the ring and crown in Erdmann, both of which have two prayers. The 'Oratio post gladium' in the Second Ordo borrowed from the preface of the Mass in the First Ordo; the 'Oratio post coronam' was largely modelled on Deus perpetuitatis auctor, the prayer after enthronement in the First Ordo, while also drawing on Hincmar's anointing formula of 869 . The use of the First Ordo here strongly implies a compiler with direct access to Erdmann, supplying a second prayer where necessary from existing English material; and, as indicated by the 'Oratio post coronam', with direct access to Hincmar's anointing formula of 869. Cf. Nelson, ' The Second English Ordo', p. 361, n. 4.

212 The Ordo of Seven Forms has long been regarded as a rich repository of political ideas: see Nelson, 'Ritual and Reality', pp. 334-5 citing Erdmann, Forschungen zur politischen Ideenwelt, pp. 56-9; E. Kantorowicz, The King's Two Bodies: a Study in Mediaeval Ruler Theology (Princeton, NJ, 1957), p. 88; Bouman, Sacring and Crowning, pp. 136-8; W. Ullmann, Principles of Government and Politics in the Middle Ages, 4th ed. (1978), pp. 130-1 and 142-3; cf. idem, The Carolingian Renaissance, pp. 107-9.

213 The slight adjustment to the Second Ordo text of Sta et retine, whereby paterna successione ('by paternal succesion') was replaced with paterna suggestione ('by paternal instigation'), might possibly be taken to 
the Second Ordo indicates that the Leiden Ordo had been in existence by 925 at the latest, since its references to two peoples were adapted for the 'Angles' and 'Saxons'. Given this early dating, one should therefore regard Leiden as the probable nucleus or core from which the Ordo of Seven Forms subsequently developed.

\section{CONTEXTUALIZING THE LEIDEN ORDO}

The terminus ante quem provided by the Second Ordo raises the possibility of situating the Leiden Ordo more closely. The problems involved in relating a surviving ordo to a specific ritual of anointing have been acknowledged. ${ }^{214}$ There are, nevertheless, good grounds for thinking that the Leiden Ordo had been drafted for a specific context. Firstly, Leiden amounted to a partial departure from the West Frankish tradition represented by Hincmar's ordines and Erdmann. ${ }^{215}$ Secondly, Leiden placed emphasis on the idea of rule over the Franks and the Aquitanians as two peoples. ${ }^{216}$ The idea appears to have been distinctive within early medieval ordines: it should be noted that Leiden is distinct from the later French sequence of ordines, descending from the 'SMN' recension of the Second Ordo, which provided for rule over 'Franks, Burgundians and Aquitanians'.217 Thirdly, in Omnipotens aeterne deus and Sta et retine, Leiden represented the king as a son succeeding his father, with his father having died: the paternum solium ('paternal throne') formed a thematic link between the anointing prayer and the reference to 'paterna successio' in the prayer of enthronement. ${ }^{218}$ Fourthly, there might be significance in the lack of a queen's ordo, although it would be hard to see this feature as diagnostic. ${ }^{219}$

The question is whether these criteria generate any candidates for a specific king. Lanoè himself suggested that Leiden had been devised for the anointing of Charles the Bald at Orléans in 848 , but the idea raises a number of difficulties. ${ }^{220}$ In particular, the Leiden anointing prayers represent a development upon the Erdmann anointing prayer: since the

\footnotetext{
imply specific initiative on the father's part, but seems more likely to have arisen as a form of elegant variation to the clause, clarifying that the ideas of paternity and hereditary right were mutually reinforcing. 'Sta et retine ammodo [statum] quem hucusque paterna suggestione tenuisti hereditario iure tibi delegatum' ('Stand and hold fast from henceforth the position, which hitherto you have held by paternal instigation, having been assigned to you by hereditary right'): Sacramentary of Ratoldus, ed. Orchard, p. 54. (the reading 'statum' is well attested in 'SMN' manuscripts and the B-version). For the Leiden text, see above, p. 00/34, n. 205.

214 See above, p. 00/7.

215 Lanoé, 'L'ordo de couronnement', pp. 46-7 and 49-50.

216 Ibid., p. 52.

217 E. A. R. Brown, 'Franks, Burgundians, and Aquitainians' and the Royal Coronation Ceremony in France, Trans. of the Amer. Philosophical Soc. 82, pt 7 (Philadelphia, PA, 1992) 15-53 and 89-97; Ordines, ed. Jackson, pp. 177-200 (MS C).

218 Lanoé, 'L'ordo de couronnement', pp. 61-2 and 64, cf .p. 52.

219 Ibid., pp. 50-1.

220 Ibid., pp. 51-6.
} 
Erdmann prayer postdates 877, in view of its relationship to the anointing prayer for Louis the Stammerer, the Leiden Ordo must also be later than 877.221 One therefore seeks a ruler who might credibly have been anointed king of the Franks and Aquitanians in the period c. $880 \mathrm{x}$ 925. The enquiry relates to the complex world of West Frankish politics after the death of Charles the Bald. The Carolingian line continued, via Louis the Stammerer and his sons, but the period was also characterized by the repeated deaths of kings, and by factional politics complicated by the intervention of viking armies. ${ }^{222}$ The line of Robert the Strong was a major beneficiary, the key turning-point being the raising of Robert's son, Odo, as king of West Francia in 888; Odo himself was anointed as king by Walter of Sens on 29 February 888. 223 In Aquitaine, the period saw increasingly autonomous action on the part of regional magnates, as successive kings struggled to maintain the integrity of the West Frankish kingdom. 224

Technically, several candidates might be considered for the first use of the Leiden Ordo. Louis III and Carloman were two kings who succeeded their dead father, Louis the Stammerer; the pair were jointly anointed and crowned at Ferrières by Ansegis of Sens in September $879 .{ }^{225}$ Yet it is clear that the 879 ritual included an episcopal petition and royal promise closely related to the preliminaries used for Louis the Stammerer in 877.226 Either Hincmar's Ordo for 877 or, given Ansegis's role, Erdmann seem the more likely possibilities. Another candidate, briefly floated by Lanoè, is the Burgundian Radulf, anointed by Walter of Sens at St-Médard, Soissons, on 13 July 923.227 Radulf's authority was recognized in Aquitaine in the years following his accession, and he bears the title Francorum et Aquitanorum atque Burgundionum rex in a charter dated 933, which has a good claim to authenticity. ${ }^{228}$ Radulf did not succeed his father, however, but became the son-in-law of his predecessor, Robert, on his marriage to Robert's daughter, Emma, later in 923.229 Nor had Robert succeeded filially; his claim in 922 derived from his status as Odo's brother.

221 Nelson, 'Early Medieval Rites of Queen-Making', p. 311, n. 54; Bouman, Sacring and Crowning, pp. 11417.

222 J. L. Nelson, 'The Frankish Kingdoms, 814-898: the West', The New Cambridge Medieval History, II: c.700-c.900, ed. R. McKitterick (Cambridge, 1995), 110-41, at 136-41; idem, Charles the Bald (Harlow, 1992), pp. 254-64.

223 Bautier, 'Sacres et couronnements', pp. 47-8; Ordines, ed. Jackson, pp. 133-8.

224 J. Dunbabin, France in the Making 843-1180, 2nd ed. (Oxford, 2000), pp. 58-60; L. Auzias, L'Aquitaine carolingienne (778-987) (Toulouse, 1937), pp. 389-448.

225 Bautier, 'Sacres et couronnements', pp. 45-6.

226 Ordines, ed. Jackson, pp. 130-2 (promissio of Carloman in 882, referring to his anointing in 879), cf. 26.

227 Bautier, 'Sacres et couronnements', pp. 49-50.

228 Recueil des actes de Robert Ier et de Raoul, rois de France (922-936), ed. R.-H. Bautier and J. Dufour (Paris, 1978), p. 95, with pp. 93-4. Cf. Lanoé, 'L'ordo de couronnement', p. 52. M. Zimmermann, 'West Francia: the Southern Principalities', New Cambridge Medieval History III, ed. Reuter, 420-55, at 429; Auzias, L'Aquitaine carolingienne, pp. 455-9 and 468-74.

229 J. Dunbabin, 'West Francia: the Kingdom', New Cambridge Medieval History III, ed. Reuter, 372-97, at $379-82$. 
Moreover, since Erdmann appears to represent Sens usage in the period after 878, there are good grounds for associating Erdmann with the anointings of 922 and $923 .{ }^{230}$ This leaves a single candidate for the use of Leiden in the only legitimate male representative of the Carolingian dynasty, Karolus Simplex, Charles 'the Simple', more properly translated as 'the Straightforward'. The young, third son of Louis the Stammerer, born in 879, Charles was raised to the West Frankish kingship in controversial circumstances in 893, and consecrated at Rheims on 28 January, the anniversary of Charlemagne's death. ${ }^{231}$ Then aged around 14, Charles was effectively being used as a claimant by the archbishop of Rheims, Fulk (882900). As Hincmar's successor, Fulk was a major player in West Frankish politics; Fulk's support for Charles's candidature provided a means of deposing the Robertine king, Odo, whose rule Fulk had consistently opposed. ${ }^{232}$ Fulk's actions in 893 resurrected the faction that had opposed Odo's kingship; Fulk himself officiated at Charles's anointing. ${ }^{233}$

Significantly, Charles's candidacy for kingship came directly from his paternity, since he was presented as the lawful successor of his father. The Annals of St-Vaast represented Charles as having been 'consecrated on the paternal throne' (in paterno solio benedictum). ${ }^{234}$ One may compare the Leiden Ordo: not only did the rite envisage a king succeeding his dead father, but in so doing it made connections with enthronement. Omnipotens aeterne deus expressed the hope that the king 'might deserve by your mercy to proceed fittingly to the paternal throne', while the enthronement prayer Sta et retine opened by appealing to 'the place which so far you have held through paternal succession, assigned to you by hereditary right'. 235 The prayer emphasized the responsibilities arising from the king's position 'on the throne of the kingdom' (in hoc regni solio). ${ }^{236}$ There was also a specific Aquitainian context for Charles the Straightforward's election. Fulk's plot against the ruling king, Odo, had taken place while Odo had been away from the kingdom's heartlands, over-wintering in Aquitaine. According to the Annals of St-Vaast, Odo had been persuaded to go to Aquitaine by the leading magnates of the kingdom, in the hope of drawing the attentions of the vikings to another region; but one may presume that other motives had been in play. ${ }^{237}$ Even prior to

\footnotetext{
230 Nelson, 'Early Medieval Rites of Queen-Making', pp. 310-11. See above, pp. 00-00/23-5.

231 Bautier, 'Sacres et couronnements', p. 49. For the date, see G. Schneider, Erzbischof Fulco von Reims (883900) und das Frankenreich, Münchener Beiträge zur Mediävistik und Renassance-Forschung 14 (Munich, 1973), 113, n. 4.

232 Nelson, 'The Frankish Kingdoms, 814-898: the West', pp. 138-40; Schneider, Erzbischof Fulco, pp. 113-18, cf. 41-66, 87-8 and 93-6; G. Koziol, The Politics of Memory and Identity in Carlingian Royal Diplomas: the West Frankish Kingdom (840-987) (Turnhout, 2012), pp. 470-9.

233 Schneider, Erzbischof Fulco, p. 113, n. 5.

234 Annals of St-Vaast s.a. 893 (Annales Vedastini, ed. B. von Simson, MGH Scriptores Rerum Germanicarum in usum scholarum separatim editi 12 (Hanover, 1909), 73).

235 'Ad paternum decenter solium tua miseratione conscendere mereatur': Lanoé, 'L'ordo de couronnement', pp. 61-2. 'Locum quem hucusque paterna successione tenuisti hereditario iure tibi delegatum': ibid., p. 64.

236 Ibid., p. 64.

237 Annals of St-Vaast s.a. 892 (ed. Simson, pp. 72-3); Nelson, 'The Frankish Kingdoms, 814-898: the West', p. 140.
} 
893, interests had been cultivated in Aquitaine on Charles's behalf: in 888, Ramnulf, count of Poitiers, had acted as guardian for Charles in Aquitaine. ${ }^{238}$ It is clear that Charles initially received some support in Aquitaine, from Richard of Burgundy, William of Aquitaine and Adhemar of Poitou, and that it took a few months for Odo to rally support there, allying with his former enemies in the region, including William of Aquitaine. ${ }^{239}$ In the event, Odo managed to rebuild his position in West Francia, and Charles was driven temporarily from the kingdom in 894.240 Charles continued to pose a threat to Odo, but after a few years came to be recognized as Odo's successor, duly succeeding to the West Frankish throne in 898.241 Interestingly, there is no indication of an anointing for Charles in 898; the nature of Odo's agreement with Charles might offer support for Robert-Henri Bautier's suggestion, that the ritual in 893 made a subsequent anointing unnecessary. ${ }^{242}$

There was an intriguing window, therefore, in early 893, when it would have made sense for Charles to have claimed rule of both Francia and Aquitaine. The circumstances present some further parallels with the scenario envisaged in the Leiden Ordo. The language used by the Annals of St-Vaast to describe Charles's consecration 'in paterno solio' was unusual; a similar formulation reappeared for 898, with the Franks restoring Charles 'in sede paterna'. ${ }^{243}$ Emphasis on the throne may have been convenient in expressing the apparent inexorability of a hereditary claim, with the throne descending to its rightful possessor. Sta et retine made a similar point by representing the throne as a place held by 'paternal succession' and 'hereditary right'. 244 The appeal of the prayer was that, already holding his place by lawful descent, the king might recognize the special status of the clergy, and thereby be strengthened 'on the throne of the kingdom' (in hoc regni solio), as mediator between the clergy and the people. ${ }^{245}$ This contrasts with the Erdmann Ordo, which makes no reference to the idea of a hereditary claim; following Hincmarian principles, the king's promise to the bishops forms the basis for his anointing. ${ }^{246}$ It is an interesting question how far perceptions may have been affected by the use of such a ritual for a non-Carolingian; both the petition and

238 Annals of St-Vaast s.a. 889 (ed. Simson, p. 67); Nelson, 'The Frankish Kingdoms, 814-898: the West', p. 139. Cf. Auzias, L'Aquitaine carolingienne, pp. 435-40.

239 Annals of St-Vaast s.a. 893 (ed. Simson, pp. 73-4); Auzias, L'Aquitaine carolingienne, pp. 446-8; Schneider, Erzbischof Fulco, p. 120. The claim, in a late source, of a division of the kingdom between Odo and Charles, in which Charles conditionally ceded Aquitaine to Odo, probably represents a garbled version of the events of 897: Chronica Albrici s.a. 893 (ed. P. Scheffer-Boichorst, MGH SS 23 (Hanover, 1874), 748). Cf. Schneider, Erzbischof Fulco, pp. 110-11, n. 150, and p. 121, n. 35.

240 Annals of St-Vaast s.a. 893 and 894 (ed. Simson, p. 74).

241 Annals of St-Vaast s.a. 897 and 898 (ed. Simson, pp. 78-9).

242 Bautier, 'Sacres et couronnements', p. 49.

243 Annals of St-Vaast s.a. 898 (ed. Simson, p. 79); cf. also Schneider, Erzbischof Fulco, p. 113, n. 5. For other contemporaneous language, see J. L. Nelson, 'Hincmar of Reims on King-Making: the Evidence of the Annals of St. Bertin, 861-82', in her Rulers and Ruling Families, no. XVII, pp. 16-32.

244 Lanoé, 'L'ordo de couronnement', p. 64.

245 For these elements of the prayer, see above, pp. 00/34, 00/37 and 00/39.

246 Erdmann Ordo 3 (Ordines, ed. Jackson, p. 147). 
promise for Odo in 888 appear to have been especially extensive. ${ }^{247}$ It is also unclear whether the Leiden Ordo would have incorporated a royal promise when the ritual was performed; the precedents of 877 and 879 might suggest so, though one must also remember Charles's young age. ${ }^{248}$ Sta et retine described a role for ecclesiastics potentially aligned with the mechanism of an episcopal petition, yet began by recognizing the king's hereditary claim.

It will be recalled that the anointing prayer in Leiden has the unique reading expressing the hope that the king 'should not abandon the kingdom of the Franks' (ut francorum regnum non deserat). ${ }^{249}$ This might seem an odd fear to express, and it was not preserved in any of the related ordines; the compiler of the Second Ordo softened the clause by adding reference to the royal throne. Yet the events of 893 present circumstances in which such a hope would have been meaningful: Odo had in the winter of 892-3 left Francia for Aquitaine, whereas Charles's rule was in its infancy. One might detect in the prayer's words pointed justification of the new regime. Charles was also unmarried, a feature at the very least compatible with the lack of a queen's ordo in Leiden.

If the above arguments are accepted, the Leiden Ordo would be closely associated with Fulk as archbishop. Significantly, therefore, a case can be made for detecting elements of Fulk's style. The letter sent by Fulk to King Alfred in the mid 880 s provides a convenient source for comparison. ${ }^{250}$ Caution is needed given the distinctive register of liturgical language, regularly relying on scriptural and other formulations. Despite these differences, one may observe parallels with phrases favoured by Fulk in his letter to Alfred: 'tramitem iustitiae' bears comparison with Fulk's 'tramitemque vivendi'; 'condigno amore' with 'condigno honore' ; the king's 'terror' with Fulk's 'potius amore ... quam terrore'; and there are parallel references to the 'temporale regnum'. ${ }^{251}$ Leiden also bears comparison with

247 Ordines, ed. Jackson, pp. 137-8. For Odo's promise, see O. Guillot, 'Les étapes de l'accession d'Eudes au pouvoir royal', Media in Francia...': Recueil de mélanges offert à Karl Ferdinand Werner (Maulévrier, 1989), pp. 199-223, at 211-12.

248 The lack of a promise in Leiden was noted by Lanoé, 'L'ordo de couronnement', pp. 49-50. For Charles's young age, see Schneider, Erzbischof Fulco, pp. 113-14 and 118. Fulk's position, as reported in his letter to Arnulf in autumn 893, was that Charles had been a 'young boy' (parvulus) in 888 , but had subsequently reached 'the age when he knew how to give assent to those offering wholesome counsel': Flodoard, Historia Remensis ecclesiae IV.5 (ed. M. Stratman, MGH SS 36 (Hanover, 1998), 380-1). The Capetian Philip I, anointed in 1059 when aged seven, is recorded as having subscribed to a professio despite his age: Memorandum of Philip I (1059) 2-3 (Ordines, ed. Jackson, pp. 227-8). Cf. the instances of Lothar, anointed at the age of thirteen in 954, and the future Louis V, anointed at the age of thirteen in 979; the form of procedure in each case is uncertain. Bautier, 'Sacres et couronnements', pp. 51 and 53.

249 Lanoé, 'L'ordo de couronnement', p. 61. See above, pp. 00-00/33-4.

250 Councils \& Synods with other Documents Relating to the English Church, I: A.D. 871-1204, ed. D. Whitelock, M. Brett and C. N. L. Brooke, 2 vols. (Oxford, 1981), pt I: 871-1066, hereafter Councils 8711066, 7-12 (no. 4); Keynes and Lapidge, Alfred, pp. 182-6. See J. L. Nelson, '...sicut olim gens Francorum...nunc gens Anglorum': Fulk's Letter to Alfred Revisited', in her Rulers and Ruling Families, no. V, pp. 135-44; Pratt, Political Thought, pp. 51-2, 57-8 and 211.

${ }^{251}$ Lanoé, 'L'ordo de couronnement', pp. 61 and 62; also 'deinceps' (p. 61). Councils 871-1066, pp. 7, 9, 11 and 12. Cf. also 'saltem partem aliquam honori suo condignam': Fulk's letter to Pope Formosus (summer 895), in Flodoard, Historia Remensis ecclesiae IV.3 (ed. Stratman, p. 376). 
Fulk's letter in tone and content on the king's obligations towards the church. Both Sta et retine and the crown formula place strident emphasis on the elevated position of bishops, the latter prayer highlighting the king's share in the episcopal ministerium and connecting this with elaborate responsibilities for the defence of the church. ${ }^{252}$ There are parallels with the hectoring tone of Fulk's letter, reviewing Alfred's responsibilities towards the ecclesiastical order, criticizing the laxity of English ecclesiastical discipline and thereby explaining the king's need for superior expertise from Rheims. ${ }^{253}$ The concept of ius haereditarium also had a role in Fulk's discourse, featuring prominently in the Vision of Charles the Fat, probably written in 890 to defend the royal claims of Louis of Provence, Charles the Fat's cousin and adopted son. ${ }^{254}$ Fulk's case for Charles the Straightforward inevitably hinged on his descent; in a letter to Pope Formosus in 895 he sought the assistance of Lambert as emperor that Charles 'might proceed to the kingdom due to him by hereditary right'. ${ }^{255}$

If the Leiden Ordo had indeed been used for Charles in 893, this would help to make sense of later patterns of anointing. Nelson has advanced an attractive case for associating the full Ordo of Seven Forms with the anointing of Louis IV 'd'Outremer' in 936 and his queen, Gerberga, in 939, both by Artold, archbishop of Rheims. ${ }^{256}$ Use for Gerberga, sister of Otto I, might help to explain the incorporation of the queen's ordo from Seven Forms into the full German Ordo, as represented in the Romano-Germanic Pontifical. ${ }^{257}$ Since, as shown by the Second Ordo, the Leiden Ordo had been in existence by 925, one must envisage a further stage in which Leiden lost its references to Franks and Aquitanians, and gained formulas for the ring and sword, together with a queen's ordo, to form the Ordo of Seven Forms. As argued above, there are grounds for suspecting that Erdmann had been used for the anointings of Robert in 922 and Radulf in 923, both performed by Walter of Sens. ${ }^{258}$ If so, this would add to the rationale for the probable development of the Ordo of Seven Forms, as a rite associated with Rheims, since it would have amounted to a signficant departure from recent practice using, in the Leiden Ordo, a rite which had been specially written at Rheims for Louis's father.

\footnotetext{
252 Lanoé, 'L'ordo de couronnement', pp. 62-4.

253 For Fulk's tone, see Nelson, “'A King Across the Sea”: Alfred in Continental Perspective', in her Rulers and Ruling Families, no. I, pp. 45-68, at 45-6 and 61-2; idem, 'Fulk's Letter to Alfred Revisted', pp. 139-43.

254 Visio Karoli III = Hariulf, Chronicon Centulense III.20-III.21 (Hariulf. Chronique de l'abbaye de SaintRiquier (Ve siècle-1104), ed. F. Lot (Paris, 1894), pp. 144-8, at p. 148). Schneider, Erzbischof Fulco, p. 111, cf. pp. 69-72; MacLean, Kingship and Politics, p. 166.

255 Fulk's letter to Pope Formosus (summer 895), in Flodoard, Historia Remensis ecclesiae IV.3 (ed. Stratman, p. 376). Cf. the famous denigration of Odo, 'ab stirpe regia [...] alienus' ('alien to the royal stock'), and defence of Charles's claim, in Fulk's letter to Arnulf (autumn 893), in ibid. IV.5 (ed. Stratman, pp. 380-3).

256 Nelson, 'Early Medieval Rites of Queen-Making', pp. 311-12. See also B. Schneidmüller, Karolingische Tradition und frühes französisches Königtum. Untersuchungen zur Herrschaftslegitimation der westfränkisch-französischen Monarchie im 10. Jahrhundert (Wiesbaden, 1979), pp. 149-51.

257 For the full German Ordo, see above, p. 00/25, n. 169.

258 See above, pp. 00-00/23-5 and 00-00/38-9.
} 
If the above identification is accepted, one would need to regard the Leiden Ordo as a new rite, drawn up by Fulk of Rheims in January 893, in order to bolster Charles's rule. The collection of formulas was distinctive, emphasizing the unity of rule over two peoples and the king's succession to the paternal throne; the rite probably had some attractions when compared with the recent tradition of anointings conducted by the archbishops of Sens. The finding has significant implications for post-888 Frankish politics, where Stuart Airlie and Simon MacLean have viewed political change in terms of a shortage of legitimate members of the Carolingian line, a development which brought dynastic legitimacy to the forefront of political discourse. ${ }^{259}$ Such legitimation has been seen as concerning Carolingian descent; Airlie has explored a role for practices of liturgical commemoration. ${ }^{260}$ In the Leiden Ordo, one may observe a further discursive and performative manifestation of political change, namely, the foregrounding of 'hereditary right' as part of the rite of anointing. The hypothesis, also suggested by Shane Bobrycki, that anointing practices may have been centrally implicated in the 'crisis of authority' of the late ninth century has a number of attractions. ${ }^{261}$ For the 893 anointing, it allows one to appreciate some of the ingenuity of Fulk's stage-management, harnessing Hincmar's ritual machinery of episcopal mediation to the recognition of Charles's irrefutable right to rule. After 898, Charles would represent his kingship as having begun on the day of his anointing in 893, adding a reference to heredity in the dating formula of diplomas after the acquisition of Lotharingia in 911.262 One of his late diplomas appealed, in terms reminiscent of Sta et retine, to the role for the sacerdotal order in sustaining the means 'by which the royal dignity might long continue to sit on the throne of the kingdom under the rod of equity (in solio regni sub aequitatis virga)' ${ }^{263}$

The finding also has wide-ranging implications for the understanding of the Second Ordo. Most immediately, it provides a terminus post quem of January 893 for the compilation of the Second Ordo, but the effects are broader, since the politics of Charles's anointing

259 S. Airlie, 'The Nearly Men: Boso of Vienne and Arnulf of Bavaria' and "'Sad Stories of the Death of Kings": Narrative Patterns and Structures of Authority in Regino of Prüm's Chronicle', in his Power and its Problems in Carolingian Europe (Farnham, 2012), no. XI, pp. 1-19, and no. XII, pp. 105-31; S. MacLean, 'The Carolingian Response to the Revolt of Boso, 879-887', EME 10 (2001), 21-48, at 44-8; idem, 'CrossChannel Marriage and Royal Succession in the Age of Charles the Simple and Athelstan (c. 916-936)', Med. Worlds 2 (2015), 26-44, esp. 39-40. See also Schneidmüller, Karolingische Tradition, pp. 9-13, 80-92 and 120-7.

260 S. Airlie, 'Les élites en 888 et après, ou comment pense-t-on la crise Carolingienne?', Les élites au haut Moyen Âge: crises et renouvellements, ed. F. Bougard, L. Feller and R. Le Jan (Turnhout, 2006), pp. 425-37, esp. 429-37. See also Schneidmüller, Karolingische Tradition, pp. 101-5, on the palace chapel of Compiègne.

261 Bobrycki, 'The Royal Consecration Ordines', pp. 136-7.

262 Koziol, The Politics of Memory, pp. 481-4; Schneidmüller, Karolingische Tradition, pp. 132-8. For the liturgical commemoration of Charles's anointing date, see S. MacLean. 'Making a Difference in TenthCentury Politics: King Athelstan's Sisters and Frankish Queenship', Frankland: the Franks and the World of the Early Middle Ages. Essays in honour of Dame Jinty Nelson, ed. P. Fouracre and D. Ganz (Manchester, 2008), pp. 167-90, at p. 186.

263 Recueil des actes de Charles III le Simple, roi de France, 893-923, ed. F. Lot and P. Lauer, 2 vols. (Paris, 1949-50), p. 253, cited by Koziol, The Politics of Memory, p. 489, cf. pp. 488-91 and 494, for the wider use of Gelasian language. 
involved a number of members of the West Frankish elite with whom King Alfred is known, or suspected, to have had favourable relations. Much hinges on the role of Grimbald, the monk and priest of St-Bertin who had been recruited into Alfred's service in the mid $880 \mathrm{~s}$, and on the role of Fulk himself, who had overseen Grimbald's recruitment. The existence of a royal rite, subsequently used in the Second Ordo, and strongly associated with Fulk, forces one to think further about these cross-Channel relations.

\section{THE LEIDEN ORDO AND CROSS-CHANNEL CONTACTS IN THE LATE NINTH CENTURY}

The identification of the Leiden Ordo as a source for the Second Ordo, and the case which has been made for connecting Leiden with the anointing of Charles the Straightforward in January 893, have implications for the understanding of cross-Channel relations in the latter part of Alfred's reign. It will now be argued, on the basis of several features of the evidence and context, that the anointing of Charles was an event of considerable significance from an Alfredian perspective, and that Alfred's connections with the see of Rheims provide an attractive probable context for the importing of the Leiden Ordo into England. These considerations strengthen the case for an Alfredian dating for the Second Ordo, in the mid to late 890s. This is a period in which Alfred's dealings with important members of the West Frankish elite can be partially reconstructed. As has long been recognized, favourable relations appear to have prevailed between the West Saxon dynasty and that of Charlemagne, extending back to the career of Ecgberht (802-829). ${ }^{264}$ In the course of the ninth century the viking attacks may have encouraged the West Saxon kingdom into closer relations with West Francia and the region of the modern-day Low Countries, which was similarly prone to viking activity. ${ }^{265}$ The case for suspecting an Alfredian context for the importing of the Leiden Ordo rests on several aspects of Alfredian rule, comprising diplomatic connections with northern Francia, historical writing connected with Alfred's court, and the role of Grimbald.

\section{King Alfred's contacts and allies in northern Francia}

\footnotetext{
264 Wallace-Hadrill, 'Charlemagne and England', pp. 162-3; Story, Carolingian Connections, pp. 213-55.

265 Wallace-Hadrill, 'The Franks and the English in the Ninth Century: Some Common Historical Interests', in his Early Medieval History, pp. 201-16, at 209; Stafford, 'Charles the Bald, Judith and England', pp. 142-4 and 152; J. L. Nelson, 'The Franks and the English in the Ninth Century Reconsidered', in her Rulers and Ruling Families, no. VI, pp. 141-58, at 141-8; Story, Carolingian Connections, pp. 224-43. P. Grierson, 'The Relations between England and Flanders before the Norman Conquest', TRHS 4th ser. 23 (1941), 71-112, at 76, 83-7 and 106; J. L. Nelson, 'Alfred's Carolingian Contemporaries', Alfred the Great: Papers from the Eleventh-Centenary Conferences, ed. T. Reuter (Aldershot, 2003), pp. 293-310, at 302-3; A. Scharer, 'King Alfred and Late Carolingian Europe', Changing Perspectives on England and the Continent in the Early Middle Ages (Farnham, 2014), no. VII, pp. 1-24, at 14-15, 20-2 and 24.
} 
One angle of approach concerns King Alfred's Continental contacts in the late ninth century. These must be seen in the context of longer-term relations between Wessex and the Carolingian dynasty, epitomized by King Æthelwulf's marriage to Judith in 856 . In the 880 s and 890s one finds fuller evidence for diplomatic activity focused on northern Francia, probably prompted by a number of stimuli: the vikings as a common enemy appear to have encouraged cross-Channel alliances, while West Saxon horizons were also broadened by Alfred's recruitment of scholars and his pious interests in relations with Rome. ${ }^{266}$ The strong association between Fulk, archbishop of Rheims, and the Leiden Ordo gains in significance given Fulk's attested contact with King Alfred and the English church. Alfred's dealings with Fulk need to be seen in the context of the archbishop's prominent role in West Frankish politics, which began in the reign of Charles the Bald, under whom Fulk had served as palace clerk, acquiring the abbacy of St-Bertin (877-83). ${ }^{267}$ By 888, after the deposition of Charles the Fat, Fulk as archbishop stood at the head of the faction opposed to the rule of Odo, inviting Wido, duke of Spoleto (and Fulk's kinsman), from Italy to rule West Francia. ${ }^{268}$

In approaching Fulk, in around 886, about the recruitment of Grimbald from StBertin, King Alfred was drawn into favourable relations with a leading West Frankish ecclesiastic much concerned with the viking threat. The need to involve the archbishop in negotiations may have arisen from Fulk's prior acquaintance with Grimbald, represented in his letter to Alfred as Fulk's 'faithful son' and a strong candidate for future episcopal office in Francia. ${ }^{269}$ Fulk is otherwise known to have been concerned, as his predecessor Hincmar, with Rheims's claims to primacy. ${ }^{270}$ Professing himself filled 'with immense grief' at the loss of Grimbald, Fulk took every opportunity to connect Grimbald's future role in England with the special status of Rheims and, drawing on Hincmarian legal theory, the superiority of Frankish ecclesiastical practices and canonical observance. ${ }^{271}$ Fulk's correspondence with England is known to have continued into the early 890s, from letters written to Alfred and to Plegmund shortly after the latter's appointment as archbishop of Canterbury in 890; in both, Fulk again appealed to canon law against the sexual behaviour of English ecclesiastics and wider English marital practices. ${ }^{272}$ Fulk's interest in the canons and the regularity of English ecclesiastical discipline is notable given the character of the Second Ordo, with the foregrounding of royal obligations towards bishops and churches in the episcopal petition and

\footnotetext{
266 For Alfredian alms-giving to Rome, see D. Pratt, 'The Illnesses of King Alfred the Great', ASE 30 (2001), 39-90, at 69-70.

267 Nelson, 'Fulk's Letter to Alfred Revisited', pp. 137-8.

268 Nelson, 'The Frankish Kingdoms, 814-898: the West', p. 138.

269 Councils 871-1066, pp. 10-11.

270 Nelson, 'Fulk's Letter to Alfred Revisited', pp. 139-40; Schneider, Erzbischof Fulco, pp. 183-94.

271 Councils 871-1066, pp. 10-12. For the relationship to Hincmar's thought, see Pratt, Political Thought, pp. 223-7, cf. p. 25, n. 47; Wormald, Making of English Law I, 425-6. Cf. esp. J. Devisse, Hincmar Archevêque de Reims 845-882, 3 vols. (Geneva, 1975-6) II, 549-58.

272 Councils 871-1066, pp. 12-13 (nos. 5 and 6); English Historical Documents, ed. Whitelock, pp. 886-7 (nos. 224 and 225). Brooks, Canterbury, p. 153; Pratt, Political Thought, pp. 211-12.
} 
royal promise, ultimately derived from Hincmarian theory. 273 The message was reinforced by Sta et retine, borrowed from Leiden. ${ }^{274}$ The role of Grimbald in Alfred's service, and Fulk's continuing contact with Alfred and Plegmund, provides a documented conduit by which the Leiden Ordo could have reached England, the plausibility of which is strengthened by the nature of Fulk's interests.

Another dimension is the relationship between King Alfred and the counts of Flanders, regional magnates in the territory containing St-Omer and Arras. ${ }^{275}$ An important context is suggested by the subsequent career of Judith, whose brief marriage to Æthelwulf's son, Æthelbald, after his father's death in 858, ended on the death of Æthelbald in 860 . Selling up her English property, Judith retured to Charles the Bald, but subsequently eloped with Baldwin I, count of Flanders, in 862.276 Although Judith's significance in Frankish politics arose primarily from her descent, her marriage to Baldwin the following year technically created a step-relationship between her offspring and those of Æthelwulf, including Alfred. The link was presumably remembered at the time of a further marriage, probably contracted between 893 and 899, between Baldwin II (d. 918), Alfred's step-brother, and Alfred's youngest surviving daughter, Elfthryth. ${ }^{277}$ One may suspect an alliance between Alfred and Baldwin II stimulated by anti-viking warfare. As Scharer has pointed out, both Fulk and Baldwin II appear to have been involved in the construction of fortifications; Fulk presided over the re-walling of Rheims, while Baldwin II may be associated with a series of castles erected on the Flanders coast. ${ }^{278}$ Alfred and Baldwin II used some similar tactics against what was effectively a common enemy. The viking 'great army' that invaded England in the autumn of 892 had assembled at Boulogne, the main component having been based at Louvain in 891-2.279 Another contingent was led by Hastein, who would go on to renege on agreements with Alfred and Alfred's son-in-law, Ethelred, ealdorman of the Mercians, in

273 Sacramentary of Ratoldus, ed. Orchard, pp. 47-8; Erdmann Ordo 2-3 (Ordines, ed. Jackson, p. 147). Nelson, 'Kingship, Law and Liturgy', pp. 149-55.

274 Sacramentary of Ratoldus, ed. Orchard, p. 54; Lanoè, 'L'ordo de couronnement', p. 64.

275 See in general H. J. Tanner, Families, Friends and Allies: Boulogne and Politics in Northern France and England, c. $879-1160$ (Leiden, 2004), pp. 20-7 and 44-59; B. Mejins, 'The Policy on Relic Translations of Baldwin II of Flanders (879-918), Edward of Wessex 899-924), and Æthelflæd of Mercia (d. 924): a Key to Anglo-Flemish Relations?', England and the Continent, ed. Rollason et al., pp. 473-92.

276 Annals of St-Bertin s.a. 862 (ed. Grat et al., pp. 87-8; Nelson, Annals of St-Bertin, p. 97).

277 Æthelweard, Chronicon Prol. (ed. Stevenson, p. 2); Grierson, 'Relations between England and Flanders', pp. 85-7; Nelson, 'Alfred's Carolingian Contemporaries', pp. 302-3; Mejins, 'The Relic Policy’, pp. 478-9.

278 Scharer, 'King Alfred and Late Carolingian Europe', pp. 21-2. See also R. Hodges, 'Trade and Market Origins in the Ninth Century: Relations between England and the Continent', Charles the Bald: Court and Kingdom, ed. M. T. Gibson and J. L. Nelson, 2nd ed. (Aldershot, 1990), pp. 203-23, at 219-21; Mejins, 'The Relic Policy', pp. 478-9.

279 ASC 892 AEF, 893 BCD (= 892): Two Chronicles, ed. Plummer I, 84-5 (text); Anglo-Saxon Chronicle, ed. Whitelock et al., p. 54 (translation). Annals of St-Vaast s.a. 891 and 892 (ed. von Simson, pp. 70 and 72 ). Keynes and Lapidge, Alfred, pp. 283-4, n. 19. 
893. ${ }^{280}$ Hastein and his followers had been at Argoeuves, on the Somme, in 890-1, and at Amiens in 891-2.281 It is tempting to connect Baldwin II with the presence of Frisians in Alfred's service, attested for 896 in a naval force: the report suggests the value of crossChannel cooperation. ${ }^{282}$

Baldwin II also had his own complex dealings with Fulk, allying with the archbishop against Odo in 888. Baldwin had probably supported Fulk's scheme to install Wido, and is implicated by the Annals of St-Vaast in the brief attempt to offer the West Frankish throne to Arnulf of East Francia. ${ }^{283}$ From 892-3, however, Baldwin II fell into prolonged conflict with Fulk over the control of the monasteries of St-Bertin and St-Vaast; the dispute would ultimately cost Fulk his life, assassinated in 900 by one of Baldwin's men. ${ }^{284}$ Baldwin's attitude to Fulk's anointing of Charles is unclear; in 895 he is reported as having supported Charles, ultimately switching his allegiance to Odo, but it is possible that he may have initially remained neutral. ${ }^{285}$ Certainly, the anointing occurred at the key point of inflection between King Alfred's northern Frankish contacts.

A further probable ally was the near-contemporary lay abbot of St-Bertin, Rodulf, who held the lay abbacies of St-Bertin and St-Vaast from 883 to 892 . Rodulf has recently surfaced in an Alfredian context thanks to Scharer's important arguments for suspecting that Alfred and Rodulf had been in contact. ${ }^{286}$ Rodulf's power is indicated by his membership of the Frankish aristocratic family of Eberard of Friuli, the Unruochings, who had extensive landholding in Flanders and the Artois, northern Italy and Alemannia. The family had a direct relationship to the Carolingian dynasty via the marriage of Eberhard to Gisla, daughter of Louis the Pious, who was thus aunt of Charles the Bald's daughter, Judith. ${ }^{287}$ Through Judith's marriage, the Unruochings were also related to the counts of Flanders; Rodulf and Baldwin II were second cousins. ${ }^{288}$ Scharer has put forward a compelling case for suspecting friendly relations between Eberhard's family and that of Æthelwulf from the time of

280 Annals of St-Vaast s.a. 890 (ed. von Simson, pp. 68-9). For Hastein's exploits in England, see Scharer, 'King Alfred and Late Carolingian Europe', pp. 23-4; J. L. Nelson, 'England and the Continent in the Ninth Century: II, The Vikings and Others', TRHS 6th ser. 13 (2003), 1-28, at 24-5 and 27.

281 Annals of St-Vaast s.a. 890 and 891 (ed. von Simson, pp. 68 and 70). Keynes and Lapidge, Alfred, pp. 2845, n. 25.

282 ASC 896 ABF, 897 CD (= 896): Two Chronicles, ed. Plummer I, 91 (text); Anglo-Saxon Chronicle, ed. Whitelock et al., p. 58 (translation). Asser, Vita Alfredi, c. 76 (ed. Stevenson, p. 60; Keynes and Lapidge, Alfred, p. 91, cf. p. 258, n. 57).

283 Annals of St-Vaast s.a. 888 (ed. von Simson, p. 65). Nelson, 'The Frankish Kingdoms, 814-98: the West', p. 138; Scharer, 'King Alfred and Late Carolingian Europe', p. 14; Tanner, Families, Friends and Allies, p. 25.

284 Scharer, 'King Alfred and Late Carolingian Europe', pp. 15 and 20; Schneider, Erzbischof Fulco, pp. 96109 and 177-82; Tanner, Families, Friends and Allies, pp. 25-6; Koziol, The Politics of Memory, pp. 477-9.

285 Annals of St-Vaast s.a. 895 (ed. von Simson, p. 76). Cf. Tanner, Families, Friends and Allies, pp. 26 and 53-4.

286 Scharer, 'King Alfred and Late Carolingian Europe', pp. 2, 12-15 and 22-4.

287 Ibid., pp. 5-6 and 9-12.

288 Ibid., p. 14; S. Joye, 'Le rapt de Judith par Baudoin de Flandre (862): un “clinamen sociologique”?', Les élites au haut Moyen Âge, ed. Bougard et al., pp. 361-79, at 373-7. 
Ethelwulf's visit to Rome in 855-6.289 Scharer notes the close connections between Eberhard's family and the female religious house of San Salvatore, Brescia, in the Liber Vitae of which the names of Æthelwulf's entourage were recorded, also highlighting Æthelwulf's correspondence with the scholar Lupus of Ferrières, who enjoyed Eberhard's patronage. ${ }^{290}$ From Fulk's letter to Alfred, it is clear that the king had approached Fulk with Grimbald already identified as a proposed recruit. ${ }^{291}$ As Scharer has implied, Rodulf may be the 'missing link' in explaining Grimbald's recruitment, since Rodulf's grandfather had retired to St-Bertin, and his uncle had been lay abbot there. ${ }^{292}$ It seems likely that the prior link between the families of Rodulf and Alfred had prompted a direct enquiry to St-Bertin, which then had to be squared with Fulk. As abbot of St-Vaast, moreover, Rodulf led resistance against Hastein in 890-1, and he defended St-Bertin against the great army in the spring of 891.293 Rodulf was also an ally of Fulk and Baldwin in the faction of 888, participating in the offer of the throne to Arnulf. ${ }^{294}$ Rodulf's death, on 5 January 892, helped to shape the political context at the time of Charles's anointing, since it opened up the enmity between Fulk and Baldwin II over the control of St-Bertin and St-Vaast. ${ }^{295}$ In view of the known contact between Wessex and St-Bertin, one may suspect awareness from an Alfredian perspective of the consequences of Rodulf's death.

\section{Historical writing associated with King Alfred's court}

Another angle of approach is provided by the writing of history. Conveniently, the two principal works of Alfredian historical writing, the Anglo-Saxon Chronicle and Asser's Life of King Alfred, were either recently completed, or in preparation, at the time of Charles's anointing. Not only is there the prospect of gauging Alfredian attitudes towards developments in northern Francia: shared intellectual and political concerns with the Frankish world have often been considered as a possible stimulus to the writing of the Chronicle and Asser's

\footnotetext{
289 Scharer, 'King Alfred and Late Carolingian Europe', p. 9.

290 Ibid., pp. 3-12; S. Keynes, 'Anglo-Saxon Entries in the "Liber Vitae" of Brescia', Alfred the Wise: Studies in honour of Janet Bately, ed. J. Roberts and J. L. Nelson, with M. Godden (Cambridge, 1997), pp. 99-119. As Scharer notes, Lupus had at the time of his letters to England (852) recently regained the abbacy of St-Josse, Pas-de-Calais ('King Alfred and Late Carolingian Europe', p. 3).

${ }^{291}$ Scharer, 'King Alfred and Late Carolingian Europe', p. 15. Cf. the reference in Fulk's letter to Grimbald's returning to England 'cum suis electoribus, et cum nonnullis regni vestri proceribus vel optimatibus tam episcopis scilicet, presbyteris, diaconibus, quam etiam religiosis laicis' ('with those who have chosen him, and with some noblemen and magnates of your kingdom, both bishops and priests and deacons as well as religious laymen'): Councils 871-1066, p. 11. Fulk's words would be compatible with the involvement of a delegation from St-Bertin in Grimbald's selection.

${ }^{292}$ Scharer, 'King Alfred and Late Carolingian Europe', pp. 13-15.

293 Ibid., pp. 22-3.

294 Annals of St-Vaast s.a. 888 (ed. von Simson, p. 65); Scharer, 'King Alfred and Late Carolingian Europe', p. 14.

295 Ibid., pp. 15 and 20.
} 
Life. ${ }^{296}$ One should acknowledge the many uncertainties here, over the degree of relationship between the Chronicle and King Alfred's patronage, over Asser's intentions and the extent to which his biography had royal oversight or approval. Nevertheless, it is clear that all manuscripts of the Chronicle derive from copies disseminated centrally, probably in the autumn of 892, and that Asser, working in 893 , had access to an early version of the Chronicle text. ${ }^{297}$ In general, the incentives towards the compilation of the Chronicle may be presumed to have lain, firstly, in the broader politics of the 'kingdom of the Anglo-Saxons', namely, Alfred's efforts to consolidate control over his enlarged kingdom, and, secondly, in royal efforts to promote vernacular prose as a medium of education. ${ }^{298}$ Nevertheless, as Michael Wallace-Hadrill first observed, the Chronicle project seems likely to have been framed in awareness of the Frankish tradition of historical writing, while in execution the Chronicle's horizons increasingly included the Frankish world, reaching a high point in the period 880-892.299 Of central importance is the annal for 892, reporting the return of the 'great army' from Boulogne, followed by the arrival of Hastein. ${ }^{300}$ The inclusion of these reports, following the interest in the activities of the 'great army' on the Continent in the 880s, strengthens the case for regarding 892 as the final annal of the 'common stock', in which case the Chronicle's dissemination might be understood as responding to the viking threat. $^{301}$ The assembling of the 'great army' at Boulogne in 892, in the environs of Alfred's northern Frankish allies, suggests a wider context for the act of dissemination.

The Chronicle's interest in Frankish affairs included the key turning-points in the West Frankish kingdom in the 880s. The singular nature of these entries warrants further attention in the light of Alfredian diplomatic contacts and English knowledge of the Leiden Ordo. The entries begin with the deaths of Carloman (884) and Louis II (882), sons of Louis the Stammerer, moving to the accession of Charles the Fat, reported in terms comparing his territory to that of his great-grandfather, Charlemagne. ${ }^{302}$ This provides the backdrop for a

296 For relevant perspectives, see S. Keynes, 'Alfred the Great and the Kingdom of the Anglo-Saxons', A Companion to Alfred the Great, ed. N. G. Discenza and P. E. Szarmach (Leiden, 2015), pp. 13-46, at 34-9; N. Brooks, 'Why is the Anglo-Saxon Chronicle about Kings?', ASE 39 (2010), 43-70, at 5-6; J. Campbell, 'Asser's Life of Alfred', in his Anglo-Saxon State, pp. 129-51; T. M. Kalmar, 'Asser's imitatio of Einhard: Clichés, Echoes, and Allusions', EOLAS 7 (2014), 65-91.

297 Keynes and Lapidge, Alfred, pp. 277-9; J. Bately, The Anglo-Saxon Chronicle: Texts and Textual Relationships, Reading Medieval Studies Monograph 3 (Reading, 1991), 53-5 and 59-62.

298 Keynes, 'King Alfred and the Mercians', pp. 40-1; idem, 'Alfred the Great and the Kingdom of the AngloSaxons', pp. 34-5; Pratt, Political Thought, pp. 106-7 and 117.

299 Wallace-Hadrill, 'The Franks and the English', pp. 209-10; Nelson, “"A King Across the Sea"', pp. 46-7; Keynes, 'Alfred the Great and the Kingdom of the Anglo-Saxons', p. 34.

300 ASC 892 AEF, 893 BCD (= 892): Two Chronicles, ed. Plummer I, 84-5 (text); Anglo-Saxon Chronicle, ed. Whitelock et al., p. 54 (translation).

301 Keynes and Lapidge, Alfred, pp. 278-9, cf. 39-41; S. Keynes, 'A Tale of Two Kings: Alfred the Great and Fthelred the Unready', TRHS 5th ser. 36 (1986), 195-217, at 197-8; idem, 'Alfred the Great and the Kingdom of the Anglo-Saxons', pp. 34-5.

302 ASC 885 ABDEF, 886 C (= 885): Two Chronicles, ed. Plummer I, 78-80 (text); Anglo-Saxon Chronicle, ed. Whitelock et al., p. 51 (translation). 
more pointed entry on the deposition and death of Charles the Fat in the annal for 887.303 The entry recalls Regino of Prüm's famous account of the consequences of Charles's deposition, and conveys a comparable sense of decisive fragmentation, underlined by its late position in the 'common stock'. ${ }^{304}$ As Nelson has commented, the Chronicle's account reflects a view of 887-8 favourable to Fulk and lukewarm to Odo, including reference to Wido as a claimant to kingship, and emphasizing Arnulf's authority over the Frankish kingdoms after 888. ${ }^{305}$ Even after the failed attempt to install Arnulf on the West Frankish throne, the view in the Annals of St-Vaast was that Odo owed his position to Arnulf, a point emphasized by the report that Arnulf had a sent a crown for Odo's coronation at Rheims on 13 November 888. 306 The Chronicle's perspective probably reflects a broader Alfredian view of West Frankish politics, rather than merely the sources of information available, and may have arisen from the network of contacts: namely, Rodulf, whose brother Berengar of Friuli was another beneficiary in 888, and Baldwin II, as well as Fulk.

It is therefore striking that the annalist should have connected the fragmentation of Charles the Fat's territory with royal anointing. 'And pa wearp pæt rice todæled on .v. and .v. kyningas to gehalgode': the five kings comprised Arnulf in East Francia, Rudolf in Upper Burgundy, Odo in West Francia, and Berengar and Wido in northern Italy. ${ }^{307}$ It is an interesting question whether this statement had reached its received form before or after the anointing of Charles the Straightforward on 28 January 893, since this would have a bearing on the annalist's interest in the anointing of kings. If, as seems likely, the 'common stock' had been disseminated in the autumn of 892 , then one would need to read the statement as prompted by the complex events of 888 ; but one should acknowledge the possibility that the composition of the 'common stock' had continued into early 893, in which case the statement could reflect awareness of the most recent and politically charged use of anointing. At the very least, the concern expressed at the anointing of kings outside the male line indicates awareness of an issue which had valency, given the claims made by Fulk on Charles's behalf, while, from an English perspective, there were some significant contrasts with recent succession practices in Wessex. ${ }^{308}$

\footnotetext{
303 ASC 887 ABDEF, 888 C (= 887): Two Chronicles, ed. Plummer I, 80-1 (text); Anglo-Saxon Chronicle, ed. Whitelock et al., p. 52 (translation).

304 Regino of Prüm, Chronicon s.a. 888 (ed. F. Kurze, MGH Scriptores Rerum Germanicarum in usum scholarum separatim editi 50 (Hanover, 1890), 129-30). Cf. Nelson, 'Alfred's Carolingian Contemporaries', p. 301.

305 Nelson, 'Fulk's Letter to Alfred Revisted', pp. 138-9; idem, 'The Franks and the English', pp. 148-9.

306 Annals of St-Vaast s.a. 888 (ed. von Simson, p. 67).

307 'The kingdom was then divided into five, and five kings were anointed to it': The Anglo-Saxon Chronicle MS A, ed. J. M. Bately, The Anglo-Saxon Chronicle: a Collaborative Edition, ed. D. Dumville and S. Keynes 3 (Cambridge, 1986), 53 (text); Anglo-Saxon Chronicle, ed. Whitelock et al., p. 52 (translation).

308 Cf. Fulk's letter to Arnulf (autumn 893), in Flodoard, Historia Remensis ecclesiae IV.5 (ed. Stratman, pp. 380-3). Nelson, 'Alfred's Carolingian Contemporaries', pp. 301-2.
} 
The situation is clearer, however, in the case of Asser's Life. Asser represents himself as writing the Life in 893, and his handling of Welsh affairs would imply that work continued well into the summer. ${ }^{309} \mathrm{He}$ had good knowledge of recent Frankish history, adding further details to the Chronicle's entries for 885-7.310 Although Asser does not refer to Charles's anointing, its timing, in January, makes it likely that news of the event would have reached him while working on his text. Asser's treatment of the deposition of Charles the Fat is therefore striking. The Chronicle's annal becomes merely the starting-point for a more expansive account, emphasizing even further Arnulf's overall authority, now connected with his holding 'the main seat of the realm' (principalis sedes regni), with the obedience of the other four kings justified by Arnulf's superior dynastic claim: 'Ceteri quoque quatuor reges fidelitatem et oboedientiam Earnulfo, sicut dignum erat, promiserunt: nullus enim illorum quatuor regum hereditarius illius regni erat in paterna parte, nisi Earnulf solus'. 311 Having already translated the Chronicle's statement on the anointing of five kings, Asser adds a comment emphasizing Arnulf's higher authority: 'Quinque itaque reges confestim, Karolo moriente, ordinati sunt, sed imperium penes Earnulf remansit'. ${ }^{312}$ It is difficult not to regard these expansions as having been written in the knowledge both of Charles's anointing and of the subsequent conflict between Charles and Odo after Easter 893. Fulk had, in January, reactivated the faction of 888 (probably minus Baldwin II), and whereas Arnulf's authority had been important in 888, the hardening of Asser's line on Arnulf's legitimacy would make sense in the light of the hereditary claim now being advanced for Charles. The issue of Arnulf's authority remained in play in 893 , and would be called upon in the following year, when Arnulf gave support to his cousin against Odo. ${ }^{313}$

309 Crucial here are Alfred's relations with the king of Gwynedd, Anarawd, son of Rhodri Mawr, who in the mid or later 880s formed an alliance with viking forces settled in Northumbria: Asser, Vita Alfredi, c. 80 (ed. Stevenson, pp. 66-7; Keynes and Lapidge, Alfred, p. 96). Asser's statement that Anarawd 'received no benefit, only a great deal of harm' from this alliance seems likely to postdate the siege of Buttington, on the border of Powys, in 893. This engagement, a major viking defeat, provides a plausible context for Anarawd's abandoning of the Northumbrian alliance, and subsequent submission to King Alfred. See Pratt, Political Thought, pp. 108-9. Cf. D. P. Kirby, 'Asser and his Life of King Alfred', Studia Celtica 6 (1971), 12-35, at 16-17. For a different view, see T. M. Charles-Edwards, Wales and the Britons 350-1064 (Oxford, 2013), pp. 493-4, cf. 507-8.

310 Keynes and Lapidge, Alfred, pp. 55, 252-3 and 267.

311 'The other four kings also promised fealty and obedience to Arnulf, as was only fitting: for none of those four kings had any hereditary right to the kingdom on his father's side, only Arnulf': Asser, Vita Alfredi, c. 85 (ed. Stevenson, p. 72; Keynes and Lapidge, Alfred, p. 98). 'Pæt wæs peah mid Earnulfes gepafunge, and hi cuædon pæt hie pæt to his honda healdan sceoldon forpæm hira nan næs on fædren healfe to geboren buton him anum' ('It was done, however, with Arnulf's consent and they said that they would hold it under him, for not one of them was born to it in the male line but him alone'). ASC 887 A: ASC MS A, ed. Bately, p. 53 (text); Anglo-Saxon Chronicle, ed. Whitelock et al., p. 52 (translation).

312 'In short, five kings were consecrated immediately upon the death of Charles, but the overall authority remained in the hands of Arnulf': Asser, Vita Alfredi, c. 85 (ed. Stevenson, p. 72; Keynes and Lapidge, Alfred, p. 98).

313 Schneider, Erzbischof Fulco, pp. 114-21 and 127-43. Fulk's letter to Arnulf (autumn 893), in Flodoard, Historia Remensis ecclesiae IV.5 (ed. Stratman, pp. 380-3). Annals of St-Vaast s.a. 894 (ed. von Simson, p. 74). 
Asser's final sentences are thus intriguing: 'Nec tamen tanta et talia regna inter se pacifice servaverunt. Nam bis pleno proelio inter se belligeravere, et illa regna persaepe devastaverunt invicem, et unusquique alterum expulit de regno'.314 As Keynes and Lapidge note, these statements might possibly be read in the manner of the Chronicle's entry as referring to Berengar and Wido specifically, and thus to the battles of Brescia (autumn 888) and Trebbia (spring 889) as the two moments of outright warfare. ${ }^{315}$ Asser's words are more general, however, implying conflict between multiple kingdoms ('tanta et talia regna'), while 'tamen' reads most naturally as qualifying Asser's earlier reference to the overall division of Charles the Fat's former territory: 'Talis ergo illius regni divisio fuit'. ${ }^{316}$ It may be that Asser was himself uncertain as to the import of the Chronicle's tu folcgefeoht ('two general engagements'), but in the light of his other changes it is tempting to read Asser's treatment of the two conflicts in a West Frankish context, as referring to the events of 888 and to the mobilizations led by Odo and Charles in the spring and summer of 893 . It would be hazardous to press the point given the general nature of Asser's statements, but the matter is of some importance, since it raises the possibility of a veiled reference by Asser to the consequences of Charles's anointing.

\section{Charles the Straightforward, Asser and the memory of Charlemagne}

Though the impact on Asser's narrative might be debated, the strong suspicion that he wrote in awareness of Charles's anointing is supported by considerations of chronology. The likelihood that Asser had knowledge of recent Frankish developments has implications for the overall interpretation of the Life. Identifying the events of St Martin's Day (11 November) 887, when Alfred took his first steps in translating Latin into English, as the 'thematic fulcrum of the Life', Patrick Wormald noted Asser's awareness of the chronological correlation between this turning-point and the death-throes of the Carolingian empire. ${ }^{317}$ The point is important because it concerns Asser's intentions as a biographer, which related to his engagement with Einhard's Life of Charlemagne. That 887 had deeper significance for Asser is suggested by the fact that the annal for that year is the last Chronicle entry to be included in

\footnotetext{
314 'They did not, however, preserve those extensive kingdoms thus defined peacefully among themselves: on two occasions they waged all-out war against each other, and very frequently took turns at laying waste the other kingdoms, and each of them drove the other from his realm': Asser, Vita Alfredi, c. 85 (ed. Stevenson, p. 72; Keynes and Lapidge, Alfred, p. 98).

315 'And pæt healdun mid micelre unsibbe and tu folcgefeoht gefuhton and pæt lond oft and gelome forhergodon, and æghwæper operne oftrædlice ut dræfde' ('and they held it with much discord and fought two general engagements, and ravaged the land again and again, and each repeatedly drove out the other'). ASC 887 A: ASC MS A, ed. Bately, p. 53 (text); Anglo-Saxon Chronicle, ed. Whitelock et al., p. 52 (translation). Keynes and Lapidge, Alfred, p. 206, n. 203 and n. 205.

316 'The division of the empire, then, was as follows': Asser, Vita Alfredi, c. 85 (ed. Stevenson, p. 72; Keynes and Lapidge, Alfred, p. 98).

317 P. Wormald, 'Living with King Alfred', HSJ 15 (2004), 1-39, at 19 and 39, cf. 31. Asser, Vita Alfredi, cc. 87-9 (ed. Stevenson, pp. 73-5; Keynes and Lapidge, Alfred, pp. 99-100).
} 
the Life. 318 The consequences of the death and deposition of Charles the Fat are thus juxtaposed in pointed fashion with the entry for 886, reporting Alfred's 'restoration' of London and receiving of submission from all Angles and Saxons. ${ }^{319}$ These entries occur at a pivotal point in Asser's narrative, sandwiched between the lengthy account of the king's illnesses and summoning of scholars to the royal household (cc. 73-81), and the final section, recounting the king's learned and pious activities: his first steps in translation, his monastic foundations, the division of revenues, his candle-lantern and concern for justice (cc. 87-106). It should be noted that the key day in Alfred's life, 11 November 887, was also the date widely assigned to Charles the Fat's deposition. ${ }^{320}$

As Wormald hinted, the overall framework suggests a bold response to Einhard, representing Alfred as emulating Charlemagne's learned achievements, or even surpassing them in respect of the king's personal commitment, at a time when Charlemagne's dynasty and empire appeared to have failed. The implied juxtaposition of Alfred and Charles the Fat had rhetorical potential in a wider European context. In 885-6, the monk of St Gall, Notker the Stammerer, had composed his own (unfinished) biography of Charlemagne, the Gesta Karoli, for Charles the Fat. Notker had subtly praised and exhorted Charles on sustaining his great-grandfather's empire. ${ }^{321}$ Whether Asser would have known of Notker's work is uncertain: there is no verbal correspondence, or clear indication of engagement. ${ }^{322}$ Yet Charlemagne's memory remained central to both biographers. It is accordingly of some significance that, at the time when Asser was constructing his bold treatment, he wrote in probable knowledge of the new twist in the fate of the Carolingian male line: namely, the 'new hope' represented by the young Charles the Straightforward from January 893 onwards. The development was insufficient to derail Asser's narrative, but added a complication to his efforts to view 887 as a decisive turning-point. Such considerations provide a context for Asser's close attention to the entry for 887.

Asser's testimony also has significance for later developments in Charles the Straightforward's career. When Charles regained power in West Francia in 898 he continued to have favourable relations with the West Saxon dynasty, and married one of Edward the Elder's daughters, Eadgifu, in the late 910s. ${ }^{323}$ After Charles was himself deposed in 923, his

\footnotetext{
318 Asser, Vita Alfredi, cc. 84-6 (ed. Stevenson, pp. 71-2; Keynes and Lapidge, Alfred, pp. 98-9). See Keynes, 'Alfred the Great and the Kingdom of the Anglo-Saxons', pp. 37-9.

319 Asser, Vita Alfredi, cc. 82-3 (ed. Stevenson, pp. 68-9; Keynes and Lapidge, Alfred, pp. 97-8). ASC 886 ABDEF, 887 C (= 886): Two Chronicles, ed. Plummer I, 80-1 (text); Anglo-Saxon Chronicle, ed. Whitelock et al., p. 52 (translation).

320 MacLean, Kingship and Politics, pp. 194-5.

321 Ibid., pp. 199-229.

322 The works are briefly compared by Campbell, 'Asser's Life of Alfred', pp. 136-7.

323 Æthelweard, Chronicon Prol. (ed. Stevenson, p. 2). William of Malmesbury, Gesta regum II.126, in William of Malmesbury: Gesta Regum Anglorum / The History of the English Kings, ed. R. A. B. Mynors, R. M. Thomson and M. Winterbottom, 2 vols. (Oxford, 1998-9) I, 198-200. Keynes, 'King Athelstan's Books', p. 191.
} 
infant son, Louis 'd'Outremer' was subsequently sent for safe-keeping to the household of his uncle, King Æthelstan. ${ }^{324}$ These developments have generally been seen in the context of Edward's ambitions as a dynast, and of Æthelstan's subsequent posturing as a ruler laying claim to the legacy of Charlemagne. ${ }^{325}$ MacLean has emphasized an internal West Frankish context, highlighting the weakness of Charles's political position at the time of his marriage to Eadgifu. ${ }^{326}$ The subsequent Continental marriages of Æthelstan's half-sisters, particularly that of Eadhild to Hugh the Great, duke of the Franks, in 926, may have been stimulated by the infant Louis's presence in England, and by diplomatic positioning over the West Frankish succession. ${ }^{327}$ One may add a further layer of contextualization: West Saxon support for Charles's line appears to have been consistent and had its roots in Alfred's reign, shaped by relations with Rheims and by the ideological significance of Charlemagne's legacy for Alfredian rule. Such an orientation was probably initiated or intensified by Charles's anointing.

\section{The career of Grimbald of St-Bertin in England}

A further angle of approach concerns the role of Grimbald of St-Bertin (d. 901), a matter of some importance since Grimbald has generally been identified as a likely conduit for the knowledge of West Frankish learning and ideas in Alfred's household. The understanding of Grimbald's royal service is complicated by the slightly differing emphases of Asser and Fulk. Asser regarded Grimbald as a teacher, assisting the king in his desire for divine wisdom and knowledge of the liberal arts, describing Grimbald as 'a very venerable man, an excellent chanter, extremely learned in every kind of ecclesiastical doctrine and in the Holy Scriptures, as well as being distinguished by his virtuous behaviour'.328 Fulk's letter reveals further details, indicating that Alfred had written to Fulk informing him of his efforts to restore the ecclesiastical order, and seeking Grimbald's service. ${ }^{329}$ There is no necessary implication that Grimbald had been recruited for an episcopal office: although Fulk clearly regarded Grimbald as worthy of a bishopric, the letter refers more neutrally to responsibilities of spiritual oversight, through which Grimbald might aim 'to superintend the administration of pastoral

\footnotetext{
324 Foot, Ethelstan, pp. 46-7; J. L. Nelson, 'Eadgifu (d. in or after 951)', Oxford Dictionary of National Biography (Oxford, 2004), hereafter $O D N B$, available online.

325 F. M. Stenton, Anglo-Saxon England, 3rd ed. (Oxford, 1971), pp. 344-49; S. Sharp, 'The West Saxon Tradition of Dynastic Marriage: with Special Reference to Edward the Elder', Edward the Elder, ed. Higham and Hill, pp. 79-88; V. Ortenberg, “The King from Overseas”: Why did Æthelstan Matter in Tenth-Century Continental Affairs?', England and the Continent in the Tenth Century, ed. Rollason et al., pp. 211-36. See also Foot, Athelstan, pp. 44-58, cf. 192-8.

326 MacLean, 'Cross-Channel Marriage', pp. 29-30. Cf. also idem, 'Making a Difference in Tenth-Century Politics'.

327 MacLean, 'Cross-Channel Marriage', pp. 31-40.

328 Asser, Vita Alfredi, c. 78 (ed. Stevenson, p. 63; Keynes and Lapidge, Alfred, p. 93).

329 Councils 871-1066, pp. 7-8 and 10.
} 
care'. ${ }^{330}$ In reluctantly agreeing to his recruitment, Fulk commended Grimbald's example as a pastor and teacher. ${ }^{331}$ In the event, efforts appear to have been made to elevate Grimbald: according to Winchester tradition of the late tenth century, Alfred initially installed Grimbald in a small monastery which he had had constructed in Winchester, before offering him the see of Canterbury on the death of Archbishop Æthelred (888), but Grimbald refused, instead recommending Plegmund for the office. ${ }^{332}$ As Nicholas Brooks observed, the story could account for the delay between Æthelred's death and Plegmund's election in 890, and might also help to explain why Fulk took the opportunity of writing to Alfred and Plegmund, congratulating the former on Plegmund's election. ${ }^{333}$

In Grimbald's career one is therefore dealing with a learned teacher with spiritual responsibilities who, unusually among Alfred's scholarly assistants, did not attain episcopal office. Asser's words indicate an expertise in liturgy, while Fulk attributes to Grimbald superior knowledge of ecclesiastical law. According to Asser, comparing Grimbald's contribution with that of Alfred's other Continental scholar, John the Old Saxon, 'Through their teaching the king's outlook was very considerably broadened'. 334 These points should be remembered when considering Grimbald's impact on Alfredian learning. Grimbald has been put forward as the means by which a number of northern Frankish manuscripts with a later English provenance crossed the Channel, and he had a significant impact on the literary output of Alfred's household. ${ }^{335}$ Grimbald's assistance to the king is acknowledged in the Prose Preface to the translation of the Regula pastoralis, but there are grounds for suspecting the influence of scholarly helpers in other texts attributed to Alfred's authorship. Janet Bately has advanced, and robustly defended, the broader case for regarding the royal corpus as the output of 'one mind at work (though probably never entirely on its own)', a process which was in some sense collective, involving scholarly interaction. ${ }^{336}$

Of interest are forms of learned influence which one may plausibly associate with Rheims or St-Bertin. For the introduction to Alfred's law-book strong arguments have been made for regarding the treatment of the relationship between divine and secular law, and the

330 Ibid., pp. 10-11. Keynes and Lapidge, Alfred, pp. 332-3, n. 10; Pratt, Political Thought, pp. 211-12. Cf. Nelson, 'Fulk's Letter to Alfred Revisited', pp. 142-3.

331 Councils 871-1066, p. 11.

332 P. Grierson, 'Grimbald of St Bertin's', EHR 55 (1940), 529-61, at 530-40; S. Keynes, The Liber Vitae of the New Minster and Hyde Abbey, Winchester, EEMF 26 (Copenhagen, 1996), 16-17.

333 Brooks, Canterbury, pp. 152-3.

334 'Quorum doctrina regis ingenium multum dilatatum est': Asser, Vita Alfredi, c. 78 (ed. Stevenson, p. 63; Keynes and Lapidge, Alfred, p. 93).

335 On manuscripts, see Keynes and Lapidge, Alfred, p. 214, n. 26; M. Lapidge, The Anglo-Saxon Library (Oxford, 2006), pp. 48-9.

336 J. M. Bately, 'Did King Alfred Actually Translate Anything? The Integrity of the Alfredian Canon Revisited', MAE 78 (2009). 189-215, at 209; idem, 'Alfred as Author and Translator', A Companion to Alfred, ed. Discenza and Szarmach, pp. 113-42, esp. 127 and 141-2. See also D. Pratt, 'Problems of Authorship and Audience in the Writings of King Alfred the Great', Lay Intellectuals in the Carolingian World, ed. P. Wormald and J. L. Nelson (Cambridge, 2007), pp. 162-91, esp. 167-9. 
historical development of secular law, as heavily influenced by Hincmarian principles and as responding to Fulk's letter to King Alfred, which makes much use of his predecessor's legal teaching. ${ }^{337}$ That Fulk should highlight Grimbald's expertise in ecclesiastical law strengthens the case for suspecting some direct contribution by Grimbald to the ideas represented in the introduction. A similar instance is the distinctively Alfredian language of wealth and wisdom, dependent on the example of King Solomon - what I have called the language of Solomon's dream - prominent in the Prose Preface, in the translations of the Consolatio Philosophiae and Soliloquia, and also used by Asser. ${ }^{338}$ As I have shown, the language was of specifically West Frankish derivation, regularly being deployed in dedicatory biblical poems and other material addressed to Charles the Bald. ${ }^{339}$ The case for Grimbald's specific involvement is strengthened by the centrality of Solomonic imagery in Hincmarian legal theory, and by the use of this language by the scholar and teacher Hucbald of St-Amand. ${ }^{340}$ Hucbald is known to have spent time at St-Bertin in the later 880s, where he was recruited for the personal tuition of Rodulf as lay-abbot: it is possible that Grimbald may have encountered Hucbald before his departure for England. 341

Influences mediated through St-Bertin and/or Rheims may also be suspected for the translation of the Consolatio. The appeal to the three orders of society in an important passage of departure must reflect influences ultimately derived from the school of Auxerre, where the idea of the three orders was first developed by Haimo of Auxerre and his pupil Heiric. ${ }^{342}$ The presence of Heiric's pupil, Hucbald, at St-Bertin provides one plausible means of transmission. Also relevant is the recruitment of Heiric's two pupils, Hucbald and Remigius of Auxerre, by Fulk to teach at Rheims, probably in the early 890s: the dating is problematic, but Hucbald at least is unlikely to have left St-Bertin before the death of Rodulf in $892 .{ }^{343}$ Remigius has long dominated discussion of the commentary material associated

\footnotetext{
337 Pratt, Political Thought, pp. 223-30; Wormald, Making of English Law I, 227-8 and 423-7. Cf. B. Carella, 'Evidence for Hiberno-Latin Thought in the Prologue to the Laws of Alfred', SP 108 (2011), 1-26, expressing doubt over the degree of knowledge of Hincmarian ideas in the law-book beyond those present in Fulk's letter, the influence of which is accepted. Carella's appeal to a lack of full textual dependence on a Hincmarian source lacks weight since the matter also relates to Grimbald's probable awareness of Hincmarian ideas, which might have found expression in less direct ways. To cite just one example, the Alfredian statement that a man who follows the 'Golden Rule' 'needs no other judgement book' (ne ðearf he nanra domboca operra) is strongly reminiscent of Hincmar's view, ultimately derived from I Timothy I. 9, that a just man may technically be regarded as not subject to law: F. Liebermann, Die Gesetze der Angelsachsen, 3 vols. (Halle, 1903-16) I, 44 (Int.49.6); Pratt, Political Thought, p. 224, with references. One should not be troubled by the citing of the 'Golden Rule' in its variant, negative form: cf. B. Carella, 'Asser's Bible and the Prologue to the Laws of Alfred', Anglia 130 (2012), 195-206, at 202-5. There is no reason to regard putative Frankish, Irish or other intellectual contexts for the law-book as mutually exclusive.

338 Pratt, Political Thought, pp. 151-7, 280-7, 292-5, 300-2, 318-20 and 328-9.

339 Ibid., pp. 158-66 and 353-5.

340 Ibid., pp. 160-1 and 354-5.

341 Ibid., pp. 161-2.

342 J. L. Nelson, 'The Political Ideas of Alfred of Wessex', in her Rulers and Ruling Families, no. IV, pp. 12558, at 141-3; Pratt, Political Thought, pp. 292-3.

343 Pratt, Political Thought, pp. 161-2 and 273.
} 
with the Carolingian transmission of the Latin Consolatio, through the association of his name with certain glosses. From the recent study of the commentaries, it is clear that material conventionally identified as 'Remigian' should be regarded as a broader tradition of commentary and glossing emanating from the school of Auxerre, probably reflecting the teaching of Haimo and Heiric. ${ }^{344}$ In their edition of the translation, Godden and Jayatilaka have identified over thirty places where the influence of commentary material may be very strongly suspected, noting parallels with a strand of glossing in late tenth- and early eleventhcentury manuscripts from England. ${ }^{345}$ As Rosalind Love has commented, 'There is no difficulty with this conclusion, since [...] the intertwined layers of annotation in those books transmit the work of earlier glossators from diverse sources, and contain unmistakeable indications that they drew on glossed books or sets of glosses that have since been lost'. ${ }^{346}$ The chain of connections between Auxerre, St-Bertin and Rheims suggest channels by which such material could have reached Alfred's circle. ${ }^{347}$

One should note other signs of Frankish influence which it is tempting to associate with Grimbald. As Patrick O'Neill has observed, although the translation of the first fifty Psalms generally follows the Roman Psalter, on some 140 occasions the translation takes account of readings from the Gallican Psalter, then favoured in the Frankish church. ${ }^{348}$ O'Neill has advanced credible arguments for identifying Grimbald as an early champion of the Gallican Psalter in England, a view which would associate Grimbald, significantly, with liturgical reform. ${ }^{349}$ In the translation of the Soliloquia, plausible parallels have been drawn with the eschatology of John Scottus Eriugena: the suggestion remains speculative, but if there had been any role for Eriugenan influence, Grimbald would again be a possible intermediary. 350

344 R. Love, 'Latin Commentaries on Boethius's Consolation of Philosophy', A Companion to Alfred, ed. Discenza and Szarmach, pp. 82-110, at 89-94.

345 The Old English Boethius: an Edition of the Old English Versions of Boethius's De Consolatione Philosophiae, ed. M. Godden and S. Irvine, 2 vols. (Oxford, 2009) I, 55.

346 Love, 'Latin Commentaries', p. 98.

347 Ibid., pp. 96-7 and 107-8.

348 P. P. O'Neill, King Alfred's Old English Prose Translation of the First Fifty Psalms (Cambridge, MA, 2001), pp. 32-4.

349 P. P. O'Neill, 'On the Date, Provenance and Relationship of the "Solomon and Saturn" Dialogues' ASE 26 (1997), 139-68, at 158-64.

350 M. Treschow, 'Echoes of the Periphyseon in the Third Book of Alfred's Soliloquies', N\&Q 238 (1993), 2816. Cf. Pratt, Political Thought, pp. 315-17. Early knowledge of Eriugenan thought in England is indicated by Cambridge, Corpus Christi College 223 (St-Vaast, Arras, s. ix ${ }^{3 / 4}$; St-Bertin provenance s. ix ${ }^{e x}$, in England by s. $\mathrm{x}^{1 / 2}$ ), a Prudentius manuscript also containing Aulae siderae (pp. 332-4), an important example of Eriugena's court poetry for Charles the Bald, probably composed to celebrate the founding of Charles's palace chapel at Compiègne in 870. Gneuss, Handlist, no. 70; Ker, Catalogue, p. 92 (no. 52); Lapidge, The Anglo-Saxon Library, p. 167; N. Staubach, Rex Christianus: Hofkultur und Herrschaftspropaganda im Reich Karls des Kahlen - Teil II: Grundlegung der 'religion royale', Pictura et Poesis II/2 (Cologne, Weimar and Vienna, 1993), 75-86 and 269-7. 
Especially striking are the Solomonic and liturgical dimensions of Frankish influence, which render credible a role for Grimbald in coronation ordines. Comparable liturgical interchange between England and northern Francia is well documented, since, of the two key Frankish pontificals containing English ordines, 'Leofric A' was in all likelihood written in the Arras/Cambrai region, travelling to south-western Francia and then Canterbury by the 920s, while the Sacramentary of Ratold, written in northern Francia before 986, incorporated the text of a pontifical of mid or later tenth-century English origin but had a calendar and masses deriving from St-Vaast. ${ }^{351}$ Grimbald's involvement in Alfredian learning should be set alongside the documented Alfredian interest in contemporary West Frankish politics, and the hints that Charles the Straightforward's anointing had been seen as significant. Such interest might easily have included acquisition of the latest West Frankish ordo, probably put together by Fulk. Grimbald should therefore be seen as the likely means by which the Leiden Ordo, and by implication the other sources for the Second Ordo, reached England. This has a bearing on the compilation of the Second Ordo, since the main intervention involved in the Second Ordo was the supplementing of the First Ordo with formulas largely borrowed from these West Frankish sources. One might assume Canterbury's oversight of royal ordines, given the archbishop's responsibility for conducting the ritual, but account should also be taken of the close relationship between the Second Ordo and recent West Frankish ordines. With his background and connections, liturgical expertise and important ecclesiastical position in Alfred's kingdom, there is an attractive case for suspecting Grimbald's involvement in the compilation of the Second Ordo.

\section{THE DATING OF THE SECOND ORDO: NEGATIVE ARGUMENTS}

The argument above has related the circumstances of Charles the Straightforward's anointing in 893 to King Alfred's network of cross-Channel contacts. Building on the identification of the Leiden Ordo as that used for Charles, the argument has identified certain features of Alfredian cross-Channel connections which render it plausible to envisage that the Ordo had been imported into England at an early stage, enabling the Second Ordo to have been drafted in the mid or late 890s. The argument depends upon a number of considerations, but must also be understood as appealing to the balance of probabilities. Notwithstanding the case which has been made, the identification proposed for the Leiden Ordo might still appear to leave open the possibility of a later scenario for the drafting of the Second Ordo, in the period preceding Æthelstan's anointing in 925. It is important to address such a later scenario, since Continental contacts continued, and Nelson has herself noted the dynastic connection arising from the marriage of Charles the Straightforward, as West Frankish king, to Eadgifu,

351 See above, pp. 00-00/16-17. 
daughter of Edward the Elder in the later 910s. ${ }^{352}$ The notion that the Second Ordo might be better located early in Æthelstan's reign has, additionally, received credence from the iconography of his coingage which, from the early 930s, incorporated a portrait of the king's crowned bust. In order to support the positive arguments for compilation under Alfred, it is therefore necessary to reconsider the view derived from Æthelstan's coinage, and to advance some objections to a later dating.

\section{Royal portrait types on coinage}

The iconography of Æthelstan's coinage might appear to suggest new attitudes to the regalia. Up until c. 880, the obverse of southern English pennies had mainly taken the form of a king's bust wearing a diadem. ${ }^{353}$ Alfred's Two-Line type established a tradition of nonportrait obverses; both portrait and non-portrait types were employed under Edward. ${ }^{354}$ Æthelstan's first major new issue, the Circumscription Cross type, bore no portrait but accorded the king the grandiose title rex tot[ius] Brit[anniae], on which basis it may be dated to the period following his takeover of Northumbria in 927.355 Significantly, the next type for Wessex, Kent, London and East Anglia, introduced in the early 930s, reinstated a portrait obverse, but in this case depicting the king wearing a crown with three prongs, each terminating in a circular ball. ${ }^{356}$ The Bust Crowned type remained the main form of portrait on coinage until Edgar's reform. ${ }^{357}$ Although the imagery bears a relationship to late Roman imperial coinage, the form of crown appears distinctive, and commentators have noted the resemblance to the crown worn by Æthelstan in the celebrated ruler-portrait in Cambridge, Corpus Christi College 183, a book brought to completion in the period June 934 - October 939.358

\footnotetext{
352 Nelson, 'The First Use of the Second Anglo-Saxon Ordo', pp. 125-6.

353 M. Blackburn and S. Keynes, 'A Corpus of the Cross-and-Lozenge and Related Coinages of Alfred, Ceolwulf II and Archbishop Æthelred', Kings, Currency and Alliances, ed. Blackburn and Dumville, pp. 12550 and Plates 1-11, at 130-2, 134-5, 138 and 143.

354 M. Blackburn, 'The London Mint in the Reign of Alfred', Kings, Currency and Alliances, ed. Blackburn and Dumville, pp. 105-23, at 107 and 120-2; S. Lyon, 'The Coinage of Edward the Elder', Edward the Elder, ed. Higham and Hill, pp. 67-78; R. Naismith, Medieval European Coinage 8. Britain and Ireland c. 400-1066 (Cambridge, 2017), 181-3 and 195.

355 C. E. Blunt, 'The Coinage of Athelstan, 924-39: a Survey', BNJ 42 (1974), 35-160, at 47, and 55-7; C. E. Blunt, B. H. I. H. Stewart and C. S. S. Lyon, Coinage in Tenth-Century England from Edward the Elder to Edgar's Reform (Oxford, 1989), pp. 108-9; Naismith, Medieval European Coinage 8, 202-3.

356 Blunt, 'Coinage of Athelstan', pp. 47-8, 57 and 61; Blunt et al., Coinage in Tenth-Century England, pp. 108-9; Foot, AEthelstan, pp. 155-6, cf. 216-21; W. J. Andrew, 'Evolution of Portraiture on the Silver Penny', BNJ 5 (1908), 360-80, at 366-7; Naismith, Medieval European Coinage 8, 182 and 203-4.

357 Blunt et al., Coinage in Tenth-Century England, pp. 191-201; R. Naismith, 'Prelude to Reform: TenthCentury English Coinage in Perspective', Early Medieval Monetary History: Studies in memory of Mark Blackburn, ed. R. Naismith, M. Allen and E Screen (Farnham, 2014), pp. 39-83, at 46-52; Naismith, Medieval European Coinage 8, 181-3 and 195-210.

358 Blunt, 'Coinage of Athelstan', pp. 47-8; C. E. Karkov, The Ruler Portraits of Anglo-Saxon England (Woodbridge, 2004), pp. 66-7; Maddicott, Origins of the English Parliament, p. 20; Foot, Athelstan, pp. 156;
} 
Nelson has suggested that the new coin type might have related to the Second Ordo, since, if it had been drafted for Æthelstan's coronation, the replacing of the helmet of the First Ordo with a crown would have been a recent innovation. ${ }^{359}$ The idea that the crown had special significance under Æthelstan has been taken further, with Wormald, Maddicott and Foot postulating that Æthelstan's royal assemblies may have been occasions for crownwearing. 360 A separate but aligned argument has concerned the regnal list on a leaf (now London, British Library, Cotton Tiberius A. iii, fol. 178) which originally followed the Bmanuscript of the Chronicle. ${ }^{361}$ A continuation of the West Saxon regnal list of the late ninth century, and written by the same scribe as the rest of the B-manuscript, probably during the reign of Edward the Martyr, the list implies an awareness of coronations since, for recent kings, it gives reign-lengths seemingly calculated from a date of election or coronation, rather than from the death of a predecessor. ${ }^{362}$ Garnett has argued that, since the reign-length for Æthelstan is the first to be recorded to the nearest week and day, this would suggest that the 920s were later thought to have been the period of significant change. ${ }^{363}$

The Bust Crowned type was clearly an important iconographic development, but there are difficulties in assessing its import. One faces the lack of surviving portraits in manuscripts of rulers earlier than Æthelstan, such that one cannot determine the novelty of his depiction wearing a crown in CCCC 183. There are basic uncertainties over royal headgear before the Second Ordo: while the First Ordo provides for a helmet, the wider use of which is supported by linguistic considerations, a single reference in the Liber pontificalis reveals that King Æthelwulf's gifts to St Peter in 855 included a crown in fine gold weighing four pounds. ${ }^{364}$ Nor should one necessarily expect to find a king depicted on coinage with regalia as used in inauguration. Kings typically wore diadems on coinage in the ninth and early tenth centuries; a further complicating feature is the interest in late Roman coin designs, especially marked during Alfred's reign. ${ }^{365}$ Yet, for as long as the First Ordo remained in use, kings appear to

Naismith, Medieval European Coinage 8, 203. For CCCC 183, see Keynes, 'King Athelstan's Books', pp. 181-2.

359 Nelson, 'The First Use of the Second Anglo-Saxon Ordo', pp. 124-5.

360 Wormald, Making of English Law I, 444-8; Maddicott, Origins of the English Parliament, pp. 18-21; Foot, Ethelstan, pp. 221-2.

361 The Anglo-Saxon Chronicle MS B, ed. S. Taylor, The Anglo-Saxon Chronicle: a Collaborative Edition, ed. D. Dumville and S. Keynes 4 (Cambridge, 1983), 56-8, cf. xvi-xxiv; Anglo-Saxon Chronicle, ed. Whitelock et al., pp. 4-5, cf. p. 3.

362 Keynes, 'Church Councils, Royal Assemblies', pp. 148-9.

363 Garnett, 'Coronation', p. 125.

364 Nelson, 'The Earliest Surviving Royal Ordo', pp. 356-8. Liber pontificalis CVI.34 (Le Liber Pontificalis: Texte, introduction et commentaire, ed. L. Duchesne, 2 vols. (Paris, 1886-92) II, 148). Scharer, 'King Alfred and Late Carolingian Europe', pp. 8-9; idem, 'Objects of Royal Representation', pp. 41-2.

365 Blackburn, 'The London Mint', pp. 113-14; Keynes, 'Alfred the Great and the Kingdom of the AngloSaxons', pp. 21 and 25; Naismith, Medieval European Coinage 8, 168-9. For the Watlington hoard, see Naismith, 'Evidence of an Anglo-Saxon Alliance', p. 5. 
have been invested with a helmet. 366 Overall, therefore, Æthelstan's representation in rulerportraits confirms that the crown had come into use by the early 930s, but cannot reveal when. It is perfectly possible that the crown had entered the regalia in the late ninth or early tenth centuries, only to reach the visual record in the 930s.

Nor can one safely regard Æthelstan's reign as a period of innovation in respect of crown-wearing. Michael Hare has advanced an attractive argument that the ritual of crownwearing may have been known in later Anglo-Saxon England, but the best early evidence concerns Eadred and Edgar.367 Grounds for associating crown-wearing with Æthelstan specifically have been adduced from his holding of royal assemblies on the occasion of major religious festivals, but allowances should be made for the highly unusual sequence of ' Ethelstan A' diplomas, which allow assemblies to be dated and located with greater precision. 368 Chronologically, some years separated Æthelstan's coronation from the Bust Crowned type, and if, as seems likely, the unusual depiction had some specific rationale, one might consider the general conditions of the early 930s. This was a period of continuing succcess for Æthelstan's rule and, as shown by the sequence of law-codes and by the diplomas of ' $E$ thelstan A', one characterized by attention to administration and peacekeeping. ${ }^{369}$ One might regard the new type as a further celebration of Æthelstan's wider rule, or as an expression of royal ambitions in government; another relevant development may be practices of liturgical commemoration associated with the king's legal reforms. ${ }^{370}$ The regnal list in Tiberius A. iii may, moreoever, be interpreted differently: as Whitelock pointed out, the reign-length of 24 years assigned to Edward would be nearly correct if calculated on the same basis, from coronation to death (8 June 900 - 17 July 924). ${ }^{371}$ The list reflected information beyond what was available in the Chronicle; this reading would have the advantage of implying a consistent basis for the treatment of reigns that were additional to the compiler's

\footnotetext{
366 For a minor coin type under Æthelstan and Edmund, associated with the north-east midlands, depicting the king wearing a crown over what may be a helmet, see Blunt, 'Coinage of Athelstan', pp. 48 and 83-5; Blunt $e t$ al., Coinage in Tenth-Century England, p. 191; Naismith, Medieval European Coinage 8, 202 and 204-5.

367 M. Hare, 'Kings, Crowns and Festivals: the Origins of Gloucester as a Royal Ceremonial Centre', Trans. of the Bristol and Gloucestershire Archaeol. Soc. 115 (1997), 41-78, at 44-52, esp. 45, citing S 549 (Burt 8). See also M. Biddle, 'Seasonal Festivals and Residence: Winchester, Westminster and Gloucester in the Tenth and Eleventh Centuries', ANS 8 (1985), 51-72.

368 Wormald, Making of English Law I, 444-8; Maddicott, Origins of the English Parliament, pp. 18-21, cf. 1214; Foot, Ethelstan, pp. 221-2. Cf. Hare, 'Kings, Crowns and Festivals', pp. 46-8. For the 'Æthelstan A' diplomas, see Keynes, 'England, c. 900-1016', p. 470; idem, 'Church Councils, Royal Assemblies', pp. 35-7, 53-5, 77 and 169.

369 Foot, Athelstan, pp. 70-3 and 136-48; Keynes, 'England, c. 900-1016', pp. 470-1; S. Keynes, 'Royal Government and the Written Word in Late Anglo-Saxon England', The Uses of Literacy in Early Medieval Europe, ed. R. McKitterick (Cambridge, 1990), pp. 226-57, at 235-41; D. Pratt, 'Written Law and the Communication of Authority in Tenth-Century England', England and the Continent, ed. Rollason et al., pp. 331-50, at 335-50.

370 Keynes, 'Royal Government', pp. 237-8; Pratt, 'Written Law', p. 346; D. Pratt, 'Kings and Books in AngloSaxon England', ASE 43 (2015), 297-377, at 342.

371 Anglo-Saxon Chronicle, ed. Whitelock et al., p. 4, n. 10.
} 
source. Æthelstan's coinage can therefore provide only a terminus ante quem for the replacing of helmet with crown.

\section{West Frankish circumstances early in AEthelstan's reign}

There are, additionally, several objections to the possible dating of the Second Ordo early in Fthelstan's reign. The temporal proximity of the Leiden Ordo (893) and the Erdmann Ordo (c. 880) renders such a scenario problematic. There was a lengthy gap in West Frankish kingly anointings between 893 and the early 920s, and the rite probably used in West Francia in the early 920s was the Erdmann Ordo, since both rituals were conducted by archbishop Walter of Sens. ${ }^{372}$ Moreover, in June 922 Charles the Straightforward had been overthrown, and in 923, after a short-lived attempt to regain power, he faced imprisonment, his wife Eadgifu subsequently sending his infant son, Louis 'd'Outremer' to the court of Æthelstan, for protection. ${ }^{373}$ While Charles's marriage or Louis's exile might have provided a means for the Leiden Ordo to reach England, such a scenario seems less likely than that of early importation after 893. By 924 x 925, the fortunes of Charles's family were at a low ebb, and distant from the claims of rulership over the Franks and Aquitanians probably advanced in 893. Although, as MacLean has argued, Louis's presence in England might help to make sense of the marriages of Æthelstan's half-sisters, especially that of Edith to Hugh the Great in 926, his analysis suggests a later turning-point in Louis's prospects, in 928: a set of agreements which may have paved the way for Louis's return as West Frankish king in 936. 374 Furthermore, Louis's mother, Eadgifu, was among the offspring of Edward the Elder's second wife, Ælfflæd: in 924-5, Æthelstan's path to kingship had been obstructed by two of Ælfflæd's sons, Ælfweard and then Edwin, circumstances potentially difficult for Eadgifu and Louis. ${ }^{375}$ On the arguments developed here, it was the idea of rule over two peoples in the Leiden Ordo that had captured the attention of the compiler of the Second Ordo, yet such claims on Charles's part were no longer current in the West Francia of the mid 920s.

The point is further illustrated by the subsequent development of the Ordo of Seven Forms. As noted above, Nelson's case for associating the full Ordo of Seven Forms with Louis's anointing in 936, and that of his queen, Gerberga, in 939, is strengthened by the understanding that Seven Forms represented a revised version of the earlier Leiden Ordo. ${ }^{376}$ Yet one of the most important changes that distinguished Seven Forms from its forbear was the removal of the references to Franks and Aquitanians, and to two peoples, making the

\footnotetext{
372 Bautier, 'Sacres et couronnements', pp. 49-50; Nelson, 'Early Medieval Rites of Queen-Making', pp. 31011. See above, pp. 00-00/23-5.

373 Dunbabin, 'West Francia: the Kingdom', pp. 376-9; MacLean, 'Cross-Channel Marriage', pp. 30-4.

374 MacLean, 'Cross-Channel Marriage', pp. 34-40, esp. 34-5.

375 See below, pp. 00-00/64-5.

376 Nelson, 'Early Medieval Rites of Queen-Making', pp. 311-12. See above, p. 00/42.
} 
anointing prayer effectively neutral. ${ }^{377}$ One may also consider the Continental transmission of the Second Ordo, since Louis's reign (936-54) has often been suggested as a likely setting for the importing of the Second Ordo to West Francia. ${ }^{378}$ Such a hypothesis presents some difficulties: the English pontifical underlying the Sacramentary of Ratold seems more likely to have been produced in the period c. 960 - c. 980.379 In the case of the 'SMN' text, the earliest manuscript, the Pontifical of Trier, dates from the eleventh century, and later manuscripts appear to have descended from a copy of that pontifical's exemplar; the derivation of the imported text remains uncertain. ${ }^{380}$ It is in any case striking that the Continental transmission of the Second Ordo gives no indication that the West Frankish origins of the anointing prayer had been recognized by copyists: rather, there were partial attempts to disguise the references to 'Albion' and to 'Saxons, Mercians and Northumbrians', whereas in respect of rulership over two peoples the reading 'ut utrorumque horum populorum' was retained. The memory of Charles's rule over two peoples appears to have been subsequently obscured.

\section{The longevity of the 'kingdom of the Anglo-Saxons'}

The hypothetical production of an ordo promoting the kingship of 'Angles' and 'Saxons' in 924 x 925 would be problematic since by this point the 'kingdom of the Anglo-Saxons' had been in existence for over forty years. It had been formed in the early 880s, and the central expressions of the new kingdom came at an early stage. ${ }^{381}$ The efforts to promote the new identity of the kingdom comprised Alfred's new styling in diplomas; the events of 886, when Alfred 'occupied' London and received a widespread submission; Alfred's law-book, which showed respect for Mercian legal tradition; and probably also the 'common stock' of the Chronicle. ${ }^{382}$ As Keynes has pointed out, the title 'king of the Anglo-Saxons' was retained by Edward the Elder, and, significantly, Æthelstan was accorded the same title early in his reign, before his takeover of Northumbria in 927.383 In other words, kingship over the 'AngloSaxons' was the standard means of conceptualizing the southern kingdom ruled by Alfred

\footnotetext{
377 The two prayers may be compared by means of the Appendix: see below, pp. 00-00/93-101.

378 Turner, Claudius Pontificals, p. xxxiii; Hohler, 'Some Service Books', pp. 68-9; Nelson, 'The Second English Ordo', pp. 368-9; idem, 'The First Use of the Second Anglo-Saxon Ordo', pp. 117 and 124; Garnett, 'Coronation', p. 125.

379 See above, p. 00/17, n. 113.

380 Paris, Bibliothèque nationale de France, lat. 14192. V. Leroquais, Les Pontificaux manuscrits des bibliothèques publiques de France, 4 vols. (Paris 1937) II, 175-9 (no. 151). Jackson, Ordines, pp. 169-70, 173 and 175-6. For the transmission of one version of the Ordo in the twelfth century, see Brown, 'Franks, Burgundians and Aquitanians', pp. 15-53.

381 Keynes, 'King Alfred and the Mercians', pp. 19-45; idem, 'Alfred the Great and the Kingdom of the AngloSaxons', pp. 22-6, 34-6 and 40.

382 See below, p. 00/71.

383 Keynes, 'Edward, King of the Anglo-Saxons', pp. 51-4, cf. 57-62; idem, Keynes, 'England, c. 900-1016', p. 468.
} 
and his successors between $c .880$ and 927.384 A hypothetical date for the Second Ordo of 924 x 925 would postulate an attempt to promote 'Anglo-Saxon' kingship long after Alfredian efforts had had their effect.

The suggestion that the Second Ordo might fit the politics of 924-5 relies on a reconstruction of the circumstances of Æthelstan's accession which is by no means certain. ${ }^{385}$ Any arrangements made for the future during Edward's lifetime are unknown. Whereas Æthelstan, probably brought up in Mercia, might be expected to have had political support in that region, it is clear that Ælfweard, the son of Edward's second wife, Ælfflæd, was also regarded as a claimant, probably receiving strong support in Winchester. ${ }^{386}$ In the event, Ælfweard's kingship was recognized after Edward's death on 17 July 924, but he died in early August. ${ }^{387}$ It is difficult to know what form of rule Ælfweard was accorded. The possibility that Ælfweard's kingship had been restricted to Wessex arises from two features of the evidence: firstly, the report in the Mercian Register that ' $Æ$ thelstan was chosen by the Mercians as king, and consecrated at Kingston', and, secondly, signs that Æthelstan's rule had initially faced some opposition in Wessex, centred on Winchester and supporting the claim of Ælfflæd's surviving son, Edwin. ${ }^{388}$ Yet, although it is clear that Æthelstan faced some difficulties in imposing his authority on Wessex after Ælfweard's death, it seems likely that he claimed rule over the entirety of Edward's kingdom. An important diploma from 925 records Æthelstan's presence at what appears to have been a 'Mercian' assembly, yet describes Æthelstan as tociusque climatis ferme cataclismatum gurgitibus Cristiane patrigene preuisor ("supervisor of the Christian household of the whole region well-nigh in the whirlpools of cataclysms'). ${ }^{389}$ The reference to the 'whole region', combined with the exceptional styling, rex Anglorum, suggests a comprehensive claim. ${ }^{390}$ Although the Mercian Register might be read as implying that Æthelstan had initially been 'chosen' as king by the Mercians only, the entry might alternatively be interpreted as reporting, from a Mercian

384 Keynes, 'Edward, King of the Anglo-Saxons', p. 57; idem, 'Alfred the Great and the Kingdom of the AngloSaxons', pp. 40-1.

385 For discussion, see B. Yorke, 'Æthelwold and the Politics of the Tenth Century', Bishop AEthelwold, ed. Yorke, pp. 65-88, at 70-3; Keynes, Liber Vitae, pp. 19-21; idem, 'England, c. 900-1016', pp. 467-8; Foot, Ethelstan, pp. 37-43.

386 Yorke, 'Ethelwold and the Politics of the Tenth Century', pp. 70-3; Keynes, Liber Vitae, pp. 19-21.

387 Keynes, 'The Burial of King Æthelred', pp. 133-4. The West Saxon regnal list in the Textus Roffensis includes Ælfweard, assigning him a reign of four weeks. According to William of Malmesbury, Ælfweard (whom William consistently calls Æthelweard) 'recalled his grandfather Alfred in appearance and character': Gesta regum II.126 (ed. Mynors, et al. I, 198).

388 ASC 924 BCD: Two Chronicles, ed. Plummer I, 105 (text); Anglo-Saxon Chronicle, ed. Whitelock et al., p. 68 (translation). Yorke, 'Æthelwold and the Politics of the Tenth Century', pp. 71-3; Keynes, Liber Vitae, pp. 19-21.

${ }^{389}$ S 395 (Burt 2). Keynes, Liber Vitae, pp. 19-20; idem, ‘England, c. 900-1016’, pp. 467-8.

390 Cf. Molyneaux, Formation of the English Kingdom, p. 29. 
perspective, the subsequent establishment of his authority over the whole kingdom. ${ }^{391}$ The latter reading has some attractions, since the annal is the final entry in the Register, and the report of Æthelstan's anointing might be read as appropriately concluding the Register's account of 'Mercian' political agency. ${ }^{392}$ That Ælfweard had himself died in Mercia, at Oxford, strengthens the suspicion that his claim had related to the 'kingdom of the AngloSaxons', rather than to Wessex only. 393

Rather than the straightforward political division of Edward's kingdom into 'Wessex' and 'Mercia', therefore, the events of 924-5 seem more likely to have involved competing claims to rule over Edward's 'Anglo-Saxon' kingdom. While the support for rival claimants had regional dimensions, the matter was probably more complex. Although Æthelstan had support in Mercia, his success suggests an ability to muster backing in Wessex, and, if the above interpretation of the Mercian Register is accepted, his formal 'choosing' as king appears to have postdated Ælfweard's death. ${ }^{394}$ Arguments for the drafting of the Second Ordo on Æthelstan's behalf have postulated some form of division of the kingdom, to give force to the language of the anointing prayer, but if, as here argued, that seems less likely, one may wonder how far the unity of two peoples, the rule over 'Angles' and 'Saxons', needed promoting in 925.395 It is a matter of emphasis, but there may be dangers in postulating a major breach in the identity of the kingdom as rival claims were pursued. In ruling, before 927, as 'king of the Anglo-Saxons', Æthelstan bore the title accorded to his father and grandfather.

\section{The queen's ordo and dynastic considerations}

The hypothetical production of the Second Ordo for Æthelstan faces difficulties arising from the treatment of queenship. The Second Ordo probably represented a major step away from previous West Saxon practices in relation to the 'king's wife', because of the inclusion of a queen's ordo. 396 Nelson notes that Æthelstan had been unmarried, but suggests that the queen's ordo need not be decisive, since it could represent a subsequent addition to the rite used for Æthelstan. ${ }^{397}$ Technically, this is an arguable position, but it faces the difficulty that

391 D. N. Dumville, Wessex and England from Alfred to Edgar (Woodbridge, 1992), p. 93, n. 191, cf. pp. 1456.

392 For valuable discussion of the Mercian Register, see P. E. Szarmach, 'Æthelflæd of Mercia: Mise en page’, Words and Works: Studies in honour of Fred C. Robinson, ed. P. S. Baker and N. Howe (Toronto, 1998), pp. $105-26$.

393 ASC 924 BCD: Two Chronicles, ed. Plummer I, 105 (text); Anglo-Saxon Chronicle, ed. Whitelock et al., p. 68 (translation)

394 For Æthelstan's favourable relations with Malmesbury, and appointments to high ecclesiastical office in Wessex, see Yorke, 'Æthelwold and the Politics of the Tenth Century', pp. 71 and 73.

395 Nelson, 'The First Use of the Second Anglo-Saxon Ordo', p. 124; Wormald, Making of English Law I, 447, n. 114.

396 See above, pp. 00-00/13-14 and 00/22.

${ }^{397}$ Nelson, 'The First Use of the Second Anglo-Saxon Ordo', pp. 123-4. 
the queen's ordo seems more likely to have been an integral part of the Second Ordo. The king's ordo is not known to have circulated separately, while the queen's ordo occupies an intermediate position in the text, preceding the Mass settings for the king's ordo: its nearexclusive dependence on the Erdmann Ordo again suggests a single process of compilation. The hypothesis of 924 x 925 thus seems difficult to reconcile with the novelty represented by the queen's ordo: the scenario would involve an upgrading of queenly status which lacked an immediate purpose. Although the queen's ordo mainly followed that of Erdmann, a number of textual departures indicate a process of adaptation comparable to the handling of sources in the main royal ordo. 398 The point is not decisive, but suggests that the drafting of the queen's ordo was more than a paper exercise.

The hypothesis of compilation for Æthelstan faces a further difficulty from broader considerations relating to the status of consorts. Unfortunately, apart from the case of Judith, there is little direct evidence for the anointing of a queen in the Anglo-Saxon period, but this may be because the practice became routine, not receiving comment in narrative sources. ${ }^{399}$ The existence of the Second Ordo strongly implies that, from the time of its compilation, queens were regularly anointed. Furthermore, as Stafford has shown, using the evidence of charter attestations and references in narrative sources, there are indications of a rise in the status of consorts in the tenth century, exemplified by the career of King Edgar's third wife, Elfthryth. ${ }^{400}$ The problem is that this broader picture is difficult to reconcile with a scenario in which queenly anointing had been introduced after 925. Of particular significance is the career of Edward the Elder's third wife, Eadgifu, who married the king in the later 910s. ${ }^{401}$ The mother of Edmund (939-46) and Eadred (946-55), Eadgifu held strong political influence during the reigns of her sons, and her career continued into the 960s. Unusually among consorts, Eadgifu has a prominent presence in the witness-lists of diplomas, consistently attesting during the reigns of her sons with the title mater regis. ${ }^{402}$ Moreover, whereas Eadred

\footnotetext{
398 Nelson, 'The Second English Ordo', p. 367; Pratt, English Coronation Ordines.

399 For relevant discussion, cf. Stafford, 'The King's Wife in Wessex', pp. 16-18; idem, Queen Emma and Queen Edith, pp. 62-3 and 165-8. For Edith, see ASC 1048 E (= 1051): The Anglo-Saxon Chronicle MS E, ed. S. Irvine, The Anglo-Saxon Chronicle: a Collaborative Edition, ed. D. Dumville and S. Keynes 7 (Cambridge, 2004), 82 (text); Anglo-Saxon Chronicle, ed. Whitelock et al., p. 121 (translation). For Ælfthryth, see below, pp. 00-00/69-70. Cf. Byrhtferth of Ramsey, Vita S. Oswaldi IV.6-7, in Byrhtferth of Ramsey: the Lives of St Oswald and St Ecgwine, ed. M. Lapidge (Oxford, 2009), pp. 104-10, who describes Edgar's consecration in 973 in terms which have been taken to imply that Ælfthryth had been anointed on the same occasion, but his account mechanistically follows the B-version of the Second Ordo (Lapidge, Byrhtferth of Ramsey: the Lives of St Oswald and St Ecgwine, pp. 107-8, n. 59 and pp. 110-11, n. 69; cf. Nelson, 'The Second English Ordo', pp. 372-4). In view of the problems posed more generally by Byrhtferth's handling of chronology and detail, it is doubtful whether his version offers material of independent value for the understanding of the events of that year. I hope to return to this and related issues elsewhere.

400 Stafford, 'The King's Wife in Wessex', pp. 4-7, 15-18 and 20-27; idem, Queen Emma and Queen Edith, pp. 62-4, 70-2, 165-9 amd 197-206.

401 P. Stafford, 'Eadgifu ( $b$. in or before 904, $d$. in or after 966)', ODNB.

402 S. Keynes, An Atlas of Attestations in Anglo-Saxon Charters, c. 670-1066 (Cambridge, 2002), Table XXXIa.
} 
remained unmarried, Edmund had two wives, Ælfgifu (d. 944) and Æthelflæd of Damerham, whom he married after Ælfgifu's death. 403 What makes Eadgifu's attestations especially striking is the absence from witness-lists during Edmund's reign of Ælfgifu and Æthelflæd of Damerham: the favour accorded to Eadgifu appears to be an early expression of the principle observed by Stafford, that 'there could not be two queens in the royal household' ${ }^{404}$ Yet, with the Second Ordo in place by 925 at the latest, it is likely that Edmund's queens had been anointed. Indeed, Edmund had probably married Elfgifu at around the time of his accession, since his second son Edgar was born in 943.405 Given the significance of the Second Ordo in relation to queens, it would be more difficult to account for Eadgifu's special status if she had not also been anointed. This would require the Second Ordo to have been in existence by the later 910s.

One further perspective on queenship concerns the circumstances of Æthelstan's accession. On Edward the Elder's death, Æthelstan's claim appears initially to have been overlooked in favour of that of his younger half-brother Ælfweard, the son of Edward's second wife, Ælfflæd. As Barbara Yorke has observed, the story reported by William of Malmesbury, that Æthelstan's mother, Ecgwynn, had been of low birth and a concubine, may be best regarded as a retrospective slur. ${ }^{406}$ Indeed, as will be explored below, Ecgwynn's marriage to Edward the Elder, contracted $c$. 893, probably had important implications for the succession. ${ }^{407}$ Once the significance of this marriage is appreciated, some sort of explanation is needed for the apparent preference for Ælfweard over his elder half-brother Æthelstan in 924. Both claimants were adult sons - Æthelstan was probably thirty, whereas Ælfweard would have been in his early or mid twenties - but of different mothers. There are possible parallels with the disputed succession after Edgar's death in 975 when, according to a story told by Eadmer, one of the arguments deployed against the claims of Edward the Martyr had been that his parents had not been anointed at the time of his birth, although they had been legally married. ${ }^{408}$ As Nelson has argued, the specific nature of Eadmer's story suggests that it should be taken seriously. 409

403 Æthelweard, Chronicon IV.6 (ed. Campbell, p. 54). ASC 946 D: The Anglo-Saxon Chronicle MS D, ed. G. P. Cubbin, The Anglo-Saxon Chronicle: a Collaborative Edition, ed. D. Dumville and S. Keynes 6 (Cambridge, 1996), 44 (text); Anglo-Saxon Chronicle, ed. Whitelock et al., p. 72 (translation)

404 Stafford, 'The King's Wife in Wessex', p. 18; idem, Queen Emma and Queen Edith, pp. 216-19 and 259-62, cf. 57-64. Cf. S 549 (Burt 8), dated 949, for the possible attestation of Æthelflæd of Damerham during Eadred's reign.

405 P. Stafford, 'Edmund I (920/21-946)', ODNB. Ethelstan died at Gloucester on 27 October 939. The Tiberius A. iii regnal list would imply 29 November as the date of Edmund's coronation: Keynes, 'Church Councils, Royal Assemblies', p. 149.

406 Yorke, 'Edward as Ætheling', p. 33; idem, ‘ Ethelwold and the Politics of the Tenth Century', pp. 69-70, cf. 66-7 Foot, Athelstan, pp. 29-31.

407 See below, pp. 00-00/72-4.

408 Eadmer, Vita S. Dunstani, c. 59, in Eadmer of Canterbury: Lives and Miracles of Saints Oda, Dunstan, and Oswald, ed. A. J. Turner and B. J. Muir (Oxford, 2006), p. 144. Cf. also c. 56 (ed. Turner and Muir, p. 136). Eadmer appears to have written to contacts for information on Edward's parentage: his account relied on a 
One may assume that raw politics played a role in determing the recognition of Ælfweard in 924: Æthelstan's probable upbringing in Mercia may have been a factor, and William of Malmesbury's story about Ecgwynn might have reflected a contemporaneous attitude. Yet account should also be taken of the career of Ælfflæd: her relatively high political profile is indicated from several perspectives. 410 The inclusion of the young Elfweard in the witness-list for an important gathering in 901, in a position above Æthelstan, suggests that the current consort's offspring then had precedence. ${ }^{411}$ Ælfflæd evidently had favourable relations with Frithestan, bishop of Winchester (909-31), since she acted as patron to the stole and maniple produced for Frithestan around the second decade of the tenth century, which subsequently reached Chester-le-Street, possibly by King Æthelstan's gift. ${ }^{412}$ The naming of a consort, by inscription, is an unusual instance of patronage, though the items are rare survivals. ${ }^{413}$ That Frithestan may have been among those initially unwilling to accept Æthelstan's rule, as suggested by the charter record, points to the importance of Ælfflæd's relations with the bishop. 414 Ælfflæd's high standing is also suggested by the international marriages secured for her daughters, including Eadgifu, who married Charles the Straightforward during her father's lifetime. ${ }^{415}$ If the Second Ordo had been first used for Edward's consecration on Whitsunday 900, then this would have had consequences for Ælfflæd: as will be explored below, it seems likely that Ælfflæd would have been anointed as his queen. ${ }^{416}$ The drafting of the Second Ordo late in Alfred's reign might therefore help to explain Ælfflæd's subsequent profile and Ælfweard's claim in 924; whereas if,

letter from Prior Nicholas of Worcester, who had undertaken research on the matter (Memorials of Saint Dunstan, ed. W. Stubbs, RS 63 (London, 1874), 422-4; Turner and Muir, Eadmer of Canterbury, pp. 1xviii and lxxii). Nicholas's letter does not explicitly state that Edward's status had been raised as an issue by those opposing his succession, but might be taken to imply this; Eadmer may possibly have had other reasons for regarding the lack of anointing as part of the case against Edward's claim.

409 J. L. Nelson, 'Inauguration Rituals', in her Politics and Ritual, pp. 283-307, at p. 300; Keynes, Diplomas, p. 165.

410 Stafford, 'The King's Wife in Wessex', p. 25; S. Miller, 'Edward [Edward the Elder] (870s?-924)', ODNB. William of Malmesbury named Ælfflæd's father as Ethelmus comes, probably to be identified as Æthelhelm, ealdorman of Wiltshire, whose death is recorded in the Chronicle for 897. William of Malmesbury, Gesta regum II.126 (ed. Mynors, et al. I, 198); Yorke, 'Æthelwold and the Politics of the Tenth Century', pp. 69-72, at 70 .

411 S 365 and 366 (WinchNM 4 and 5). Keynes, 'Edward, King of the Anglo-Saxons', pp. 50-1.

412 Keynes, Liber Vitae, pp. 18-20; Karkov, Ruler Portraits, pp. 57 and 73-6; Foot, Athelstan, pp. 122-3; E. Coatsworth, 'The Embroideries from the Tomb of St Cuthbert', Edward the Elder, ed. Higham and Hill, pp. 292-306.

413 M. Lapidge, 'Artistic and Literary Patronage in Anglo-Saxon Literature', in his Anglo-Latin Literature 600899 (London, 1996), pp. 37-91, at 51.

414 Keynes, Liber Vitae, pp. 20-1, observing Frithestan's absence from the witness-lists of diplomas early in Æthelstan's reign. See also idem, Atlas, Table XXXVII; Yorke, 'Æthelwold and the Politics of the Tenth Century', pp. 72-3. Frithestan's political alignment has a bearing on the understanding of his probable association with the 'Parker manuscript' of the Anglo-Saxon Chronicle (Cambridge, Corpus Christi College 173 ) in the same period: see Dumville, Wessex and England, pp. 131-4, cf. 86-7.

415 Foot, Athelstan, pp. 44-52; MacLean, 'Cross-Channel Marriage', pp. 30-40.

416 See below, pp. 00-00/72-3. 
hypothetically, the First Ordo had been used in 900, neither Ælfflæd nor Edward's third wife, Eadgifu, would have been anointed at all.

This reasoning has one further implication, in that the anointing of queens seems likely to have boosted the claims of sons arising from any marriage contracted at, or after, the king's accession. This is suggested by the instance of Ælfweard, and would also be implied by the argument reportedly made against Edward the Martyr in 975, that his parents had not been anointed at the time of his birth. ${ }^{417}$ Little is known of Edgar's first wife, Ethelflæd 'the White', also known as Eneda, but the marriage appears to have ended by the early 960s, when Edgar married his second wife, Wulfthryth. ${ }^{418}$ Edward's rival for the throne, Æthelred, had been the son of Edgar's third wife, Ælfthryth, whom Edgar had married in 964 or $965 .{ }^{419}$ The matter of Æthelflæd's status is complicated by the events of 957, when Edgar's brother, King Eadwig, faced the formal division of the kingdom of the English, acknowledging Edgar's authority north of the Thames, and by the lack of evidence for an anointing ceremony for Edgar early in his reign. ${ }^{420}$ A breach of established practice seems unlikely, however, and, partly relying on Eadmer's narrative, Nelson has advanced an intricate argument for suspecting that Edgar had been anointed by Dunstan late in 960 or early in 961.421 On a similar basis, one may strongly suspect that Ælfthryth had been anointed at the time of her

417 'Qui Edwardus cum in regem consecrari deberet, nonnulli de principibus terrae contraire ne rex fieret nisi sunt $[. .$.$] quia matrem eius, licet legaliter nuptam, in regnum tamen non magis quam patrem eius, dum eum$ genuit, sacratam fuisse sciebant' (When this Edward ought to have been consecrated as king, many of the princes of the land sought to oppose that he should become king [...] because they knew that his mother, though legally married, had not been consecrated to the kingdom any more than his father had been, when he begot him'): Eadmer, Vita S. Dunstani, c. 59 (ed. Turner and Muir, p. 144). I have adjusted the translation slightly to accord with Nelson's reading of the passage ('Inauguration Rituals', p. 300).

418 William of Malmesbury, Gesta regum II.159 (ed. Mynors, et al. I, 260). John of Worcester, Chronicon, s.a. 964 (ed. Darlington and McGurk II, 416). B. Yorke, 'The Women in Edgar's Life', Edgar, ed. Scragg, pp. 143-57, at 144-5. Æthelflæd was the daughter of Ordmær, called a dux potentissimus by William. He may be identified as the vir potens Ordmær, who is represented as having bequeathed a large estate at Hatfield, Hertfordshire to King Edgar: Libellus Ethelwoldi episcopi, c. 5 = Liber Eliensis II.7 (Liber Eliensis, ed. E. O. Blake, Camden Third Ser. 92 (London, 1962), 79). Title to the Hatfield estate was subsequently disputed by the sons of Æthelstan 'Half King', who claimed that their father had acquired it from Ordmær in exchange for land in Devon. Ordmær may possibly have been a relative of the south-western ealdorman, Ordgar, the father of Ælfthryth. See C. Hart, 'Athelstan "Half King” and his Family', in his The Danelaw, pp. 569-604, at 586 and 589.

419 ASC 965 DF: Two Chronicles, ed. Plummer I, 119 (text); Anglo-Saxon Chronicle, ed. Whitelock et al., p. 76 (translation). John of Worcester, Chronicon, s.a. 964 (ed. Darlington and McGurk II, 416). Cf. S 725 (Abing 101).

420 S. Keynes, 'Eadwig (c. 940-959)', ODNB; idem, Diplomas, pp. 48-69; idem, 'Edgar, Rex Admirabilis', pp. 7-9 and 13-14; S. Jayakumar, 'Eadwig and Edgar: Politics, Propaganda, Faction', Edgar, ed. Scragg, pp. 83103. Keynes, 'Church Councils, Royal Assemblies', p. 149.

421 Nelson, 'Inauguration Rituals', pp. 298-9, taking account of Dunstan's absence from England in the spring and summer of 960 to collect his pallium from Pope John XII. Dunstan's appointment to Canterbury had involved complications; Nelson's reasoning receives some support from the career of Lyfing, archbishop of Canterbury, who had been appointed by King Æthelred in 1013 (having previously held the see of Wells), but did not obtain his pallium until 1017/18. In the intervening period Lyfing was accorded the title 'bishop' only; Lyfing's lack of the pallium may also explain why Ælfwig, bishop of London, was consecrated at York in 1014. Brooks, Canterbury, p. 288; Pratt, 'Kings and Books', p. 364, n. 345, with references. 
marriage to Edgar, a view supported by her prominence in witness-lists and favourable treatment in the New Minster Refoundation Charter of 966. ${ }^{422}$ Edgar's marriage to Æthelflæd cannot be closely dated, but an early date is suggested by a number of considerations. By the early 960s Edgar had married Wulfthryth and fathered her daughter, Edith; Prior Nicholas of Worcester, who undertook research for Eadmer, also placed Edgar's marriage to Æthelflæd at the beginning of his reign. ${ }^{423}$ Politically, royal marriage was especially sensitive at this time since, following the division of the kingdom, Eadwig's marriage to Ælfgifu had been dissolved by Archbishop Oda in 957 or 958; the context would have created powerful incentives for Edgar to have married, since the prospect of offspring would have consolidated his dynastic position. ${ }^{424}$ It therefore seems quite possible that Edgar married Æthelflæd in the period 957/8 x 960, either during the latter part of his rule over Mercia and Northumbria, or after his accession to the kingdom of the English in October 959.425 If, as seems likely, Edward had been born before Edgar's putative anointing by Dunstan, perhaps late in 960 or early in 961, the circumstances would accord with the argument reported by Eadmer against Edward's subsequent claim to kingship. Hinting at the dynastic significance of queenly anointing, Eadmer's story has a bearing on the Second Ordo. Ethelstan, the son of a marriage contracted before his father's accession, initially lost out in 924 to the claims of a younger half-brother. Given his parentage, and especially in such circumstances, he seems a dynastic member less likely to have presided over the introduction of anointing for queens.

\section{THE SECOND ORDO AND LATE ALFREDIAN POLITICAL STRATEGY}

The case for dating the Second Ordo to the latter part of Alfred's reign has so far depended on two lines of argument: firstly, considerations relating to Alfred's network of crossChannel contacts, which provide the most plausible context for the importation of the Leiden Ordo to England; and, secondly, objections to the possibility of the Second Ordo having been

\footnotetext{
422 S 745 (WinchNM 23), the wtitness-list of which represents Elfthryth's infant son Edmund as 'clito legitmus', followed by Edward as 'clito', and then Ælfthryth as 'legitima [...] coniuncx'. For the use of goldfilled crosses to reinforce the positions of Elfthryth, Edmund and other important witnesses, see Miller, Charters of the New Minster, Winchester, pp. 110-11. For the exceptional nature of Ælfrthyth's presence in witness-lists, see Keynes, 'Edgar, Rex Admirabilis', p. 27; idem, Atlas, Table XXXIc; D. Pratt, 'The Voice of the King in "King Edgar's Establishment of Monasteries"', ASE 41 (2013), 145-204, at 183, n. 204, with references.

423 Memorials of Saint Dunstan, ed. Stubbs, p. 423.

424 ASC 958 D (= 957 or 958): ASC MS D, ed. Cubbin, p. 45 (text); Anglo-Saxon Chronicle, ed. Whitelock et al., p. 74 (translation). Keynes, 'Eadwig (c. 940-959)'; cf. also Yorke, 'Æthelwold and the Politics of the Tenth Century', pp. 77-8.

425 Having been born c. 943, Edgar would have been in his mid to late teens in this period. Cf. Eadwig's early age - about sixteen - at the time of his marriage, which probably took place in 956: S 1292 (Abing 76). It is likely that Eadwig's death had not been anticipated; any marriage for Edgar during Eadwig's lifetime would have had considerable significance.
} 
drafted early in Æthelstan's reign. To these arguments should now be added a final set of considerations: namely, the strong degree of congruity between the content of the Second Ordo and the political and dynastic context late in Alfred's reign. These considerations have particular significance in view of the arguments against a later dating, strongly implying that the drafting of the Second Ordo should be located late in Alfred's reign. Although the argument is conditional, it gains strength from its dependence on a range of mutually reinforcing features of the evidence and the political context. If the argument is accepted, the analysis also offers the possibility of insight into late Alfredian political strategy.

The importing of the Leiden Ordo via Alfred's northern Frankish connections would suggest a dating in the mid or late 890s for the Second Ordo. The close relationship between the Second Ordo and its principal West Frankish sources, Erdmann (c. 880) and Leiden (893), would be consistent with the activities of a compiler working with recently imported material. The message of the Second Ordo, promoting rule over 'Angles' and 'Saxons', would harmonize strikingly with the general context of what one might term 'kingdombuilding': namely, the efforts by Alfred to promote the unity of his rulership over the 'kingdom of the Anglo-Saxons' and to safeguard its future. The earliest signs of the promotion of Alfred's wider rule can be found in his coinage and in the new charter styling, 'king of the Anglo-Saxons', from the early 880s. ${ }^{426}$ Probably of importance were the events of 886, when King Alfred 'occupied' London and received a widespread submission of the peoples under his rule; a subsequent expression was Alfred's law-book, perhaps issued in the later 880s, a major message of which was the fusion of different peoples - West Saxons, Mercians, Kentish - to form a single kingdom. ${ }^{427}$ Another manifestation was the Chronicle itself which, as Keynes has pointed out, took care to acknowledge Mercia's place in the shared history of the English people. ${ }^{428}$ In respect of the new ordo, what should be stressed is the appropriateness of the West Frankish sources for Alfredian political circumstances. The notion of uniting rule over two peoples, already present in the Leiden Ordo, lent itself to Alfred's new form of rule. 'Franks' and 'Aquitanians' could give way to 'Angles' and Saxons'. Also striking is the case for associating Grimbald, by probable influence or involvement, with two 'foundational' documents, namely the law-book and the Second Ordo;

426 Keynes, 'King Alfred and the Mercians', pp. 19-34; idem, 'Alfred the Great and the Kingdom of the AngloSaxons', pp. 22-6.

427 Keynes, 'King Alfred and the Mercians', pp. 21-6 and 40; idem, 'Alfred the Great and the Kingdom of the Anglo-Saxons', pp. 24-5; Pratt, Political Thought, pp. 214-41. esp. 218-22. Asser's final chapter, describing the king's efforts to promote the pursuit of wisdom among his ealdorman, reeves and thegns may be variously interpreted, but the reference to the study of 'justice' (aequitas) through the reading of books in English strongly suggests that the law-book had been in existence by 893: Asser, Vita Alfredi, c. 106 (ed. Stevenson, pp. 93-4; Keynes and Lapidge, Alfred, p. 110). The case for regarding the introduction to the law-book as responding to Fulk's letter to Alfred (c. 886) provides an earlier terminus relevant to the internal content. Whitelock, Councils 871-1066, p. 16; Pratt, Political Thought, pp. 167, 219 and 223-8; cf. Wormald, Making of English Law I, 120-1, 281, 286 and 425-6.

428 Keynes, 'King Alfred and the Mercians', pp. 40-1; idem, 'Alfred the Great and the Kingdom of the AngloSaxons', pp. 34-5. 
these associations strengthen the impression that the pair formed part of a coherent strategy. ${ }^{429}$ In the preliminary promise, the investitures of the sceptre and rod, and the three precepts, the Second Ordo had strong legal dimensions. In the law-book, as Wormald showed, further West Frankish influence may be strongly suspected in the 'treason' legislation, the law of hlafordsearu. ${ }^{430}$ It would not be unreasonable to posit here further glimpses of Grimbald's input.

The context of kingdom-building suggests the importance of the succession for the compiling of a new anointing ritual. The effect is to locate the Second Ordo where Nelson originally placed it, as a feature of the political positioning over the succession in the latter part of Alfred's reign. ${ }^{431}$ For Alfred, as for his predecessors, this was an area of tensions: the surviving version of the king's will, drawn up before June 888, indicates the problematic position of Alfred's two nephews, Æthelwold and Æthelhelm, the sons of Alfred's elder brother, Æthelred, since Alfred favoured the succession of his son, Edward the Elder. ${ }^{432}$ One should highlight the significance of Edward's marriage to his consort, Ecgwynn, contracted sometime in the early $890 \mathrm{~s}$. The marriage may be tentatively dated $c .893$ on the basis of William of Malmesbury's report that Ecgwynn's son, Æthelstan, had been thirty at his accession. ${ }^{433}$ Ecgwynn was later subject to the rumour, reported by William of Malmesbury, that she had been of low birth and merely a concubine to Edward: these claims should be seen in the context of Æthelstan's own problematic succession, however, and William elsewhere describes Ecgwynn as an illustris femina. ${ }^{434}$ As indicated by the circumstances of Alfred's own marriage, the marrying of a royal son during the reign of a ruling king was an important event, having implications for the succession. ${ }^{435}$ It is therefore tempting to regard the Second

429 Keynes, 'Edward, King of the Anglo-Saxons', pp. 48-9 and 58; idem, 'Alfred the Great and the Kingdom of the Anglo-Saxons', p. 40.

430 P. Wormald, 'Frederic William Maitland and the Earliest English Law' and 'Engla Lond: the Making of an Allegiance', in his Legal Culture in the Early Medieval West: Law as Text, Image and Experience (London, 1999), pp. 45-69, at 55-7 and 61-3, and 359-82, at 366-7; idem, Making of English Law I, 144-8 and 283-4; idem, Papers Preparatory to The Making of English Law: King Alfred to the Twelfth Century. II: From God's Law to Common Law, ed. S. Baxter and J. Hudson (London, 2014), 98-191, available online. See also Pratt, Political Thought, pp. 232-41; idem, 'Written Law'.

431 Nelson, 'The Earliest Surviving Royal Ordo', pp. 365-7; idem, ““A King Across the Sea”, p. 56.

432 S 1507 (WinchNM 1); Keynes and Lapidge, Alfred, pp. 173-8.

433 William of Malmesbury, Gesta regum II.133 (ed. Mynors, et al. I, 210). Yorke, 'Edward as Ætheling', p. 26.

434 William of Malmesbury, Gesta regum II.131 and 139, cf. II.126 (ed. Mynors, et al. I, 206 and 224-6, cf. 198); Yorke, 'Edward as Ætheling', p. 33, with references; Foot, AEthelstan, pp. 29-31.

435 As revealed by the terms of king's will, Alfred's marriage in 868 prompted a renegotiation between Alfred and his elder brother Æthelred over the joint inheritance of bookland, which had previously represented the personal property of King Æthelwulf. The resulting agreement, reached at an assembly at Swinbeorg, in determining that the joint property would pass to whichever brother lived the longest (with compensatory arrangements for the children of the the brother who died first), appears to have confirmed the expectation that Alfred would succeed, provided that he outlived Æthelred. As such, it lends substance to Asser's report that Alfred had been regarded as the likely or designated heir at the time of his marriage: Asser, Vita Alfredi, c. 29 (ed. Stevenson, p. 23-4; Keynes and Lapidge, Alfred, p. 77). See esp. A. Williams, 'Some Notes and Considerations on Problems Connected with the English Royal Succession, 860-1066', ANS 1 (1979), 144-67 and 225-33, at 145-8; Keynes and Lapidge, Alfred, pp. 15-16 and 314-16; cf. Nelson, 'Reconstructing a Royal 
Ordo as postdating Edward's marriage to Ecgwynn, and as having been shaped by its consequences. In the event, by 901 Edward had married his second wife, Ælfflæd: since her young son, Ælfweard, was listed as attending an important gathering at Southampton in 901, it seems likely to have been Ælfflæd who was anointed on the occasion of Edward's coronation on Whitsunday (8 June) 900.436 The timing of Edward's second marriage is uncertain, but it seems more likely to have postdated, rather than preceded, Alfred's death. Although one might possibly envisage a context for the compiling of the Second Ordo in connection with Edward's second marriage, dynastic and chronological considerations would fit better with the consequences of his earlier marriage to Ecgwynn.

A further possible indication of Alfred's intentions is provided by the story, reported by William of Malmesbury, that Alfred had invested the young Æthelstan with a cloak, sword and belt. ${ }^{437}$ The event, by implication occurring in the later 890 s, has been plausibly connected by Michael Lapidge with the acrostic poem, bearing the legends ADALSTAN/IOHANNES, probably composed by John the Old Saxon. ${ }^{438}$ As Lapidge has argued, the key evidence for such a connection is the poet's word 'triumuir', probably meaning consul: parallels with the investiture of Alfred with the insignia of a consul by Pope Leo IV in 853 would suggest a ceremony designed to promote Æthelstan's throneworthiness, possibly modelled on the earlier event. ${ }^{439}$ The suggestion that Æthelstan's investiture represented a scheme to bypass Edward's claim in favour of Æthelstan seems unlikely given the latter's young age, probably no more than five on Alfred's death. ${ }^{440}$ The more likely interpretation, strengthened by the report that Alfred had arranged for Æthelstan to be reared in Mercia in the care of Æthelflæd and her husband, ealdorman Æthelred, is that Æthelstan's investiture reflected long-term planning by Alfred for Æthelstan's future succession. ${ }^{441}$

Family', pp. 62-3. Edward's elevated status may possibly be indicated by his attestation as 'rex' in S 350 (CantCC 99), dated 898, which survives as an apparent original: ibid., p. 65; Yorke, 'Edward as Ætheling', p. 32; Keynes, 'King Alfred and the Mercians', p. 36, n. 154; Miller, 'Edward [Edward the Elder] (870s?-924)'.

436 S 365 and 366 (WinchNM 4 and 5). Keynes, 'Edward, King of the Anglo-Saxons', pp. 50-1; Miller, 'Edward [Edward the Elder] (870s?-924)'.

437 William of Malmesbury, Gesta regum II.133 (ed. Mynors, et al. I, 210).

438 M. Lapidge, 'Some Latin Poems as Evidence for the Reign of Athelstan', in his Anglo-Latin Literature 9001066 (London, 1993), pp. 49-86, at 60-9. Cf. the proposed reinterpretation by G. R. Wieland, 'A New Look at the Poem "Archalis clamare triumuir", Insignis sophiae arcator: Medieval Latin Studies in honour of Michael Herren, ed. R. R. Wieland, C. Ruff and R. G. Arthur (Turnhout, 2006), pp. 178-92, discussed by Foot, Athelstan, pp. 32-3 and 110-12. As Wieland implies, the reference to 'holy eminence of learning' might need to be read figuratively if praising a young child (pp. 179-80); Wieland's alternative hypothesis, that the poem had been written for Æthelstan in adulthood, c. 924 (pp. 188-92), takes insufficient account of the prophetic context inherent in the reference to Samuel (cf. I Kings VII-VIII), Æthelstan's dynastic significance as the son of Ecgwynn, and the similarity to two other acrostics written in King Alfred's lifetime.

439 Lapidge, 'Some Latin Poems', pp. 60-1 and 67-9. For Alfred's investiture, see Keynes, 'Anglo-Saxon Entries', pp. 112-13.

440 The idea is floated by Nelson, 'Reconstructing a Royal Family', pp. 63-4.

441 William of Malmesbury, Gesta regum II.133 (ed. Mynors, et al. I, 210); Yorke, 'Edward as Ætheling', p. 29. William's report is uncorroborated, but his extended account of Æthelstan's life appears to have been based in part upon local tradition. The entrusting of a royal son to an elite family has parallels in the upbringing of 
Together with Edward's marriage to Ecgwynn, the investiture implies the consistent intention on Alfred's part of passing on the 'kingdom of the Anglo-Saxons' intact. Despite Æthelwold's ill-fated bid for the throne, this aim would be subsequently realized on Edward's accession. ${ }^{442}$

The Second Ordo fits well with this dynastic dimension of kingdom-building. The message of the unity of two peoples and paternal succession, all borrowed from the Leiden Ordo, articulated Alfredian intentions for the kingdom and the dynasty. The added phrase, expressing the hope that the newly anointed king might 'establish and govern the apex of paternal glory unitedly', would appear to be invoking Alfred's political legacy. ${ }^{443}$ More generally, the new ordo updated the regalia, bringing these in line with wider Carolingian practice. The addition of a preliminary promise, of Hincmarian derivation, would be appropriate in the context of the borrowing of legal principles from Rheims, while the incorporating of the idea of episcopal mediation of the royal office may have been aided by the existing English practices of episcopal profession. ${ }^{444}$ The promise did not introduce a formal, conditional element to king-making, but was presented as a necessary preliminary to the ritual of anointing. The promise, to preserve 'canonical privilege and due law and justice' for bishops and churches, would have amounted to a firm statement in an English context. ${ }^{445}$ The First Ordo had lacked any expression of special royal responsibilities towards the church or bishops. ${ }^{446}$ It is likely that the holding of synods in the province of Canterbury ceased in the second half of the ninth century; indeed, the English were regularly criticized in papal correspondence of the ninth century on matters of sexual laxity in terms implying a neglect of canon law. ${ }^{447}$ These criticisms should be taken seriously as a form of external comment, though it is very difficult to assess the realities of English ecclesiastical discipline. Significantly, nevertheless, Fulk had represented Grimbald's recruitment as a means of securing English observance of the 'holy canons'. ${ }^{448}$ The inclusion of the promise might

Edgar and of the Atheling Æthelstan, the eldest son of Æthelred II: Hart, “Athelstan "Half King”, pp. 579-80, 586 and 589; Stafford, 'The King's Wife in Wessex', p. 21, n. 58. See also Karkov, Ruler Portraits, pp. 77-9; Foot, Athelstan, pp. 33-4, cf. 11-12. It is tempting to envisage a connection with the ending of Edward's marriage to Ecgwynn (by whatever means), but one should be alive to other possibilities; William represented the development as a mark of favour for Æthelstan, attributing the initiative to King Alfred.

442 Keynes, 'King Alfred and the Mercians', pp. 36-8; idem, 'Edward, King of the Anglo-Saxons'.

443 Sacramentary of Ratoldus, ed. Orchard, p. 49.

444 See above, p. 00/11, n. 62.

445 Sacramentary of Ratoldus, ed. Orchard, pp. 47-8.

446 See above, pp. 00-00/14-15.

447 Pratt, Political Thought, pp. 48, 50-2 and 211-12; Nelson, “"A King Across the Sea”, pp. 45-7 and 61-2.

448 Councils 871-1066, pp. 9-10, cf. 11, where Fulk himself invokes the Hincmarian mechanism of a professio to describe the actions of those who were to accompany Grimbald back to England: 'profiteantur atque promittant, eum condigno honore se habituros omni tempore vitae suae; necnon decreta canonica, et sanctiones ecclesiasticas ab apostolis et apostolicis viris ecclesiae traditas, quae tunc a nobis audire et videre, et postea ab eodem suo pastore et doctore secundum formam a nobis sibi traditam discere potuerint, cunctis diebus inrefragabiliter velle custodire' ('They are to profess and promise aloud to me in the presence of all my church that they will accept him with appropriate honour all the days of his life, and that they have the 
therefore make sense in the context of Grimbald's mission, as Fulk had described it. As I have argued elsewhere, there are grounds for detecting engagement between Fulk's letter to Alfred and the introduction to Alfred's law-book, on the subject of divine law: the introduction hints at a subtle defence of English legal practices informed by Fulk's criticisms. ${ }^{449}$ The law-book and the Second Ordo here again bear comparison, as forms of response to Fulk's ambitious agenda.

The other major change represented by the Second Ordo, the addition of a queen's ordo, would also fit well with a late Alfredian context. The anointing of queens, departing from the practice implied by the First Ordo, would have had a clear and potent context in Edward's married status, and in the concern expressed by Asser at the low status of the 'king's wife'. ${ }^{450}$ The change was a further regularization in line with Carolingian practice: politically, the anointing of queens had the potential to imply a narrowing of the dynastic line, since it created a distinction between consorts who had been anointed and those who had not. ${ }^{451}$ This accords well with the treatment of Edward and the young Æthelstan in the latter part of Alfred's reign: both Edward's marriage and Æthelstan's subsequent investiture reinforced the centrality of Alfred's line, at the expense of his two nephews. It therefore seems likely that a strategic change in West Saxon kingship, in favour of the anointing of queens, arose out of Alfredian plans for the succession. In the event, Edward was duly anointed on Whitsunday 900, in all likelihood as 'king of the Anglo-Saxons'. The later report, that Edward had been anointed at Kingston, deserves respect. ${ }^{452}$ The regular use of Kingston for royal anointings in the tenth century indicates that the site had significance. ${ }^{453}$ Uncertainties over the location of ninth-century anointings hinder the assessment, but it is difficult not to see some connection with the earlier Kingston agreement (838) between Ecgberht, Ethelwulf and Canterbury. ${ }^{454}$ As a royal vill on the Thames, in the eastern regions rather than the heartlands of Wessex, the location appears geographically appropriate to the broader rule of Alfred and his successors. As Keynes has implied, it is possible that Kingston's role in respect of anointing began with Edward, thus having Alfredian origins intertwined with the making of the 'kingdom of the Anglo-Saxons'. ${ }^{455}$

\footnotetext{
intention of maintaining unalterably all their days the canonical decrees and ecclesiastical injunctions handed down by the apostles and other apostolic men of the church, which they can now hear and observe from me, and afterwards can learn from their pastor and teacher in the form handed down by us'). Cf. the forms of collective undertaking at West Frankish royal assemblies highlighted by Nelson, 'Kingship, Law and Liturgy', pp. 147-9.

449 Pratt, Political Thought, pp. 223-30. See above, p. 00/71, n. 427.

450 See above, pp. 00-00/13-14.

451 Stafford, 'The King's Wife in Wessex', pp. 16-18.

452 Ralph de Diceto, Abbreviationes Chronicorum, s.a. 900 (The Historical Works of Master Ralph de Diceto,

Dean of London, ed. W. Stubbs, 2 vols., RS 68 (London, 1876) I, 140; Keynes, 'The Burial of King

Æthelred', pp. 132-3. Cf. Nelson, 'The First Use of the Second Anglo-Saxon Ordo', p. 122, n. 27.

453 Keynes, 'Church Councils, Royal Assemblies', pp. 149-50.

454 Pratt, Political Thought, pp. 74-5, with references. See above, pp. 00-00/11-12.

455 Keynes, 'Edward, King of the Anglo-Saxons', p. 48.
} 


\section{CONCLUSIONS}

The relating of a royal ordo to specific historical circumstances is a difficult form of argument with inherent uncertainties. The circulation of ordines as an evolving form of liturgical text, and their preservation within pontificals, ensures that the study of ordines has to be conducted in awareness of the degree of distance that separates transmitted texts from individual instances of anointing. Even in the case of texts which appear to imply specific details of the circumstances in which an anointing may have been conducted, the analysis leads to arguments concerning the likelihood of a rite being employed on a particular occasion. Here one must hope for a degree of cumulative weight arising from multiple forms of historical consideration. For Anglo-Saxon ordines, the limited attention to coronations in narrative sources presents a further hindrance. To some extent, nevertheless, this is offset by certain features of the ordines: namely, their inter-relationship as a sequence of texts; the references to peoples and territories under the king's rule; and the relationship of the Second Ordo to its sources.

This article has shown the significance of the final feature. The character of the anointing prayer, which originally invoked rule over 'Angles' and 'Saxons', yields 880 x 925 as outer limits. Yet the understanding is transformed once it is appreciated that the Second Ordo relied on two West Frankish sources, whose context can be determined: the Erdmann Ordo (c. 880) and, rather than the Ordo of Seven Forms, the Leiden Ordo. The Second Ordo may thus be excavated through a form of 'textual archaeology', casting light on the original process of compilation. The Leiden Ordo provided many elements of the anointing prayer, including the references to kingship over two peoples: previously regarded as the result of English editorial intervention, the idea must be seen as one imported from this West Frankish source. Leiden also represented the king's circumstances as those of a son acceding to his father's throne, with his father having died. These circumstances, together with the rule claimed over 'Franks' and 'Aquitanians', would be matched only by the anointing of Charles the Straightforward by Fulk of Rheims on 28 January 893.

The importing of West Frankish ordines into England has long been inferred from the Second Ordo, but once the likely origin of Leiden is recognized, the received view must be revised. The two principal sources had been in existence by early 893; of particular importance are the circumstances of the mid to late 890 s which provide the most plausible context for importation of these sources to England, and one which might help to explain the combining of Erdmann and Leiden. These circumstances comprise the role of Grimbald of StBertin in King Alfred's service; Alfred's contact with Fulk of Rheims, and probable contact with Rodulf, abbot of St-Bertin, over Grimbald's recruitment; the marriage of Alfred's 
daughter, Ælfthryth, to his step-brother, Baldwin II, count of Flanders; the struggle on both sides of the Channel against viking armies, including those contingents which invaded England in 892; the Alfredian evidence for interest in West Frankish politics and the anointing of kings; and Asser's probable awareness of Charles the Straightforward's anointing. The importing of Erdmann and Leiden might be explained as the most recent representatives of West Frankish practice, conveying Sens usage and the rite used for Charles. Within Alfred's network of northern Frankish contacts, Grimbald may be regarded as the most economical conduit for the importing of the Leiden Ordo.

Although the putative importing of West Frankish ordines late in Alfred's reign has a number of attractions, the argument here appeals to a balance of probabilities. The case for regarding the Second Ordo as Alfredian also depends on several objections to the possibility of a later scenario early in Æthelstan's reign. The evidence of coinage can provide only a terminus ante quem for the adoption of a royal crown, and would be compatible with an Alfredian date for this development. A gap between 893, the date of the latest source for the Second Ordo, and putative compilation in 924 x 925, would make the interest in Leiden harder to explain. A hypothetical project to promote 'Anglo-Saxon' kingship early in Æthelstan's reign also seems less likely. The principal expressions of the new kingdom had been articulated under Alfred; by Æthelstan's accession the 'kingdom of the Anglo-Saxons' had been in place for a generation and a half. Arguments in favour of 924 x 925 have relied on some sort of division of the kingdom on Edward's death, but it is far from clear that Ælfweard and Æthelstan had briefly ruled Wessex and Mercia discretely.

Further problems with the scenario of compilation for Æthelstan concern queenship. The adding of a queen's ordo was an action of significance, but such a manoeuvre would have no clear motive early in Æthelstan's reign. Æthelstan appears to have remained unmarried; no queen would have been anointed in 925, yet some active editing was involved in the borrowing of the queen's ordo from Erdmann to form the Second Ordo. From the time of the compilation of the Second $\mathrm{Ordo}$, it seems likely that queens were routinely anointed along with their husbands, or on the occasion of their marriage if necessary; such a practice probably contributed to the broader rise in the status of queens in the tenth century. Yet, if the Second Ordo had been drafted for Æthelstan, this would be difficult to reconcile with the career of Edward the Elder's third wife, Eadgifu. Her prominence in charter witness-lists during the reign of Edmund (939-46) came at the expense of Edmund's wives, Ælfgifu and Æthelflæd of Damerham, who seem likely to have been anointed. Account should also be taken of the preference shown to Ælfweard over Æthelstan in 924, and the relatively high political profile of Ælfweard's mother, Edward's second wife, Ælfflæd. Edward's marriage to Æthelstan's mother, Ecgwynn, c. 893, had probably been significant; the likelihood that Ælfflæd had been anointed might help to explain the initial overlooking of Æthelstan in 924. Eadmer's story about the argument used against Edward the Martyr in 975, that his parents 
had not been anointed at the time of his birth, hints at the dynastic significance of queenly anointing, boosting the claims of sons arising from any marriage contracted at or after the king's accession. As the son of a marriage contracted before his father's accession, Æthelstan seems less likely to have initiated queenly anointing.

In addition to the problems posed by a later dating, the case for regarding the Second Ordo as Alfredian depends on the strong degree of congruity between its content and political and dynastic circumstances late in Alfred's reign. The combination of considerations in favour of an Alfredian dating with those against a later context strongly imply that the Second Ordo should be placed late in Alfred's reign. The adaptation of Leiden to express rule over 'Angles' and 'Saxons' would be consistent with the Alfredian strategy of kingdom-building, namely, efforts to promote Alfred's rule over the 'kingdom of the Anglo-Saxons'. The unity of the kingdom was intensively expressed, initially in coinage and the king's styling in charters from the early 880s, then in the submission of 886 and the law-book. In the early 890s, the Chronicle further articulated Alfred's 'Anglo-Saxon' rule. Dynastically, the message of the Second Ordo, emphasizing paternal succession and the unity of an inherited kingdom, would engage with political realities in Alfred's final decade. Of central importance was Edward's marriage to Ecgwynn, c. 893, reinforcing the claims of Alfred's son over his nephews Æthelwold and Æthelhelm. Alfred's investiture of Æthelstan in the later 890s suggests that intentions extended to the future succession of his grandson. The inclusion of a queen's ordo would have clear force in Edward's married status, reflecting the concern at the treatment of consorts and bolstering Alfred's direct line. In view of Grimbald's known expertise in liturgy and ecclesiastical law, one may suspect his involvement in compiling the Second Ordo. There is, additionally, a good case for suspecting Grimbald's influence or involvement in the introduction to law-book, on which basis one might associate Grimbald with two 'foundational' documents relating to Alfred's new kingdom. The possible parallels between the handling of law and liturgy suggest a coherent strategy. The adding of the king's preliminary promise to the anointing rite, a firm statement of responsibilities towards the church, might be understood in the light of Fulk's hopes for Grimbald's mission to England.

The case for regarding the Second Ordo as Alfredian thus depends on the singular appropriateness of the political context late in Alfred's reign, as judged against the difficulties raised by a later dating. Although the argument is conditional, it draws strength from the combination of considerations arising from several perspectives. Finally, one may offer some reflections dependent on the acceptance of the argument. On thought and action at the court of King Alfred, one gains an enriched sense of the promoting of political unity late in the reign. The bolstering of Alfred's kingdom involved not only the submission of 886 and the law-book, but a new and inventive royal ordo. The emphasis on paternal succession supported the dynastic planning necessary for the kingdom to endure. The Second Ordo established new ritual and legal foundations for the kingdom, focused on kingship as an 
institution and as the organizing ideological principle. The development reinforces the value to King Alfred of his Continental contacts and scholarly assistants. Even the identity of Alfred's new kingdom bore the imprint of external influences. The formulation Angli Saxones had probably been borrowed from Continental usage; the dependence of the Second Ordo on Leiden shows that even the ritual statement of kingship over two peoples had been borrowed from a West Frankish rite. One also gains an enhanced sense of Grimbald's value to King Alfred in the area of royal ritual. The argument has implications for the introduction to the law-book, where there are good grounds for suspecting Grimbald's input or influence, in relation to legal theory associated with Rheims and with Grimbald's patron, Fulk. The present view of the Second Ordo would thus envisage Grimbald as the mediator of ideas, associated with Rheims and Fulk, which influenced two 'foundational' documents, the law-book and the Second Ordo. The argument reinforces the importance of Fulk for the understanding of Alfredian intellectual concerns.

The use of Leiden in the Second Ordo suggests the significance of the anointing of Charles the Straightforward in 893 for the Alfredian view of West Frankish politics. The view may have arisen from Alfredian knowledge of Fulk's faction and from sympathy for the young Charles, but it probably also reflected a deeper awareness of the possibilities that Charles's brief rule had opened up: namely, the re-establishment of the legitimate male line of the Carolingian dynasty. Central here was the deposition and death of Charles the Fat in 887, highlighted in Asser's narrative, and the representation of Alfred's achievements in complex engagement with Einhard's Charlemagne. The use of Leiden suggests that the view may also have found expression in the new ordo. After 887, both Alfred and Charles might realistically have laid claim to aspects of Charlemagne's legacy. It is therefore significant that the new ordo drew extensively on imported liturgical sources, amounting to the wholesale incorporation of West Frankish practices, of Hincmarian origin or inspiration, mediated through Sens and Fulk of Rheims. The form of cultural contact bears comparison with other West Frankish influences on Alfredian political thinking, particularly evident in the Solomonic language of wealth and wisdom, the inclusion of the Regula pastoralis in the royal programme of translation, the idea of the 'three orders', and in the law-book. ${ }^{456}$ The new view of the Second Ordo allows one to observe the Alfredian deployment, to a striking degree, of Hincmar's position on episcopal authority in the anointing of kings. The episcopal petition and royal promise articulated directly Hincmar's view of the special responsibilities of bishops, as mediators before God of the royal office; the message was reinforced by Sta et retine, taken from Leiden. It is an interesting question how far the new rite was seen to complement the wider languages of office-holding in Alfredian learning, which tended not to assign bishops specific responsibility for kingship or royal conduct. ${ }^{457}$ The links with

456 Pratt, Political Thought, pp. 143-66, 222-38, 277-95 and 340-1.

${ }^{457}$ Ibid., pp. 146-8, 151-66, 202-3, 211-13, 244-5 and 340-1, cf. 58-62, 133-4. 
dynastic strategy suggest that the Second Ordo had Alfred's approval; it is also clear that Fulk had ambitious hopes for Grimbald's future role in England. It may be that such theoretical statements on episcopal authority and duties were seen to be appropriate in the context of the anointing rite, which had the overall purpose of strengthening and exalting the royal office. Through the influence of Erdmann and Leiden, the English sequence of ordines became a conduit for Hincmarian theory on the responsibilities of anointed kings. Yet the existing rite was by no means subsumed; incorporating much of the First Ordo, the Second Ordo amounted to the sensitive fusing of two traditions.

Connecting several aspects of change was the inclusion of a queen's ordo: the anointing of queens reinforced Alfredian plans for the succession, drawing on a queen's ordo of West Frankish origin, derived from Erdmann. The assigning of the Second Ordo to the mid or late 890 s thus has broader implications for queenship, suggesting that the period may have been decisive in the move away from the position of 'king's wife', towards the higher status enjoyed by a number of tenth-century consorts. 458 The shift appears to have been connected with dynastic planning in the 890s, with the intention of strengthening Alfred's line. Such a change would not have been implemented without broader consideration of the likely political effects. With the dynasty of Ecgberht fully entrenched, there may have been attractions in raising the status of consorts; the anointing of queens implied a narrowing of the dynastic line, and, in the context of an expanding kingdom, may have helped to seal strategic marriages with regional aristocratic families. ${ }^{459}$ In the longer term, to judge from the troubled accessions of Æthelstan and Edward the Martyr, the practice of queenly anointing appears to have favoured the claims of sons born to anointed kings, and as such may have had implications for the timing of royal marriages. Both Alfred and Edward had married during their predecessors' lifetimes, reinforcing their claims to succeed; yet there is no certain instance of the same practice in the tenth century, the main possibility relating to the complex politics of the later $950 \mathrm{~s} .{ }^{460}$ Even if one allows for the relative youth of several kings, this feature seems significant. Since marriage during the lifetime of a predecessor had previously represented an important political mechanism, one may suspect that the anointing of queens had broader implications for dynastic strategy. Decision-making over the marriage of a likely claimant would typically be deferred until the succession was confirmed.

For royal ordines, the identification of the Leiden Ordo has the effect of expanding the already significant contribution of ninth-century Rheims. Anointing practices were themselves implicated in the post- 888 'crisis of authority' described by Airlie and MacLean,

\footnotetext{
458 Stafford, 'The King's Wife in Wessex', pp. 4-6, 15-18 and 20-7; idem, Queen Emma and Queen Edith, pp. 57-64, 165-9 and 197-206.

459 Stafford, 'The King's Wife in Wessex', pp. 15-16 and 25; idem, Queen Emma and Queen Edith, pp. 62-3, 66-72 and 82-94.

460 See above, pp. 00-00/69-70.
} 
arising from a shortage of legitimate members of the Carolingian dynasty. ${ }^{461}$ Through the appeal to enthronement and 'hereditary right', Fulk found a means of combining Hincmar's machinery of episcopal mediation with the requirement of dynastic legitimacy, uniquely fulfilled by Charles. Sta et retine, seen by Ullmann as a statement of clerical authority, in context acted as a form of episcopal recognition, the symbolic strengthening of Charles's dynastically transmitted right to rule. ${ }^{462}$ Furthermore, Leiden exerted strong influence on western European ordines, acting as the source for several elements which would become widespread: namely, the idea of kingship over multiple peoples and occupying the paternal throne; the crown formula expressing royal participation in the episcopal ministerium; the uirga as symbol of virtue and equity; and Sta et retine itself. Part of the attraction of Leiden may have lain in the hereditary component, well suited to Alfredian circumstances and to the politics of the age. The dynastic significance of West Frankish anointing intensified in the later tenth century with the practice of associating a royal son in kingship during the lifetime of his father, begun under Lothar with the anointing of his young son Louis in 979.463 The notion of paternal succession would have applied singularly to Louis 'd'Outremer' if, as seems likely, the full Ordo of Seven Forms had been used for his anointing in $936 .{ }^{464}$ Perhaps via the connections of Louis's queen, Gerberga, the Ordo of Seven Forms was incorporated into the full German Ordo, as represented in the Romano-Germanic Pontifical: Sta et retine equally served dynastic rule in Germany. ${ }^{465}$ Although Seven Forms has long been regarded as West Frankish, the identification of Leiden is significant in indicating a specifically Fulkian origin for elements of the full German Ordo. The legacy of Rheims may thus be detected in the four most influential traditions, West Frankish, English, German and Burgundian.

The century after 893 was central to Leiden's subsequent influence. In large measure, this reflected moves towards the regularization of the royal rite in different regions, including the harmonizing of regalia. 466 What may have been encouraging such processes warrants further thought. While it might be tempting to posit the spread of a more homogeneous

\footnotetext{
461 See Bobrycki, 'The Royal Consecration Ordines', pp. 136-7. Airlie, 'The Nearly Men'; idem, “'Sad Stories of the Death of Kings"; idem, 'Les élites en 888 et après'; MacLean, 'The Carolingian Response', pp. 44-8; 'Cross-Channel Marriage', esp. pp. 39-40. See also Schneidmüller, Karolingische Tradition, pp. 9-13, 80-92 and 120-7. In an East Frankish context, the noted refusal of unction by Henry I in 919 may also be understood in dynastic terms: T. Reuter, 'The Ottonians and Carolingian Tradition', in his Medieval Polities and Modern Mentalities, ed. J. L. Nelson (Cambridge, 2006), pp. 268-83, at p. 274; K. Leyser, 'The Ottonians and Wessex', in his Communications and Power in Medieval Europe: the Carolingian and Ottonian Centuries, ed. T. Reuter (London, 1994), pp. 73-104, at p. 86. For a different interpretation, nonetheless framed by the issue of post-Carolingian dynastic legitimacy, cf. S. Bobbie, 'Can Silence Speak Volumes? Widukind's Res Gestae Saxonicae and the Coronation of Otto I Reconsidered', EME 20 (2012), 333-62, at 351-8.

462 W. Ullmann, Principles of Government and Politics in the Middle Ages, 4th ed. (1978), 142-3; idem, The Carolingian Renaissance, pp. 107-9. Cf. Nelson, 'Ritual and Reality', pp. 334-5.

463 For this and later instances of the practice, see Bautier, 'Sacres et couronnements', pp. 51-6.

464 As noted by Schneidmüller, Karolingische Tradition, pp. 149-50.

465 For the full German Ordo, see above, p. 00/25, n. 169.

466 For relevant observations, see Bouman, Sacring and Crowning, pp. 85-9 and 152.
} 
'royal' culture from a Carolingian core, the inter-relationship of ordines was more complex, and the rise of the pontifical as a form of liturgical book presents an important, and partially independent, variable. ${ }^{467}$ As collections containing a number of investiture formulas, Leiden and Seven Forms were well placed to supplement a pre-existing rite. ${ }^{468}$ The subsequent Continental influence of the Second Ordo also played a role, possibly explicable in terms of the blending of Erdmann with Leiden, the practices of Sens with Rheims. The combination had a liturgical rationale but made less sense politically and may have been less likely to have arisen in West Francia. ${ }^{469}$ By the later tenth century, a petition and promise, a sequence of investitures and a formula for enthronement had become more or less standard elements in western ordines, their presence in the English sequence a direct consequence of the Second Ordo. ${ }^{470}$ The First Ordo might have suggested an alternative path of development for the English rite, yet the outcome was a more complex fusion of English and West Frankish elements. Of the additions, the royal promise represented the most significant watershed, providing the basis for the three-fold promise which would prove central to later recensions. ${ }^{471}$ Despite the adjustments associated with the B-version of the mid tenth century, the influence of the Second Ordo on the Third and Fourth Recensions in the central and later middle ages contributed to the relative long-term stability of the English rite. ${ }^{472}$

The compilation of the Second Ordo therefore amounted to a formative instance of liturgical and ideological interchange. In its impact on the English rite, and its subsequent transmission in France, the Second Ordo had longer-term consequences. This reinforces the significance of the late Alfredian context in which, in all likelihood, the Second Ordo should be situated. Securing the future of Alfred's kingdom required a new collective identity, but also dynastic planning. Perhaps more than any other form of royal communication, ritual could connect these two facets of strategy. Part of the attraction of a new anointing rite may have lain in its ability to mold both kingdom and dynasty, countering political uncertainties late in Alfred's reign. As I have argued elsewhere, Alfred's law-book and his programme of translation contributed to a long-term vision, encouraging attitudes to power and wealth congruent with the politics of viking defence. ${ }^{473}$ Attention to the Second Ordo extends the picture of the purposeful use of learned kingship under Alfred, actively responding to Frankish political ideas for discernible objectives. Significantly, it reveals a concern for the

467 Ibid., pp. 73, 80-2 and 85-6. For the pontifical, see above, p. 00/7, n. 38. One should note the consistency with which the B-version of the Second Ordo is attested in late Anglo-Saxon pontificals, although royal ordines may have presented a special case. The evidence is laid out in the Appendix: see below, pp. 00-00/857.

468 Bouman, Sacring and Crowning, pp. 86-9 and 132-5.

469 The A-version of the Second Ordo first appears to have informed the rite used for French kings in the twelfth century: Jackson, Ordines, pp. 30 and 172.

470 Ibid., pp. 87-9.

${ }^{471}$ For the three-fold promise, see above, pp. 00-00/15-16.

472 For the subsequent development of the coronation liturgy, see above, p. 00/2.

473 Pratt, Political Thought, esp. pp. 166-76. 
notion of queenship, generally under-represented in other Alfredian sources; it also highlights the importance of Grimbald, and, behind him, Fulk of Rheims, for the understanding of Alfredian perspectives. From Fulk's perspective, Grimbald represented a spiritual 'watchdog', a means by which England might benefit from the superior canonical observance of the see of Rheims. ${ }^{474}$ Doubtless Grimbald's usefulness would have been regarded differently in some quarters; his role in England was in any case shaped by forces internal to Alfred's household, his kingdom and the Southumbrian church. Nevertheless, in the Second Ordo, drawing on a rite probably used by Fulk, there is strong evidence that in royal ritual, as in other scholarly matters, Alfred and his kingdom had indeed learned from the expertise of Rheims. ${ }^{475}$

\section{Appendix}

\section{TABLE 1: THE TRANSMISSION OF OMNIPOTENS SEMPITERNE DEUS IN MANUSCRIPTS OF THE SECOND ORDO}

The anointing prayer of the Second Ordo, Omnipotens sempiterne deus, is central to the understanding of the rite's relationship to political circumstances, its subsequent revision and transmission. The prayer survives in three main versions: that of the Sacamentary of Ratold, which accorded the king rule over 'Albion'; that of 'SMN' manuscripts, referring to 'the royal throne namely the sceptres of the Saxon, Mercians and Northumbrians'; and the main B-version of the Second Ordo, which implied a king ruling over 'Angles' and/or 'Saxons'. The table below lays out the evidence for the development and transmission of the prayer, which hinges on four readings in the opening section. ${ }^{476}$ As Nelson showed, certain features of the Ratold and 'SMN' texts imply that the A-version had originally applied to a king ruling over two peoples, whose identities are likely to be preserved in manuscripts of the B-version, namely, 'Angles' and 'Saxons'. ${ }^{477}$ As discussed above, it is unclear whether the Ratold and 'SMN' texts represent two discrete versions of the Ordo, since they might also be interpreted

\footnotetext{
474 Councils 871-1066, p. 10.

475 An early version of this article was delivered at a meeting of the Maitland Historical Society, Downing College, Cambridge, 2 February 2016. I am extremely grateful to George Garnett, Simon Keynes, Janet Nelson, Rory Naismith and Tessa Webber for comments and discussion; to David Dumville and Tessa Webber for advice on certain palaeographical matters; and to Simon Keynes for kindly permitting me to take account of unpublished material, as acknowledged in the following footnote.

476 I am most grateful to Simon Keynes for generously sharing with me a stemma originally assembled by him in the 1980s, upon which the table builds in silent dialogue.

477 Nelson, 'The Second English Ordo', pp. 364-5.
} 
as descending from a common English archetype, in which references to 'Albion' and to 'Saxons, Mercians and Northumbrians' had been combined. 478 It should be noted that, elsewhere in the Ordo, 'SMN' manuscripts have readings which are closer than Ratold to the rite's probable sources, suggesting the preservation of an earlier layer of textual development. Two possible reconstructions are therefore outlined: each has strengths and weaknesses, but the second would relate more closely to the charter record, and might on balance be preferred. 479 On either reconstruction, the analysis reinforces Nelson's view of the original form of the prayer. It should also be noted that the readings in question show no interference in the later transmission from related Continental versions of the prayer: namely, the respective anointing prayers in Erdmann, Leiden and Seven Forms (the latter prayer also transmitted via the full German $O r d o$ ). That the Ratold and 'SMN' texts are preserved only in Continental manuscripts is striking. At some level this feature suggests the dominant position of the B-version in England in the later tenth and early eleventh centuries; the record may also reflect the rise of the pontifical as a form of liturgical book, and levels of manuscript survival.

Paris, Bibliothèque nationale de France, lat. 12052 ('Sacramentary of Ratold': northern Francia, s. $x^{\text {ex }}$, before 986). Base text of the A-version (Sacramentary of Ratoldus, ed. Orchard, pp. 49-50): Omnipotens sempiterne deus, creator ac gubernator caeli et terrae, conditor et dispositor angelorum et hominum, rex regum et dominus dominorum, qui abraham fidelem famulum tuum de hostibus triumphare fecisti, moysi et iosuae populo tuo praelatis multiplicem uictoriam tribuisti, humilem quoque dauid puerum tuum regni fastigio sublimasti, eumque de ore leonis et de manu bestiae atque goliae, sed et de gladio maligno saul et omnium inimicorum eius liberasti, et salomonem sapientie pacisque ineffabili munere ditasti, respice propitius ad praeces nostrae humilitatis, et super hunc famulum tuum, quem supplici deuotione in regnum .N. albionis totius uidelicet francorum pariter eligimus, benedictionum tuarum dona multiplica, eumque dextera tuae potentiae semper ubique circumda, quatinus praedicti abrahe fidelitate firmatus, moysi mansuetudine fretus, iosue fortitudine munitus, dauid humilitate exaltatus, salomonis sapientia decoratus, tibi in omnibus complaceat, et per tramitem iustitiae inoffenso gressu semper incedat, et totius albionis ecclesiam deinceps cum plebibus sibi annexis ita enutriat, ac doceat, muniat, et instruat, contraque omnes uisibiles et inuisibiles hostes idem potenter regaliterque tuae uirtutis regimen amministret, ut regale solium uidelicet francorum sceptra non deserat, sed ad pristine fidei pacisque concordiam eorum animos te opitulante reformet, ut utrorumque horum populorum debita subiectione fultus, condigno amore glorificatus, per longum uitae spatium paternae apicem gloriae tua miseratione unatim stabilire et gubernare mereatur, tuae quoque protectionis galea munitus, et scuto insuperabili iugiter protectus, armisque caelestibus circumdatus, obtabilis uictoriae triumphum de hostibus feliciter capiat, terroremque suae potentiae infidelibus inferat, et pacem tibi militantibus laetanter reportet. Virtutibus necnon quibus praefatos fideles tuos decorasti, multiplici honoris benedictione condecora, et in regimine regni sublimiter colloca, et oleo gratiae spiritus sancti perunge.

478 See above, pp. 00-00/16-19.

479 See above, pp. 00-00/18-19. 


\section{Translation}

O almighty and everlasting God, creator and governor of heaven and earth, maker and ruler of angels and men, king of kings and lord of lords, who did cause your faithful servant Abraham to triumph over his enemies; did give many victories to Moses and Joshua, the leaders of your people; did also exalt your humble boy David to the height of a kingdom, and did save him from the lion's mouth and from the hand of the beast and of Goliath, and did also deliver him from the evil sword of Saul and of all his enemies; and did enrich Solomon with the unspeakable gift of wisdom and peace, graciously attend to our humble prayers, and multiply the gifts of your blessings over this your servant, whom in lowly devotion we do elect to the kingdom N. of all Albion, namely of the Franks equally, and always encircle him with the right hand of your power, that he, having been strengthened with the faith of the aforementioned Abraham, endued with the mildness of Moses, armed with the fortitude of Joshua, exalted with the humility of David, beautified with the wisdom of Solomon, may please you in all things, and may always walk with unhindered step along the path of justice, and may he in turn so nourish and teach, defend and instruct the church of all Albion with the people committed to his charge, and like a mighty king administer the rule of your power against all enemies, visible and invisible, that he should not abandon the royal throne namely the sceptres of the Franks, but by your help reform their minds to the concord of true faith and peace, that, strengthened with the due obedience and glorified with the condign love of both these peoples, he might deserve by your mercy through a lengthy span of life to establish and govern the apex of paternal glory unitedly; also defended with the helmet of your protection, continually protected with your invincible shield, and enclosed with heavenly armour, he might successfully seize the triumph of hoped-for victory from enemies, and inflict the terror of his power on infidels and joyfully bring peace to those that fight for you. Bestow on him the virtues, with which you have adorned your afore-mentioned servants, with the blessing of manifold honour, and set him on high in the rule of his kingdom, and anoint him with the oil of the grace of the Holy Spirit.

Other readings:

'SMN' manuscripts (Ward, 'An Early Version of the Anglo-Saxon Coronation Ceremony', pp. 352-3).

(a) ... in regnum pariter eligimus ...

(b) ... et totius regni ecclesiam ...

(c) ... ut regale solium uidelicet saxonum merciorum nordanhimbrorumque sceptra ...

(d) ... ut utrorumque horum populorum ...

Rouen, Bibliothèque municipale, Y.7 (369) ('Benedictional of Archbishop Robert'; New Minster, Winchester, s. $\left.\mathrm{xi}^{2 / 4}\right)$. Gneuss, Handlist, no. 923. Text: The Benedictional of Archbishop Robert, ed. H. A. Wilson, HBS 24 (London, 1903), 142.

(a) ... in regnum anglorum siue saxonum pariter eligimus ...

(b) ... et totius regni .N. eclesiam ...

(c) ... ut regale solium uidelicet anglorum uel saxonum sceptra ...

(d) ... ut populorum ... 
The Benedictional of Archbishop Robert preserves a variant of the B-version of the Second Ordo, slightly more schematic than the main B text; certain readings agree with Ratold and 'SMN' manuscripts against the main B text. ${ }^{480}$ The main B-version of the Second Ordo drew on an archetype of the A-version textually closer to Ratold than to 'SMN' manuscripts. ${ }^{481}$

The main B-version of the Second Ordo. Group I manuscripts (showing points of agreement with Claudius Pontifical II: see Robinson, 'The Coronation Order in the Tenth Century', p. 60):

London, British Library, Cotton Claudius A. iii, fols. 9-18 and 87-105 ('Claudius Pontifical II'; Christ Church, Canterbury, s. ximed). Gneuss, Handlist, no. 313. Text: Claudius Pontificals, ed. Turner, p. 91.

(a) ... in regem anglorum uel saxonum pariter eligimus ...

(b) ... Hic totius regni anglosaxonum aecclesiam ...

(c) ... ut regale solium uidelicet anglorum uel saxonum sceptra ...

(d) ... ut populorum ...

Douai, Bibliothèque municipale, 67 ('Douai Pontifical'; Winchester?, s. xii ${ }^{1 / 2}$ ). Hartzell, Catalogue of Manuscripts, p. 147 (no. 81). Text: variants noted in Liber pontificalis Chr. Bainbridge Archiepiscopi Eboracensis, ed. W. G. Henderson, Surtees Society 61 (Durham, 1875), p. xx; Three Coronation Orders, ed. J. Wickham Legg, HBS 19 (London, 1900), 1656.

(a)... in regem anglorum uel saxonum pariter eligimus ...

(b) ... Hic totius regni anglorum saxonum ecclesiam ...

(c) ... ut regale solium uidelicet anglorum uel saxonum sceptra ...

(c) ... ut populorum ...

Cambridge, Corpus Christi College 44 (Christ Church or St Augustine's, Canterbury, s. xi ${ }^{2 / 4}$ or s. $\mathrm{xi}^{3 / 4}$ ). Gneuss, Handlist, no. 40; Ker, Catalogue, p. 46 (no. 33). Text: Three Coronation Orders, ed. Wickham Legg, pp. 54-5 (an elaborated form of the B-version).

(a) ... in regem anglorum uel saxonum pariter eligimus ...

(b) ... hic domine quaesumus totius regni anglosaxonum aecclesiam ...

(c) ... in regale solium uidelicet anglorum uel saxonum sceptra ...

(d) ... atque populorum ...

480 Robinson, 'The Coronation Order in the Tenth Century', pp. 59-60; cf. also Ward, 'The Coronation Ceremony in Mediaeval England', pp. 167-70.

481 Ward, 'The Coronation Ceremony in Mediaeval England', p. 169, n. 7; Pratt, English Coronation Ordines. 
Group II manuscripts (readings in certain minor respects closer to the Benedictional of Archbishop Robert: see Robinson, 'The Coronation Order in the Tenth Century', p. 60):

Paris, Bibliothèque nationale de France, lat. 943 ('Pontifical of St Dunstan'; Christ Church, Canterbury, s. x ${ }^{2 / 2}$, after 960). Gneuss, Handlist, no. 879; Ker, Catalogue, pp. 437-9 (no. 364). Text: M. A. Conn, 'The Dunstan and Brodie (Anderson) Pontificals: an Edition and Study' (unpubl. PhD dissertation, Univ. of Notre Dame, 1993), pp. 116-17.

(a) ... in regnum anglorum uel saxonum pariter eligimus ...

(b) ... Hic totius regni ill. aecclesiam ...

(c) ... ut regale solium uidelicet anglorum uel saxonum sceptra ...

(d) ... ut populorum ...

London, British Library, Additional 57337 ('Anderson Pontifical'; Christ Church, Canterbury, s. x/xi). Gneuss, Handlist, no. 302. Text: Conn, 'The Dunstan and Brodie (Anderson) Pontificals', pp. 267-8.

(a) ... in regnum anglorum uel saxonum pariter eligimus ...

(b) ... Hic totius regni ill. aecclesiam ...

(c) ... ut regale solium uidelicet anglorum uel saxonum sceptra ...

(d)... ut populorum ...

Cambridge, Corpus Christi College 146 ('Samson Pontifical': Christ Church, Canterbury, s. xiin). Gneuss, Handlist, no. 46; Ker, Catalogue, pp. 50-1 (no. 37). Text: English Coronation Records, ed. Wickham Legg, pp. 16-17.

(a) ... in regnum anglorum uel saxonum pariter eligimus ...

(b) ... Hic totius regni .ill. ecclesiam ...

(c) ... ut regale solium uidelicet anglorum uel saxonum sceptra ...

(d) ... ut populorum ...

Reconstruction A: regard the 'SMN' and Ratold texts as preserving separate versions of the Second Ordo.

I. *Original version

(a) ... in regnum anglorum uel saxonum pariter eligimus ...

(b) ... et totius regni anglosaxonum ecclesiam ...

(c) ... ut regale solium uidelicet anglorum uel saxonum sceptra ...

(d) ... ut utrorumque horum populorum ...

The prayer as originally compiled was intended to apply to a king of 'both peoples', as reading (d), who may be identified as the 'Angles' and 'Saxons', as preserved in versions Va, $\mathrm{Vb}$ and Vc. Date: probably the mid to late 890 s. 
IIa. *Revised version

(a) ... in regnum pariter eligimus ...

(b) ... et totius regni ecclesiam ...

(c) ... ut regale solium uidelicet saxonum merciorum nordanhimbrorumque sceptra ...

(d) ... ut utrorumque horum populorum ...

As versions IVb and VII below ('SMN' manuscripts). A revised version intended to apply to a king of 'Saxons, Mercians and Northumbrians'. The overall scope of rule might suggest the reign of Æthelstan (924-39), after his takeover of Northumbria in 927, yet allowances should be made for the parallel with the title favoured in the later 'alliterative' charters, 'king of the Anglo-Saxons, Northumbrians, pagans and Britons'. This feature would suggest the 940s and 950s, and thus either the reign of Edmund (939-46) or the reign of Eadred (946-55).

Ilb. *Revised version

(a) ... in regnum albionis totius pariter eligimus ...

(b) ... et totius albionis ecclesiam ...

(c) ... ut regale solium uidelicet albionis sceptra ...

(d) ... ut utrorumque horum populorum ...

A revised version intended to apply to a king of 'Albion'. The hypothetical sequence would suggest a date after version IIa, yet prior to the drafting of the B-version, and therefore perhaps the 940 s or 950 s. The nomenclature might point specifically to the reign of Eadred (946-55), since rule over 'Albion' is a prominent feature of the 'Dunstan B' charters, first produced in the early $950 \mathrm{~s}$.

III. * Revised version

(a) ... in regnum pariter eligimus ...

(b) ... et totius regni ecclesiam ...

(c) ... ut regale solium uidelicet saxonum merciorum nordanhimbrorumque sceptra ...

(d) ... ut populorum ...

From version IIa: a hypothetical version in which 'utrorumque' was cancelled, to eliminate the apparent contradiction with reading (c).

IVa. *Version exported to Continent

As version IIb; exported in mid or later tenth century (before 986).

IVb. *Version exported to Continent

As version IIa above and version VII below ('SMN' manuscripts); exported in mid or later tenth century, or by early eleventh century at the latest. 
Va. Benedictional of Archbishop Robert

(a) ... in regnum anglorum siue saxonum pariter eligimus ...

(b) ... et totius regni .N. eclesiam ...

(c) ... ut regale solium uidelicet anglorum uel saxonum sceptra ...

(d) ... ut populorum ...

Ordo is a variant of the B-version of the Second Ordo. Anointing prayer readings: from version $\mathrm{I}$ (as $\mathrm{Vb}$ and $\mathrm{Vc}$ ) or from $\mathrm{Vb}$ or $\mathrm{Vc}$ ?

Vb. Claudius Pontifical II; cf. Douai Pontifical (and CCCC 44)

(a) ... in regem anglorum uel saxonum pariter eligimus ...

(b) ... et totius regni anglosaxonum ecclesiam ...

(c) ... ut regale solium uidelicet anglorum uel saxonum sceptra ...

(d) ... ut populorum ...

The main B-version of the Second Ordo (Group I manuscripts). Anointing prayer readings: from version I, but in knowledge of version III?

Vc. Pontifical of St Dunstan and Anderson Pontifical; cf. CCCC 146

(a) ... in regnum anglorum uel saxonum pariter eligimus ...

(b) ... Hic totius regni ill. aecclesiam ...

(c) ... ut regale solium uidelicet anglorum uel saxonum sceptra ...

(d) ... ut populorum ...

The main B-version of the Second Ordo (Group II manuscripts). Anointing prayer readings: from version I, but in knowledge of version III?

VI. Sacramentary of Ratold

(a) ... in regnum .N. albionis totius uidelicet francorum pariter eligimus ...

(b) ... et totius albionis ecclesiam ....

(c) ... ut regale solium uidelicet francorum sceptra ...

(d) ... ut utrorumque horum populorum ...

From version IVa: a partial attempt to disguise the Anglo-Saxon origin of the prayer, and adapt it for Frankish circumstances.

VII. 'SMN' manuscripts

(a) ... in regnum pariter eligimus ...

(b) ... et totius regni ecclesiam ...

(c) ... ut regale solium uidelicet saxonum merciorum nordanhimbrorumque sceptra ...

(d) ... ut utrorumque horum populorum ...

From version IVb. 
Reconstruction B: regard 'SMN' and Ratold texts as descending from a common English archetype, in which the references to 'Albion' and to 'Saxons, Mercians and Northumbrians' were combined.

\section{I. *Original version}

(a) ... in regnum anglorum uel saxonum pariter eligimus ...

(b) ... et totius regni anglosaxonum ecclesiam ...

(c) ... ut regale solium uidelicet anglorum uel saxonum sceptra ...

(d) ... ut utrorumque horum populorum ...

The prayer as originally compiled was intended to apply to a king of 'both peoples', as reading (d), who may be identified as the 'Angles' and 'Saxons', as preserved in versions Va, $\mathrm{Vb}$ and Vc. Date: probably the mid to late 890s.

\section{II. *Revised version}

(a) ... in regnum albionis totius pariter eligimus ...

(b) ... et totius albionis ecclesiam ...

(c) ... ut regale solium uidelicet saxonum merciorum nordanhimbrorumque sceptra ...

(d) ... ut utrorumque horum populorum ...

A revised version intended to apply to a king of 'Saxons, Mercians and Northumbrians' also claiming rule over 'Albion'. The overall scope of rule might suggest the reign of Æthelstan (924-39), after his takeover of Northumbria in 927, yet allowances should be made for the parallel with the title favoured in the later 'alliterative' charters, 'king of the Anglo-Saxons, Northumbrians, pagans and Britons'. This feature would suggest the 940s and 950s, and thus either the reign of Edmund (939-46) or the reign of Eadred (946-55); the combination of claims might point specifically to the reign of Eadred (946-55), since rule over 'Albion' is a prominent feature of the 'Dunstan B' charters, first produced in the early 950s.

III. *Revised version

(a) ... in regnum albionis totius pariter eligimus ...

(b) ... et totius albionis ecclesiam ...

(c) ... ut regale solium uidelicet saxonum merciorum nordanhimbrorumque sceptra ...

(d) ... ut populorum ...

From version II: a hypothetical version in which 'utrorumque' was cancelled, to eliminate the apparent contradiction with reading (c).

IVa. *Version exported to Continent

As version II; exported in mid or later tenth century (before 986). 
IVb. *Version exported to Continent

From version II; as employed to form version VII below ('SMN' manuscripts). Exported in mid or later tenth century, or by early eleventh century at the latest.

Va. Benedictional of Archbishop Robert

(a) ... in regnum anglorum siue saxonum pariter eligimus ...

(b) ... et totius regni .N. eclesiam ...

(c) ... ut regale solium uidelicet anglorum uel saxonum sceptra ...

(d) ... ut populorum ...

Ordo is a variant of the B-version of the Second Ordo. Anointing prayer readings: from version $\mathrm{I}$ (as $\mathrm{Vb}$ and $\mathrm{Vc}$ ) or from $\mathrm{Vb}$ or $\mathrm{Vc}$ ?

Vb. Claudius Pontifical II; cf. Douai Pontifical and CCCC 44

(a) ... in regem anglorum uel saxonum pariter eligimus ...

(b) ... et totius regni anglosaxonum ecclesiam ...

(c) ... ut regale solium uidelicet anglorum uel saxonum sceptra ...

(d) ... ut populorum ...

The main B-version of the Second Ordo (Group I manuscripts). Anointing prayer readings: from version I, but in knowledge of version III?

Vc. Pontifical of St Dunstan and Anderson Pontifical; cf. CCCC 146

(a) ... in regnum anglorum uel saxonum pariter eligimus ...

(b) ... Hic totius regni ill. aecclesiam ...

(c) ... ut regale solium uidelicet anglorum uel saxonum sceptra ...

(d) ... ut populorum ...

The main B-version of the Second Ordo (Group II manuscripts). Anointing prayer readings: from version I, but in knowledge of version III?

VI. Sacramentary of Ratold

(a) ... in regnum albionis totius uidelicet francorum pariter eligimus ...

(b) ... et totius albionis ecclesiam ....

(c) ... ut regale solium uidelicet francorum sceptra ...

(d) ... ut utrorumque horum populorum ...

From version IVa: a partial attempt to disguise the Anglo-Saxon origin of the prayer, and adapt it for Frankish circumstances.

VII. 'SMN' manuscripts 

(a) ... in regnum pariter eligimus ...
(b) ... et totius regni ecclesiam ...
(c) ... ut regale solium uidelicet saxonum merciorum nordanhimbrorumque sceptra ...
(d) ... ut utrorumque horum populorum ...

From version IVb: the cancellation of 'albion' in readings (a) and (b), if this occurred in a Continental context, might be understood as a further partial attempt to disguise the AngloSaxon origin of the prayer, and adapt it for Frankish circumstances. 
The anointing prayer of the Second Ordo, Omnipotens sempiterne deus, is also central to the question of the origins of the Ordo, since certain sections show textual proximity to Omnipotens sempiterne deus of the Erdmann Ordo, while others are close to Omnipotens eterne deus, the anointing prayer of the Ordo of Seven Forms; the latter prayer also occurs in a variant form in the Leiden Ordo. The table below lays out the respective prayers, and indicates the form of textual relationship for which a detailed case has been advanced. ${ }^{482}$ The English prayer appears to have been derived from two sources: Omnipotens sempiterne deus of the Erdmann Ordo, which provided the bulk of the text, and Omnipotens aeterne deus of the Leiden Ordo, which provided the section in the middle of the prayer, including the references to kingship over two peoples. The Second Ordo text is that of the Sacramentary of Ratold, providing for a king ruling over 'Albion'; for a reconstruction of what appears to have been the earliest version of the text, representing the king as ruling over 'Angles' and 'Saxons', see Table 1. Underlined text indicates the source being followed by the compiler of the Second Ordo; text emboldened in the Second Ordo version of the prayer indicates departures from the source. The corresponding prayer in the Ordo of Seven Forms is included for comparison; the closer relationship of the Leiden text may be here observed.

482 See above, pp. 00-00/28-35. Cf. Lanoè, 'L'ordo de couronnement', pp. 65-8. 


\begin{tabular}{|c|c|c|c|}
\hline $\begin{array}{l}\text { Erdmann Ordo } \\
\text { (Ordines, ed. } \\
\text { Jackson, p. 148) }\end{array}$ & $\begin{array}{l}\text { Leiden } \text { Ordo (ed. } \\
\text { Lanoè, pp. 61-2: cf. } \\
\text { also } \\
\text { Ordines, ed. } \\
\text { Jackson, pp. 159- } \\
\text { 61, MS A) }\end{array}$ & $\begin{array}{l}\text { Ordo of Seven } \\
\text { Forms (Ordines, } \\
\text { ed. Jackson, pp. } \\
\text { 159-61, MS E) }\end{array}$ & $\begin{array}{l}\text { A-version of the } \\
\text { Second Ordo } \\
\text { (Sacramentary of } \\
\text { Ratoldus, ed. } \\
\text { Orchard, pp. 49-50) }\end{array}$ \\
\hline 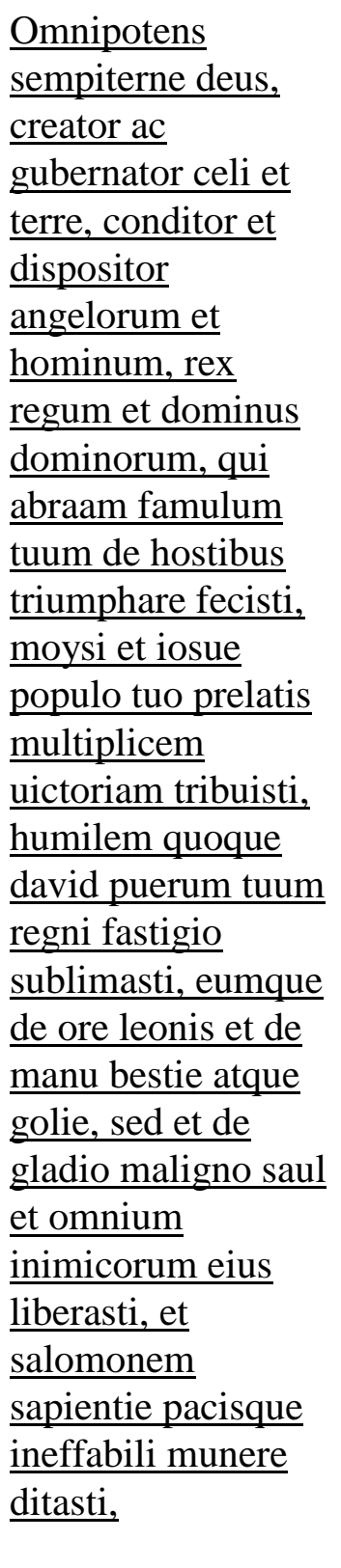 & $\begin{array}{l}\text { Omnipotens } \\
\text { aeterne deus creator } \\
\text { omnium. imperator } \\
\text { angelorum. rex } \\
\text { regnantium. } \\
\text { dominus } \\
\text { dominantium. qui } \\
\text { abraham fidelem } \\
\text { famulum tuum de } \\
\text { hostibus triumphare } \\
\text { fecisti. moysi et } \\
\text { iosuae populo tuo } \\
\text { praelatis. } \\
\text { multiplicem } \\
\text { uictoriam tribuisti. } \\
\text { humilemque dauid } \\
\text { puerum tuum regni } \\
\text { fastigio sublimasti. } \\
\text { et salomonem } \\
\text { sapientiae pacisque } \\
\text { ineffabili munere } \\
\text { ditasti. }\end{array}$ & $\begin{array}{l}\text { Omnipotens eterne } \\
\text { deus, creator } \\
\text { omnium, imperator } \\
\text { angelorum, rex } \\
\text { regnantium } \\
\text { dominusque } \\
\text { dominantium, qui } \\
\text { habraham fidelem } \\
\text { famulum tuum de } \\
\text { hostibus triumphare } \\
\text { fecisti, moysi et } \\
\text { iosue populo } \\
\text { prelatis } \\
\text { multiplicem } \\
\text { uictoriam tribuisti, } \\
\text { humilemque david } \\
\text { puerum tuum regni } \\
\text { fastigio sublimasti, } \\
\text { et salomonem } \\
\text { sapientie pacisque } \\
\text { ineffabili munere } \\
\text { ditasti, }\end{array}$ & $\begin{array}{l}\text { Omnipotens } \\
\text { sempiterne deus. } \\
\text { creator ac } \\
\text { gubernator caeli et } \\
\text { terrae, conditor et } \\
\text { dispositor } \\
\text { angelorum et } \\
\text { hominum, rex } \\
\text { regum et dominus } \\
\text { dominorum, qui } \\
\text { abraham fidelem } \\
\text { famulum tuum de } \\
\text { hostibus triumphare } \\
\text { fecisti, moysi et } \\
\text { iosuae populo tuo } \\
\text { praelatis } \\
\text { multiplicem } \\
\text { uictoriam tribuisti, } \\
\text { humilem quoque } \\
\text { dauid puerum tuum } \\
\text { regni fastigio } \\
\text { sublimasti, eumque } \\
\text { de ore leonis et de } \\
\text { manu bestiae atque } \\
\text { goliae, sed et de } \\
\text { gladio maligno saul } \\
\text { et omnium } \\
\text { inimicorum eius } \\
\text { liberasti, et } \\
\text { salomonem } \\
\text { sapientie pacisque } \\
\text { ineffabili munere } \\
\text { ditasti, }\end{array}$ \\
\hline
\end{tabular}




\begin{tabular}{|c|c|c|c|}
\hline $\begin{array}{l}\text { respice, } \\
\text { quaesumus, ad } \\
\text { preces humilitatis } \\
\text { nostre, et hunc } \\
\text { famulum tuum .ill. }\end{array}$ & 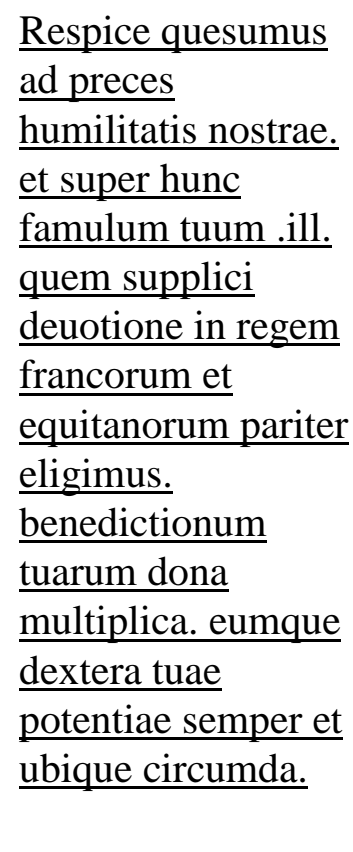 & $\begin{array}{l}\text { respice, quesumus, } \\
\text { ad preces } \\
\text { humilitatis nostre et } \\
\text { super hunc } \\
\text { famulum tuum .N., } \\
\text { quem suplici } \\
\text { devotione in regem } \\
\text { eligimus, } \\
\text { benedictionum } \\
\text { tuarum dona in eo } \\
\text { multiplica eumque } \\
\text { dextera tue potentie } \\
\text { semper et ubique } \\
\text { circumda, }\end{array}$ & $\begin{array}{l}\text { respice propitius } \\
\text { ad praeces nostrae } \\
\text { humilitatis. et super } \\
\text { hunc famulum } \\
\text { tuum, quem } \\
\text { supplici deuotione } \\
\text { in regnum .N. } \\
\text { albionis totius } \\
\text { uidelicet } \\
\text { francorum pariter } \\
\text { eligimus, } \\
\text { benedictionum } \\
\text { tuarum dona } \\
\text { multiplica, eumque } \\
\text { dextera tuae } \\
\text { potentiae semper } \\
\text { ubique circumda, }\end{array}$ \\
\hline
\end{tabular}




\begin{tabular}{|c|c|c|}
\hline \\
\hline abrahae fidelitate & habrae fidelitate & abrahe fidelitate \\
\hline firmatus. moysi & firmatus, moysi & firmatus, moysi \\
\hline mansuetudine & mansuetudine & mansuetudine \\
\hline fretus. iosuae & fretus, iosue & fretus, iosue \\
\hline fortitudine munitus & fortitudine munitus, & fortitudine munitus, \\
\hline dauid humilitate & david humilitate & dauid humilitate \\
\hline ral & exalt & exalt \\
\hline salomonis sapientia & salomonis sapientia & salomonis sapientia \\
\hline $\begin{array}{l}\text { decoratus. tibi in } \\
\underline{\text { omnibus }}\end{array}$ & $\begin{array}{l}\text { decoratus, tibi in } \\
\text { omnibus placeat et }\end{array}$ & $\begin{array}{l}\text { decoratus, tibi in } \\
\text { omnibus }\end{array}$ \\
\hline complac & per tramitem & complaceat, et per \\
\hline tramitem iustitiae & iustitie inoffenso & tramitem iustitiae \\
\hline inoffenso gressu & gressu semper & inoffenso gressu \\
\hline semper incedat. & incedat, & semper incedat, et \\
\hline Ecclesiamque & ecclesiamque tuam & totius albionis \\
\hline$\overline{\text { ecquitanam et }}$ & deinceps cum & ecclesiam deinceps \\
\hline einceps & plebibus sibi & cum plebibus sibi \\
\hline cum plebibus sibi & annexis ita enutriat & annexis ita enutriat, \\
\hline$\frac{\text { adnexis ita enutriat. }}{\text { ac doceat. muniat. }}$ & $\begin{array}{l}\text { ac doceat, muniat et } \\
\text { instruat, contraque }\end{array}$ & $\begin{array}{l}\text { ac doceat, muniat, } \\
\text { et instruat, }\end{array}$ \\
\hline et instruat. & omnes uisibiles et & contraque omnes \\
\hline e omnes & inuisibiles hostes & uisibiles et \\
\hline uisibiles. et & eidem potenter & inuisibiles hostes \\
\hline inuisibiles hostes. & regaliterque tue & idem potenter \\
\hline tenter & s regimen & regaliterque tuae \\
\hline regaliterque tuae & administret & uirtutis regimen \\
\hline uirtutis regimen & & amministret, ut \\
\hline tret. ut & & regale solium \\
\hline francorum regnum & ere fidei & uidelicet francorum \\
\hline non deserat. sed ad & pacis & sceptra non \\
\hline pristine fidei & concordiam eorum & deserat, sed ad \\
\hline pacis & animos te & pristine fidei \\
\hline concordiam eorum & opitulante reformet, & pacisque \\
\hline anim & ut horum & concordiam eorum \\
\hline opitulante reformet. & populorum debita & animos te \\
\hline ut utrorumque & subiectione fultus, & opitulante reformet, \\
\hline opulorum & cum digno amore & ut utrorumque \\
\hline debita subiectione & glorificetur, [et] ad & horum populorum \\
\hline fultus. condi & paternum decenter & debita subiectione \\
\hline amore glorificatus & solium tua & fultus, condigno \\
\hline ad pa & miseratione & amore glorificatus, \\
\hline decenter solium tua & conscendere & per longum uitae \\
\hline miseratione & mereatur, & spatium paternae \\
\hline conscendere & & apicem gloriae tua \\
\hline mereatur. & & $\begin{array}{l}\text { miseratione unatim } \\
\text { stabilire et } \\
\text { gubernare } \\
\text { mereatur, }\end{array}$ \\
\hline
\end{tabular}


uirtutibus quibus

\begin{tabular}{|c|c|c|}
\hline 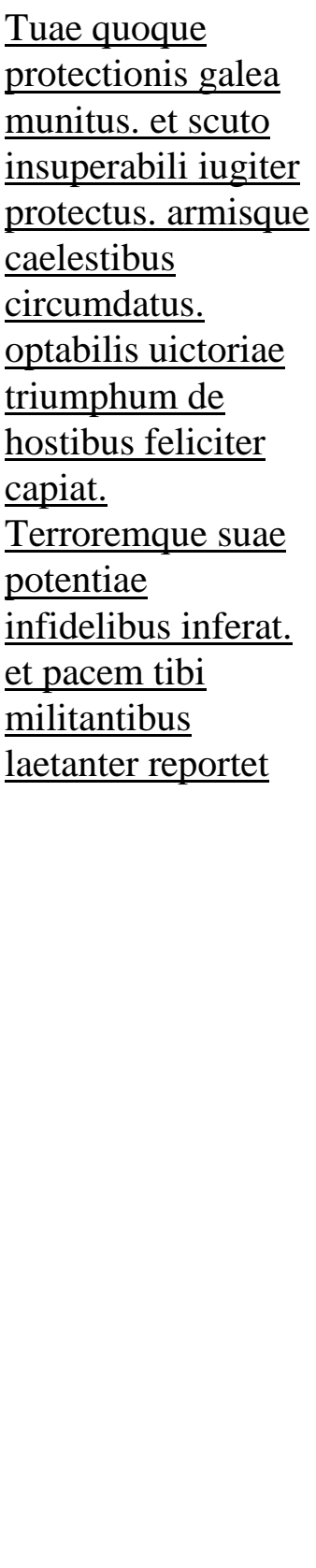 & $\begin{array}{l}\text { tue quoque } \\
\text { protectionis galea } \\
\text { munitus et scuto } \\
\text { insuperabili iugiter } \\
\text { protectus armisque } \\
\text { celestibus } \\
\text { circumdatus, } \\
\text { optabilis uictorie } \\
\text { triumphum fideliter } \\
\text { uel feliciter capiat } \\
\text { terroremque sue } \\
\text { potentie infidelibus } \\
\text { inferat et pacem } \\
\text { tibi militantibus } \\
\text { letanter reportet, }\end{array}$ & $\begin{array}{l}\text { Virtutibus necnon } \\
\text { quibus praefatos } \\
\text { fideles tuos } \\
\text { decorasti. } \\
\text { multiplici honoris } \\
\text { benedictione } \\
\text { condecora. et in } \\
\text { regimine regni } \\
\text { sublimiter colloca. } \\
\text { et oleo gratiae } \\
\text { spiritus sancti } \\
\text { perunge. } \\
\text { [anointing, } \\
\text { followed by the } \\
\text { antiphon Vnxerunt } \\
\text { Salomonem] }\end{array}$ \\
\hline
\end{tabular}


unde unxisti

sacerdotes, reges,

prophetas et

martyres, qui per

fidem uicerunt

regna et operati

sunt iustitiam atque

adepti sunt

promissiones.

Huius sacratissima

unctio super caput

eius defluat atque

ad interiora eius

descendat et cordis

illius intima

penetret, et

promissionibus,

quas adepti sunt

uictoriosissimi

reges, gratia tua

dignus efficiatur,

quatinus et in

presenti seculo

feliciter regnet et

ad eorum

consortium in

celesti regno

perveniat. Per

dominum nostrum

iesum christum

filium tuum, qui

unctus est oleo

letitie pre

consortibus suis et

uirtute crucis

potestates aerias

debellauit, tartara

destruxit

regnumque diaboli

superauit et ad

celos uictor

ascendit, in cuius

manu uictoria

omnis, gloria et

potestas consistunt,

et tecum uiuit et

regnat deus in

unitate eiusdem

spiritus sancti per

omnia secula

seculorum. Amen.
Vnde unxisti

sacerdotes reges, et

prophetas, ac

martyres, qui per

fidem uicerunt

regna et operati

sunt iustitiam,

atque adempti sunt

promissiones.

Cuius sacratissima

unctio super caput

eius defluat, atque

ad interiora

descendat, et cordis

illius intima

penetret, et

promissionibus

quas adempti sunt

uictoriosissimi

reges, gratia tua

dignus efficiatur,

quatinus et in

praesenti saeculo

feliciter regnet, et

ad eorum

consortium in

caelesti regno

perueniat, per

dominum nostrum

ihesum christum

filium tuum, qui

per christum

per dominum

unctus est oleo

dominum nostrum.

nostrum, qui uirtute

laetitiae prae

Qui uirtute crucis

crucis tartara

consortibus suis. et

destruxit, regnoque

diaboli superato ad

celos ascendit, in

quo potestas omnis

regumque consistit

uictoria, qui est

gloria humilium et

uita salusque

populorum. Qui

tecum uiuit et

regnat deus in

unitate spiritus

uirtute crucis

potestates aereas

debellauit, tartara

destruxit.

regnumque diaboli

superauit, et ad

caelos uictor

ascendit, in cuius

manu uictoria,

omnis gloria et

potestas consistunt, et tecum uiuit et regnat deus in unitate eiusdem spiritus. Per. 


\section{Translations}

Erdmann Ordo: $\mathrm{O}$ almighty and everlasting God, creator and governor of heaven and earth, maker and ruler of angels and men, king of kings and lord of lords, who did cause your faithful servant Abraham to triumph over his enemies; did give many victories to Moses and Joshua, the leaders of your people; did also exalt your humble boy David to the height of a kingdom, and did save him from the lion's mouth and from the hand of the beast and of Goliath, and did also deliver him from the evil sword of Saul and of all his enemies; and did enrich Solomon with the unspeakable gift of wisdom and peace, attend, we beseech, to our humble prayers, and bestow on this your servant $\mathrm{N}$. the virtues, with which you have adorned your afore-mentioned servants, with the blessing of manifold honour, and set him on high in the rule of his kingdom, and anoint him with the oil of the grace of the Holy Spirit, wherefore you did anoint priests, kings, prophets and martyrs, who through faith conquered kingdoms and brought justice, and obtained promises. May the most sacred unction flow upon his head and descend inwards and penetrate the most hidden parts of his heart; and may he by your grace be worthy of the promises which the most victorious kings obtained, that in this present life he may reign happily, and finally attain fellowship with them in the heavenly kingdom, through our Lord Jesus Christ your son, who was anointed with the oil of gladness above his fellows, and by the power of the cross defeated the demons of the air, destroyed hell and overcame the realm of the devil, and ascended victorious into heaven, in whose hand all victory, glory and power remains, and who lives and reigns in the unity of the Holy Spirit, one God world without end.

Leiden Ordo: $\mathrm{O}$ almighty and everlasting God, creator of all, ruler of angels, king of kings and lord of lords, who did cause your faithful servant Abraham to triumph over his enemies; did give many victories to Moses and Joshua, the leaders of your people; did exalt your humble boy David to the height of a kingdom; and did enrich Solomon with the unspeakable gift of wisdom and peace, attend, we beseech, to our humble prayers, and multiply the gifts of your blessings over this your servant N., whom in lowly devotion we do elect as king of the Franks and Aquitanians equally, and always encircle him with the right hand of your power, that he, having been strengthened with the faith of the afore-mentioned Abraham, endued with the mildness of Moses, armed with the fortitude of Joshua, exalted with the humility of David, beautified with the wisdom of Solomon, may please you in all things, and may always walk with unhindered step along the path of justice, and may he in turn so nourish and teach, defend and instruct the church in Aquitaine and Francia with the people committed to his charge, and like a mighty king administer the rule of your power against all enemies, visible and invisible, that he should not abandon the kingdom of the Franks, but by your help reform their minds to the concord of true faith and peace, that, strengthened with the due obedience and glorified with the condign love of both these peoples, he might deserve by your mercy to proceed fittingly to the paternal throne; also defended with the helmet of your protection, continually protected with your invincible shield, and enclosed with heavenly armour, he might successfully seize the triumph of hoped-for victory from enemies, and inflict the terror of his power on infidels and joyfully bring peace to those that fight for you, through Christ our Lord, who by the power of the cross destroyed hell and, having overcome the realm of the devil, ascended victorious into heaven, in whom all power and the victory of kings remains, who is the glory of the humble and the life and salvation of peoples, who lives and reigns with you in the unity of the Holy Spirit, one God world without end. Amen. 
Ordo of Seven Forms: O almighty and everlasting God, creator of all, ruler of angels, king of kings and lord of lords, who did cause your faithful servant Abraham to triumph over his enemies; did give many victories to Moses and Joshua, the leaders of your people; did exalt your humble boy David to the height of a kingdom; and did enrich Solomon with the unspeakable gift of wisdom and peace, attend, we beseech, to our humble prayers, and multiply the gifts of your blessings over this your servant N., whom in lowly devotion we do elect as king, and always encircle him with the right hand of your power, that he, having been strengthened with the faith of the afore-mentioned Abraham, endued with the mildness of Moses, armed with the fortitude of Joshua, exalted with the humility of David, beautified with the wisdom of Solomon, may please you in all things, and may always walk with unhindered step along the path of justice, and may he in turn so nourish and teach, defend and instruct your church with the people committed to his charge, and like a mighty king administer the rule of your power against all enemies, visible and invisible, and by your help reform their minds to the concord of true faith and peace, that, strengthened with the due obedience he might be glorified with the condign love of these peoples, and might deserve by your mercy to proceed fittingly to the paternal throne; also defended with the helmet of your protection, continually protected with your invincible shield, and enclosed with heavenly armour, he might faithfully and successfully seize the triumph of hoped-for victory from enemies, and inflict the terror of his power on infidels and joyfully bring peace to those that fight for you, through our Lord, who by the power of the cross destroyed hell and, having overcome the realm of the devil, ascended into heaven, in whom all power and the victory of kings remains, who is the glory of the humble and the life and salvation of peoples, who lives and reigns with you, one God in the unity of the Holy Spirit.

A-version of the Second Ordo: O almighty and everlasting God, creator and governor of heaven and earth, maker and ruler of angels and men, king of kings and lord of lords, who did cause your faithful servant Abraham to triumph over his enemies; did give many victories to Moses and Joshua, the leaders of your people; did also exalt your humble boy David to the height of a kingdom, and did save him from the lion's mouth and from the hand of the beast and of Goliath, and did also deliver him from the evil sword of Saul and of all his enemies; and did enrich Solomon with the unspeakable gift of wisdom and peace, graciously attend to our humble prayers, and multiply the gifts of your blessings over this your servant, whom in lowly devotion we do elect to the kingdom N. of all Albion, namely of the Franks equally, and always encircle him with the right hand of your power, that he, having been strengthened with the faith of the afore-mentioned Abraham, endued with the mildness of Moses, armed with the fortitude of Joshua, exalted with the humility of David, beautified with the wisdom of Solomon, may please you in all things, and may always walk with unhindered step along the path of justice, and may he in turn so nourish and teach, defend and instruct the church of all Albion with the people committed to his charge, and like a mighty king administer the rule of your power against all enemies, visible and invisible, that he should not abandon the royal throne namely the sceptres of the Franks, but by your help reform their minds to the concord of true faith and peace, that, strengthened with the due obedience and glorified with the condign love of both these peoples, he might deserve by your mercy through a lengthy span of life to establish and govern the apex of paternal glory unitedly; also defended with the helmet of your protection, continually protected with your invincible shield, and enclosed with heavenly armour, he might successfully seize the triumph of hoped-for victory from enemies, and inflict the terror of his power on infidels and joyfully bring peace to those that fight for you. Bestow on him the virtues, with which you have adorned your afore-mentioned 
servants, with the blessing of manifold honour, and set him on high in the rule of his kingdom, and anoint him with the oil of the grace of the Holy Spirit.

Wherefore you did anoint priests, kings and prophets and martyrs, who through faith conquered kingdoms and brought justice, and obtained promises. May your most sacred unction flow upon his head and descend inwards and penetrate the most hidden parts of his heart; and may he by your grace be worthy of the promises which the most victorious kings obtained, that in this present life he may reign happily, and finally attain fellowship with them in the heavenly kingdom, through our Lord Jesus Christ your son, who was anointed with the oil of gladness above his fellows, and by the power of the cross defeated the demons of the air, destroyed hell and overcame the realm of the devil, and ascended victorious into heaven, in whose hand all victory, glory and power remains, and who lives and reigns with you in the unity of the Holy Spirit, one God world without end. 
The A-version of the Second Ordo appears to have drawn principally on three sources: the First English Ordo, the Erdmann Ordo and the Leiden Ordo. ${ }^{483}$ In addition to the three main sources, the compiler also appears to have had access to certain elements of the Ordo used for the anointing of Charles the Bald in 869.484 The table below lays out the relationship which has been discerned to these probable sources. The forthcoming edition of the A-version, in Pratt, English Coronation Ordines, aligns the Ratold text with the relevant source-texts. For the First Ordo, the compiler had a text aligned with the tradition represented by the Ecgberht and Lanalet Pontificals. The formula Deus qui populis, present in the Lanalet Pontifical, probably represented a later borrowing from the Second Ordo and has therefore been omitted below. For clarity, the Mass settings in the First Ordo, Erdmann and the Second Ordo have also been omitted. Underlined text indicates the formulas and elements used or drawn upon in the Second Ordo.

\begin{tabular}{|c|c|c|c|}
\hline $\begin{array}{l}\text { First Ordo } \\
\text { (Pontificale } \\
\text { Lanaletense, ed. } \\
\text { Doble, pp. 60-3) }\end{array}$ & $\begin{array}{l}\text { Erdmann Ordo } \\
\text { (Ordines, ed. } \\
\text { Jackson, pp. 147- } \\
\text { 52) }\end{array}$ & $\begin{array}{l}\text { Leiden Ordo (ed. } \\
\text { Lanoè, pp. 61-4: cf. } \\
\text { also } \\
\text { Ordines, ed. } \\
\text { Jackson, pp. 159- } \\
\text { 64, MS A) }\end{array}$ & $\begin{array}{l}\text { A-version of the } \\
\text { Second Ordo } \\
\text { (Sacramentary of } \\
\text { Ratoldus, ed. } \\
\text { Orchard, pp. 47-55) } \\
\text { [with probable } \\
\text { source] }\end{array}$ \\
\hline & $\begin{array}{l}\text { King's } \text { ordo } \\
\text { Petition of bishops } \\
\text { A uobis perdonari } \\
\underline{\text { petimus }} \\
\text { Response of king } \\
\underline{\text { Promitto uobis et }} \\
\underline{\text { perdono }} \\
\text { Enquiry of bishops } \\
\text { to people } \\
\underline{\text { Te deum }}\end{array}$ & & $\begin{array}{l}\text { King's } \text { ordo } \\
\text { Petition of bishops } \\
\text { A uobis perdonari } \\
\text { petimus } \\
\text { Response of king } \\
\text { Promitto uobis et } \\
\text { perdono } \\
\text { Enquiry of bishops } \\
\text { to people } \\
\text { Te deum } \\
\text { [all Erdmann] } \\
\text { King's prostration }\end{array}$ \\
\hline $\begin{array}{l}\text { Benedictions } \\
\text { Te inuocamus } \\
\end{array}$ & $\begin{array}{l}\text { Benedictions } \\
\text { Deus qui populis }\end{array}$ & & $\begin{array}{l}\text { Benedictions } \\
\text { Te inuocamus } \\
\text { [First Ordo] } \\
\text { Deus qui populis } \\
\text { [Erdmann] }\end{array}$ \\
\hline
\end{tabular}


Anointing
Antiphon:
Vncxerunt
Salomonem
Psalm: Domine in
uirtute tua

$\underline{\text { Deus electorum }}$

Sceptre

Benedic domine

hunc presulem

Deus cuius est

omnis potestas

Staff (baculus)

Omnipotens det tibi deus

Sword

Accipe hunc

gladium
Anointing
Omnipotens
aeterne deus

$\underline{\text { Deus dei filius }}$

Ring

Accipe anulum
Helmet

Benedic domine

fortitudinem

principis

\begin{abstract}
Crown
Coronet te dominus corona glorie
\end{abstract}

Omnium domine fons bonorum
Anointing

Omnipotens

sempiterne deus

[fusion of Erdmann and Leiden: see above, pp. 00-

00/28-35 and 00-

00/93-101]

Antiphon:

Vnxerunt

Salomonem

[First Ordo]

Deus electorum

[First Ordo]

Deus dei filius

[Leiden]

Ring

Accipe anulum

[adapted from

Erdmann]

Deus cuius est

omnis potestas

[Erdmann]

Sword

Accipe hunc

gladium

[Erdmann]

Deus qui

prouidentia tua

[First Ordo -

preface of the

Mass]

Crown

Coronet te deus corona glorie

[Erdmann]

Deus perpetuitatis [adapted from First Ordo plus anointing prayer of 869] 
Sceptre

Accipe sceptrum

Staff (baculus)

Accipe baculum

Sceptre

Accipe uirgam

Enthronement

Sta et retine

Viuat rex.N. in

sempiternum

Enthronement

Benediction

Deus perpetuitatis

Three precepts

Rectitudo regis est
Sceptre

Accipe sceptrum

[Erdmann]

Omnium domine

fons bonorum

[Erdmann]

Rod (uirga)

Accipe uirgam

[Leiden]

Benedictions

Extendat

omnipotens deus

dexteram

[adapted from

Hincmar's

blessing, anointing

prayer and Et qui te

uoluit of 869]

Benedic domine

hunc praesulem

[First Ordo]

Enthronement

Sta et retine

[Leiden]

Three precepts

Rectitudo regis est

[First Ordo]

Acclamation

Viuat rex feliciter

in sempiternum

[First Ordo]

Mass continues [cf. setting of First

Ordo within Mass]

Queen's ordo

Queen's prostration

[Erdmann]

Benediction

Adesto domine

[Erdmann] 
Anointing

Omnipotens

sempiterne deus

Ring

Accipe anulum

Deus cuius est

omnis potestas

Crown

Accipe coronam

glorie

Omnipotens

sempiterne deus

fons et origo

omnium bonorum
Anointing

Omnipotens

sempiternae deus

[adapted from

Erdmann]

Ring

Accipe anulum

[Erdmann]

Deus cuius est

omnis potestas

[Erdmann]

\section{Crown}

Accipe coronam

gloriae [Erdmann]

Omnium domine

fons bonorum

[adapted from

Erdmann] 